\title{
Homology Model and Ligand Binding Interactions of the Extracellular Domain of the Human $\alpha 4 \beta 2$ Nicotinic Acetylcholine Receptor
}

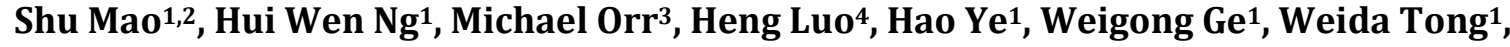 \\ Huixiao Hong ${ }^{*}$ \\ ${ }^{1}$ Division of Bioinformatics and Biostatistics, National Center for Toxicological Research, U.S. Food and Drug \\ Administration, Jefferson, AR, USA \\ ${ }^{2}$ School of Pharmacy and Bioengineering, Chongqing University of Technology, Chongqing, China \\ ${ }^{3}$ Division of Nonclinical Science, Office of Science, Center for Tobacco Products, U.S. Food and Drug \\ Administration, Silver Spring, MD, USA \\ ${ }^{4}$ Division of Systems Biology, National Center for Toxicological Research, U.S. Food and Drug Administration, \\ Jefferson, AR, USA \\ Email: "huixiao.hong@fda.hhs.gov
}

Received 5 November 2015; accepted 24 January 2016; published 28 January 2016

Copyright (C) 2016 by authors and Scientific Research Publishing Inc.

This work is licensed under the Creative Commons Attribution International License (CC BY). http://creativecommons.org/licenses/by/4.0/

(c) (1) Open Access

\section{Abstract}

Addiction to nicotine, and possibly other tobacco constituents, is a major factor that contributes to the difficulties smokers face when attempting to quit smoking. Amongst the various subtypes of nicotinic acetylcholine receptors (nAChRs), the $\alpha 4 \beta 2$ subtype plays an important role in mediating the addiction process. The characterization of human $\alpha 4 \beta 2$-ligand binding interactions provides a molecular framework for understanding ligand-receptor interactions, rendering insights into mechanisms of nicotine addiction and may furnish a tool for efficiently identifying ligands that can bind the nicotine receptor. Therefore, we constructed a homology model of human $\alpha 4 \beta 2 \mathrm{nAChR}$ and performed molecular docking and molecular dynamics (MD) simulations to elucidate the potential human $\alpha 4 \beta 2$-ligand binding modes for eleven compounds known to bind to this receptor. Residues V96, L97 and F151 of the $\alpha 4$ subunit and L111, F119 and F121 of the $\beta 2$ subunit were found to be involved in hydrophobic interactions while residues $S 153$ and W154 of the $\alpha 4$ subunit were involved in the formation of hydrogen bonds between the receptor and respective ligands. The homology model and its eleven ligand-bound structures will be used to develop a virtual screening program for identifying tobacco constituents that are potentially addictive.

\footnotetext{
*Corresponding author.
}

How to cite this paper: Mao, S., Ng, H.W., Orr, M., Luo, H., Ye, H., Ge, W., Tong, W. and Hong, H. (2016) Homology Model and Ligand Binding Interactions of the Extracellular Domain of the Human $\alpha 462$ Nicotinic Acetylcholine Receptor. J. Biomedical Science and Engineering, 9, 41-100. http://dx.doi.org/10.4236/jbise.2016.91005 


\section{Keywords}

\section{Nicotinic Acetylcholine Receptors, Homology Model, Ligand-Receptor Interactions}

\section{Introduction}

Most smokers continue tobacco use because of their nicotine addiction despite of the well-known adverse health consequences. Of the more than 40 million smokers in the United States, more than $70 \%$ of smokers express a desire to quit smoking [1]. Only 3\% of smokers who made a quit attempt in the past year were successful [2] [3].

Nicotine from inhaled smoke rapidly moves into the brain to exert its actions by binding to neuronal nicotinic acetylcholine receptors (nAChRs), which are members of the Cys-loop family of ligand-gated ion channels [4]. To date, 12 neuronal-type nAChR subunits $(\alpha 2-\alpha 10, \beta 2-\beta 4)$ which can assemble into functional heteromeric or homomeric ( $\alpha$-subunit only) pentamers have been identified [4]-[6]. In the mammalian brain, the $\alpha 4 \beta 2$ subtypeisone of the most commonly found nAChRs [7] [8]. It plays important roles in mediating the nicotine reward and addiction process and has been targeted for nicotine addiction treatment [9]. The pocket of $\alpha 4 \beta 2 \mathrm{nAChR}$, to which various ligands can bind, is situated at the interface of the primary $\alpha 4$ subunit and the complementary $\beta 2$ subunit [10] [11]. Understanding the molecular interactions between $\alpha 4 \beta 2 \mathrm{nAChR}$ and its ligands could assist development of virtual screening of tobacco constituents with addiction potential through human $\alpha 4 \beta 2 \mathrm{nAChR}$ binding. The three-dimensional (3D) structure of the receptor and its dynamic molecular properties are the key for elucidation of the molecular interactions [12]. However, the 3D structure of a human $\alpha 4 \beta 2 \mathrm{nAChR}$ has yet to be experimentally determined. On the other hand, the 3D crystal structures of acetylcholine binding proteins (AChBPs) from Lymnaea stagnalis (Ls) [13], Aplysia californica (Ac) [14], and annelid Capitella teleta (Ct) have been experimentally determined [15] [16]. These AChBPs are structurally similar to the extracellular ligand-binding domain (LBD) of human AChRs and thus serve as an important surrogate for the study of nAChRs. Based on the template of these AChBP X-ray structures, homology structures of the human $\alpha 4 \beta 2$ receptor have previously been constructed using the 3D crystal structure data for the AChBPs [11] [17] [18], although this information has not been made available to the scientific community.

In this study, we constructed a 3D homology model of the extracellular domain of the human $\alpha 4 \beta 2 \mathrm{nAChR}$ (hereafter referred to as human $\alpha 4 \beta 2 \mathrm{nAChR}$ ) using the X-ray crystal structure of Ct-AChBP that was determined at a high resolution [19]. The homology structure of human $\alpha 4 \beta 2 \mathrm{nAChR}$ was then further optimized using molecular dynamics (MD) simulations through the exploration of the accessible structural space for the complex [20] [21]. We used the eleven compounds (including compounds contained in tobacco products such as nicotine) that were co-crystalized with nAChRs or AChBPs to elucidate the ligand binding interactions because there are $\alpha 4 \beta 2$ binding data for these eleven compounds. These eleven $\alpha 4 \beta 2$-ligand complex structures were obtained from molecular docking and further optimized by MD simulations. Examining the binding modes of these compounds in the $\alpha 4 \beta 2 \mathrm{nAChR}$ homology model revealed that hydrophobic interactions between ligands and V96, L97 and F151 of the $\alpha 4$ subunit and L111, F119 and F121 of the $\beta 2$ subunit and the hydrogen bonds with S153 and W154 of the $\alpha 4$ subunit played key roles for the ligand binding.

The 3D structures of our human $\alpha 4 \beta 2$ nAChR homology model, its eleven ligand-bound complexes (supplementary materials which were made publically available), and the elucidated key interactions of these ligands in the $\alpha 4 \beta 2$ binding pocket, could be used to develop a model for rapid screening of tobacco constituents with addiction potential through human $\alpha 4 \beta 2 \mathrm{nAChR}$ binding.

\section{Material and Methods}

\subsection{Study Design and Workflow}

The study design and workflow were shown in Figure 1. Briefly, the human $\alpha 4 \beta 2 \mathrm{nAChR}$ (target) sequences were first searched in the PDB using BLAST to select a highly homologous protein (template). The 3D structure of human $\alpha 4 \beta 2 \mathrm{nAChR}$ was then built using homology modeling. After docking the ligand co-crystalized with the template protein, the initial $\alpha 4 \beta 2$-ligand complex was then optimized with MD simulations. After MD optimization, the ligand was removed from the complex. The remaining optimized 3D structure of human $\alpha 4 \beta 2$ 


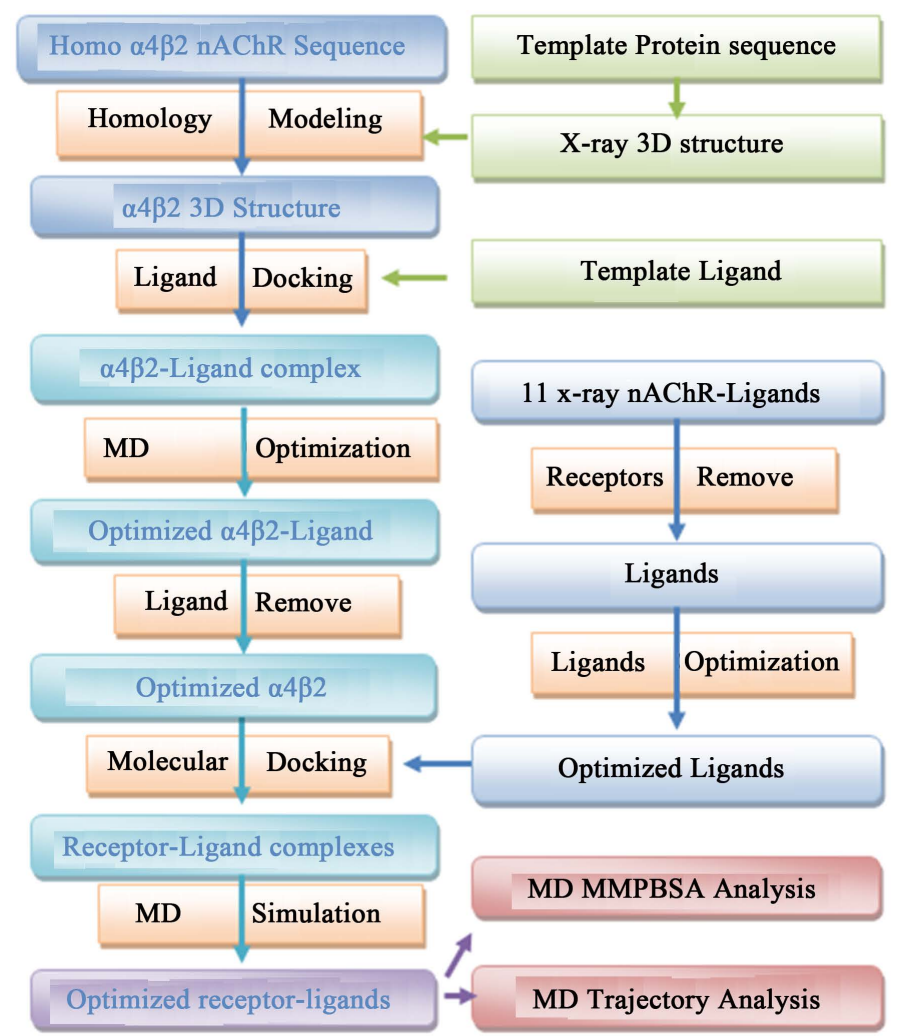

Figure 1. Study design and overall workflow. BLAST was used to search the human $\alpha 4 \beta 2$ nAChR sequence against PDB to select a template sequence for homology modeling. The initial homology model was then optimized using MD simulations. Eleven structurally diverse ligands PDB were docked into the optimized $\alpha 4 \beta 2$ and followed by MD simulations.

nAChR was used to define a binding grid for subsequent docking analyses. Eleven structurally diverse $\alpha 4 \beta 2$ ligands were selected from PDB database and their 3D structures were built and optimized. The optimized ligands were then docked into the $\alpha 4 \beta 2$ binding pocket. The $\alpha 4 \beta 2$-ligand complexes obtained from docking were further optimized through MD simulations. Finally, the protein-ligand interactions were analyzed by examining the trajectory of MD simulations.

\subsection{Homology Modeling}

The tertiary structure of a protein is better conserved than its amino acid sequence [22] [23]. Homology modeling is widely used to construct atomic-resolution models for proteins without experimentally determined structures from their amino acid sequences and experimental 3D structures of related homologous proteins [12] [24]. The homology model of human $\alpha 4 \beta 2$ nAChR was built using Maestro 9.6 in the Schrödinger Suite [25]. The extracellular ligand-binding domain sequences of the human $\alpha 4 a n d ~ \beta 2 \mathrm{nAChR}$ subunits were downloaded from UniProt database [26] ( $\alpha 4$ : P43681(29-242), ACHA4_HUMAN and $\beta 2$ : P17787(26-233), ACHB2_HUMAN). The 3D structure of Ct-AChBPs (UniprotID: I6L8L2) was downloaded from PDB (PDB ID: 4AFH) [19] as the template structure. The template sequence was identified through searching the target human $\alpha 4 \beta 2$ sequences in PDB using the BLAST homology searching with default parameters in the Prime 3.4. The target and the template sequences were aligned using the ClustralW method employed in Prime 3.4. The hetero-multimer model was used to predict the secondary structure of human $\alpha 4 \beta 2$ dimer. The ligand co-crystalized with the template protein was removed before homology modeling.

\subsection{Molecular Docking}

There are many structure-activity relationship techniques such as pharmacophore modeling [27]-[29], comparative molecular field analysis [30] [31], machine learning methods [32] such as classification tree model [33] and 
Decision Forest models [34]-[41] based on molecular descriptors [42] that are calculated using the algorithm developed for the expert systems of structure elucidation [43]-[49], and molecular docking [15] [50] [51]. Molecular docking was used in our previous studies of interactions between ligands and estrogen receptors [52] [53] for prediction of estrogenic activity [54] and endocrine disruptions [53] [55]. A similar docking protocol was adopted in this study. The 3D structure of $\alpha 4 \beta 2 \mathrm{nAChR}$ obtained from homology modeling followed by MD optimizations was prepared using the "protein preparation" tool in the Schrödinger suite [25]. The protein structures were optimized to reach the converged RMSD of 0.3 angstrom $(\AA)$ under OPLS_2005 force field. The grid box was defined using "receptor Grid Generation" tool also in the Schrödinger suite. The grid was set as a $15 \times$ $15 \times 15(\mathrm{x} \times \mathrm{y} \times \mathrm{z}, \AA)$ cubic box around the ligand thus comprising the entire binding pocket.

The two-dimensional (2D) structures of the eleven compounds co-crystalized with AChBPs in PDB are shown in Figure 2. Hereafter, the 3-letter symbols given in Figure 2 will be used to indicate the ligands for simplicity; their names and experimental activity data are also given in Supplementary Table S1. Their 3D structures of the ligands were obtained from the corresponding PDB files of the bound AChBP complexes and further optimized usingLigPrep2.8 tool and OPLS_2005 force field in Schrödinger suite. Epik 2.6 tool of Schrödinger suite was used to generate the ligands ionization states at $\mathrm{pH} 7.0 \pm 2.0$. The optimized ligands were docked into the docking grid in the 3D structure of $\alpha 4 \beta 2$ using Glide 6.1 tool in the Schrödinger suite with standard precision (SP). The binding poses with the top glide scores were selected and the corresponding complexes were output for subsequent MD simulations.

\subsection{Simulations}

The 3D structure of the human $\alpha 4 \beta 2$ homology model and the eleven $\alpha 4 \beta 2$-ligand complexes output from molecular docking were optimized using MD simulations. The MD simulations were carried out through AMBER11 [56] using the Amber ff99SB force field [57] and general Amber force field (GAFF) [58] for the receptor and ligands, respectively. AM1-BCC charges [59] were added for the ligands using Antechamber. The topology and parameters of the complexes were constructed by LEAP program [56]. Each complex was solvated with TIP3P water molecules with a $10.0 \AA$ truncated octahedron periodic box. Sodium ions were added to maintain charge neutrality of the systems. The SHAKE algorithm [60] was used to constrain the bonds involving hydrogen. The Particle-mesh Ewald (PME) algorithm [61] was used to deal with the long-range interactions with a $8.0 \AA$ non-bonded interactions cutoff. Prior to MD production simulations, a total of 10,000 steps of minimizations were applied to the entire model system including solvent molecules, followed by 2000 steps of steepest-descent, and subsequently 8000 steps of conjugated gradient minimizations. Two hundred ps (picoseconds) of equilibrations were applied to the system to reach the stable state. The molecular systems were heated in NVT ensemble from 0 to $300 \mathrm{~K}$ gradually over $200 \mathrm{ps}$ with weak harmonic potential solutes restrained. After equilibration, 50 and 10 ns (nanoseconds) NPT ensemble MD simulations were performed for the $\alpha 4 \beta 2$ homology model and its eleven ligand-bound complexes, respectively, at $1 \mathrm{~atm}$ pressure, temperature of $300 \mathrm{~K}$ and a time step of $2 \mathrm{fs}$ (fem to seconds). The coordinates of the systems were saved every $10 \mathrm{ps}$ for subsequent trajectory analyses.

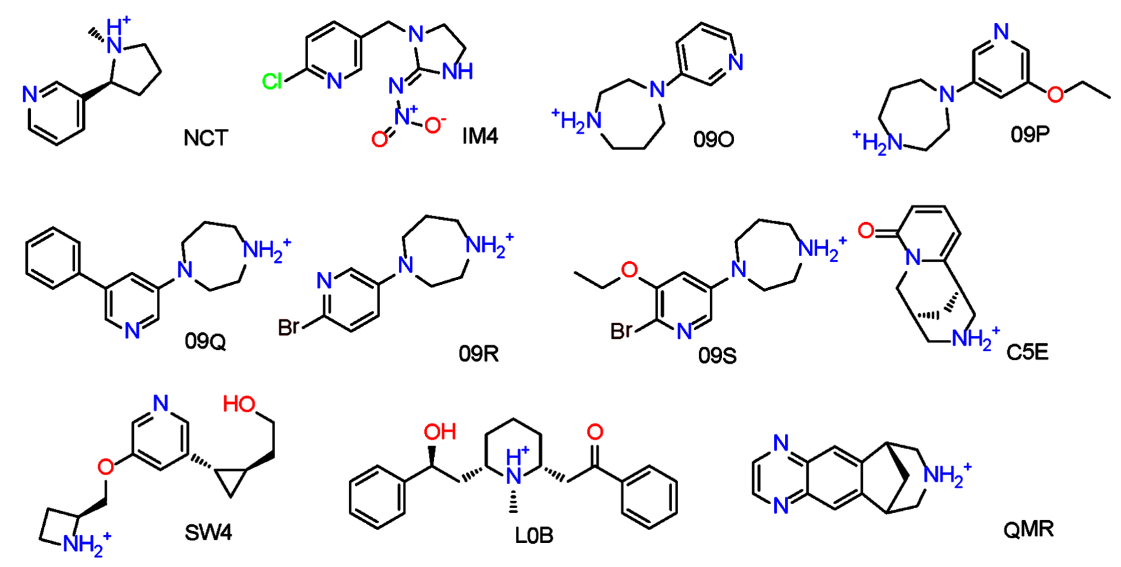

Figure 2. Chemical structures of the eleven compounds in the AChBPs complexes collected from PDB and their names used in this paper. 


\section{Results and Discussion}

\subsection{Optimized 3D Structure of Human $\alpha 4 \beta 2$ nAChR Homology Model}

The sequences of the $\alpha 4$ and $\beta 2$ subunits of the human nAChRs were queried using the BLAST algorithm to select a template structure in the protein data bank (PDB) to be used for the homology modeling of the human $\alpha 4 \beta 2 \mathrm{nAChR}$. The $\alpha 4$ subunit sequence was aligned with 811 sequences in PDB (see Supplementary Table S2). The $\beta 2$ subunit sequence was aligned with 765 sequences in PDB (see Supplementary Table S3). Recent studies have demonstrated that 3D structures can be constructed using homology modeling based on template structures of proteins with $25 \%$ or higher sequence identity to the target proteins [62] [63]. The 3D structure of marine annelid Ct-AChBP with PDB ID 4B5D at a resolution of $2.2 \AA$ has been successfully used previously as the template for the homology modeling of $\alpha 4 \beta 2 \mathrm{nAChR}$ to study the structural determinants of ligand recognition inhuman $\alpha 4 \beta 2$ nAChR [11]. The crystal structure of Ct-AChBP with a higher resolution of $1.88 \AA$ had been determined recently and deposited in PDB (ID: 4AFH). The $\alpha 4$ and $\beta 2$ subunit sequences were found to have 31\% and $28 \%$ sequence identities, respectively, with the $4 \mathrm{AFH}$ structure. Therefore, this was used as the template to construct the homology model of the human $\alpha 4 \beta 2$ nAChR.

The final alignment between the template and the target with the secondary structure prediction is shown in Figure 3 (the first three residues of $\alpha 4$ subunit were not included in the homology modeling because they could not be aligned to the template sequence).Most of the secondary structures including the disulphide bridges aligned well between the template and the target. The core residues located at the dimer interface, include residues Y98, W154 and Y195from the $\alpha 4$ subunit and residues W57, V111, F119 and L121 from the $\beta 2$ subunit. These core residues played key roles in $\alpha 4 \beta 2$-ligand interactions, which is consistent with the interactions between the human $\alpha 4 \beta 2 \mathrm{nAChR}$ and the nicotine addiction treatment drug varenicline derived from analysis using the structure-guided mutagenesis [19].

The 3D structure of the human $\alpha 4 \beta 2$ dimer shown in Figure 4(a) was constructed by homology modeling using the structure of Ct-AChBP (Figure 4(b)) as the template. The homology model superimposed well with the template structure as depicted in Figure 4(c). Consistent with our expectation, the $\alpha$ helices and $\beta$ sheets in both the template and target structures were more conserved compared to the loops. Our homology model was

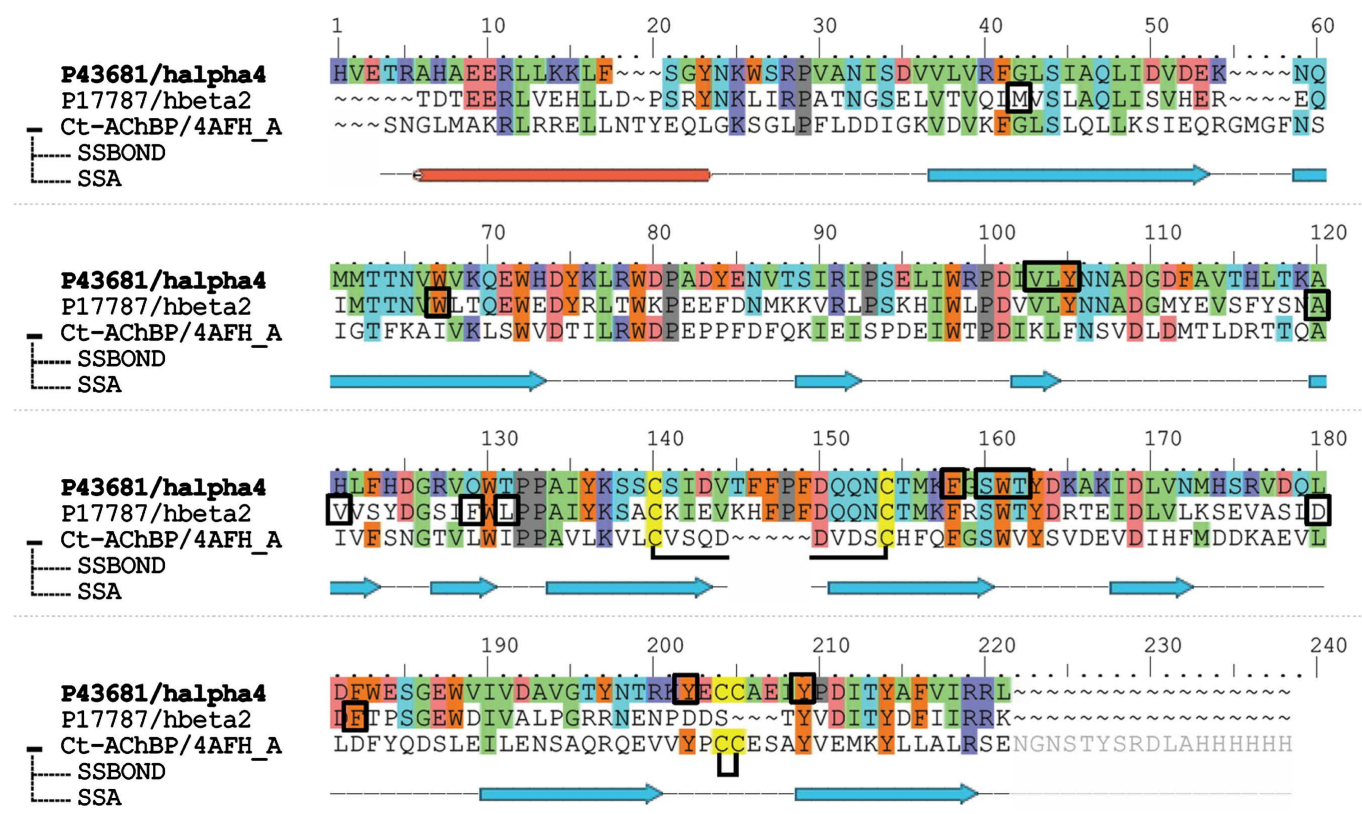

Figure 3. Sequence alignment result between the human $\alpha 4 \beta 2 \mathrm{nAChR}$ and the template Ct-AChBP. The predicted secondary structure from Ct-AChBP is also shown: the tube represents the helix; arrows indicate strands; and dotted lines depict loops. The identical residues are highlighted in colors according to the property of the corresponding query residue in the alignment to depict the location of charged (purple: positive charge; red: negative charge), aromatics (brown), polar (cyan), hydrophobic (green) and special (yellow: cysteine; grey: proline) query residues. The residues that interact with the ligands are marked with black boxes. 


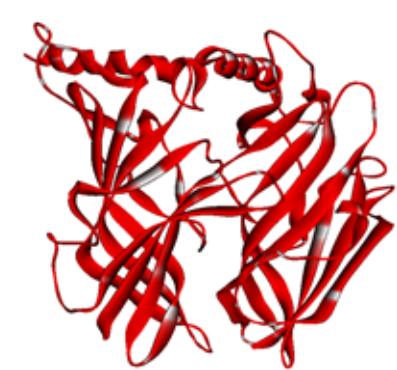

(a)

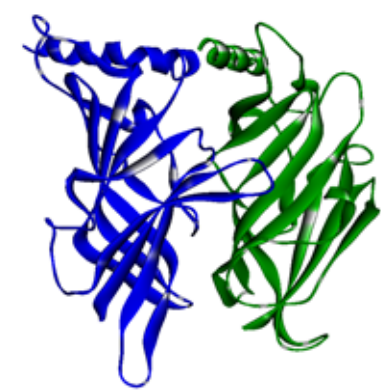

(b)

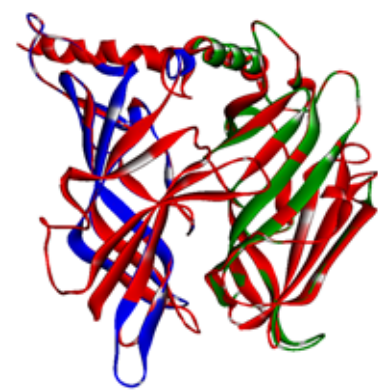

(c)

Figure 4. Homology model of the human $\alpha 4 \beta 2$ nAChR. Template structure Ct-AChBP color coded in red (a) and the homology model is shown in solid blue ribbons for $\alpha 4$ and green ribbons for $\beta 2$ (b). Superimposition of the homology model with the template is depicted in (c).

compared with the homology model constructed using a template structure of the same protein with a slightly lower resolution [11]. The overall structure and key structural features were similar.

More often than not, initial 3D structures from homology modeling were further optimized using MD simulations [64]. MD simulations are a technique widely applied to study protein folding, protein dynamics and protein-ligand interactions [20] [21] [65]-[69]. Considering the ligand impact on the residues conformations in the binding pocket [20] of the $\alpha 4 \beta 2$ homology model, MD simulations were performed in the presence of the ligand (LOB) (co-crystallized in the Ct-AChBP template protein). The root mean square deviation (RMSD) values of the optimized human $\alpha 4 \beta 2$-LOB complex structure were calculated to characterize the dynamic property of the molecular system during the MD simulations and were plotted in Figure 5(a). The molecular system reached stable states during the 50 ns simulations. The RSMD value of human $\alpha 4 \beta 2$ backbone atoms was stabilized at $3.5 \AA$ after $30 \mathrm{~ns}$ simulations and the ligand fluctuated stably from $43 \mathrm{~ns}$ with a RMSD of $2.0 \AA$. The optimized human $\alpha 4 \beta 2$ homology model is available upon request.

The root-mean-square fluctuations (RMSF) of residues of the human $\alpha 4 \beta 2$ homology model during the MD simulations were calculated to characterize the mobility of the individual residues and plotted in Figure 5(b). As expected, the $\mathrm{N}$-terminal alpha helix and the 10 beta strands are more rigid than the loops and, thus, had smaller RMSF values. The peaks in Figure 5(b) indicated larger RMSF values for the residues in the loops: 130 - 140, 170 - 180, 260 - 270, 280 - 290, 340 - 350 and $400-410$.

The Ramachandran plot (Figure 5(c)) showed that $99.3 \%$ of the residues in the optimized $\alpha 4 \beta 2$ structure were in the favorable regions-higher than the percentage of residues (96.2\%, see Figure 5(d)) in the initial homology model without MD simulations - thus indicating that the homology model of human $\alpha 4 \beta 2$ was optimized to an energy stable state.

To examine the structural changes of the $\alpha 4 \beta 2$ homology model following the MD simulations, the structures before and after the optimization were superimposed together and depicted in Figure 5(e). The two structures superimposed well with each other, especially for the $\beta$-sandwich cores, providing evidence that the homology model is a reasonably stable structure. On the other hand, much larger changes in the loop regions (some near the ligand binding site) were observed during the simulations points towards a better characterized ligand binding pocket for the $\alpha 4 \beta 2$. This indicates that optimization using MD simulations is a necessary step for the structural refinement of the human $\alpha 4 \beta 2$ homology model.

To examine the binding interactions between the human $\alpha 4 \beta 2$ homology model and the cognate ligand in the template, LOB, the zoomed-in view of the receptor ligand binding pocket is shown in Figure 5(f). The tertiary amine of LOB was stabilized through the $\pi$-cation interactions with the conserved aromatic residues W154 and Y195. The benzene ring of LOB also interacted with the piperidine ring of residue W154through $\pi-\pi$ interactions. The receptor-ligand hydrophobic interactions mainly involved residues V96 and L97 from the $\alpha 4$ subunit and V111, F119 and L121 from the $\beta 2$ subunit. The binding interactions observed for the human $\alpha 4 \beta 2$ homology model were similar to those between LOB and Ct-AChBP elucidated from the X-ray structure [19].

\subsection{Ligands Docking}

Site Map [70] was used to generate the potential ligand binding site of the extracellular domains of human 


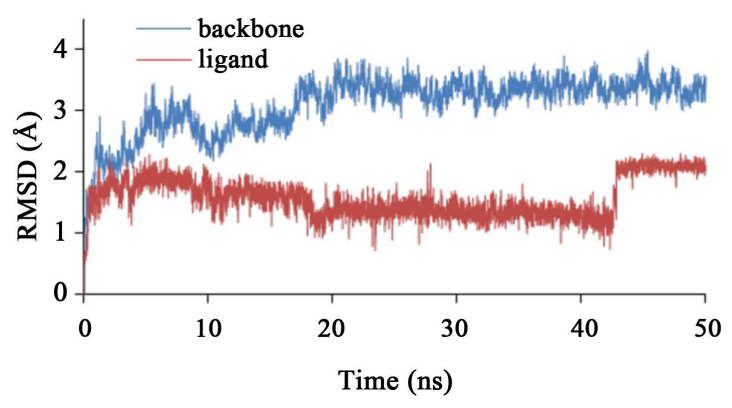

(a)

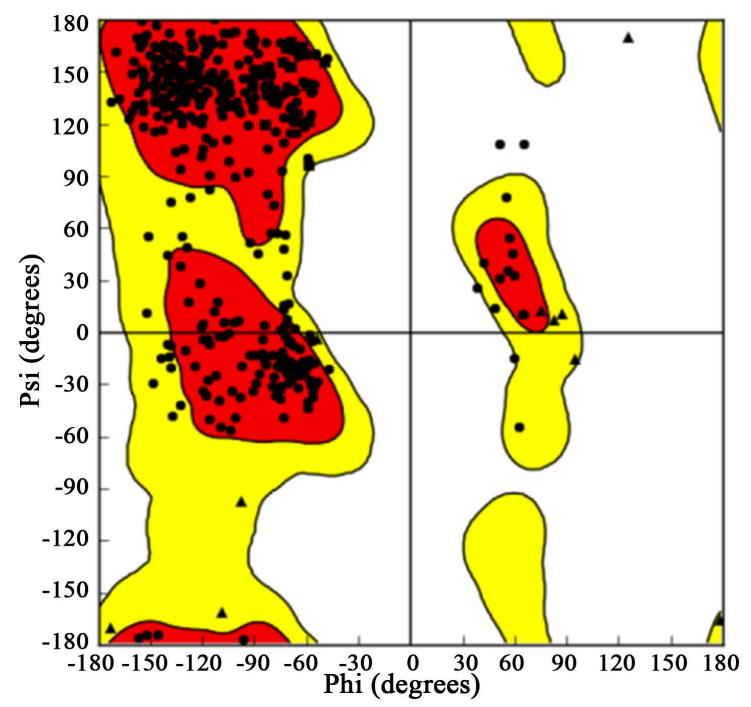

(c)

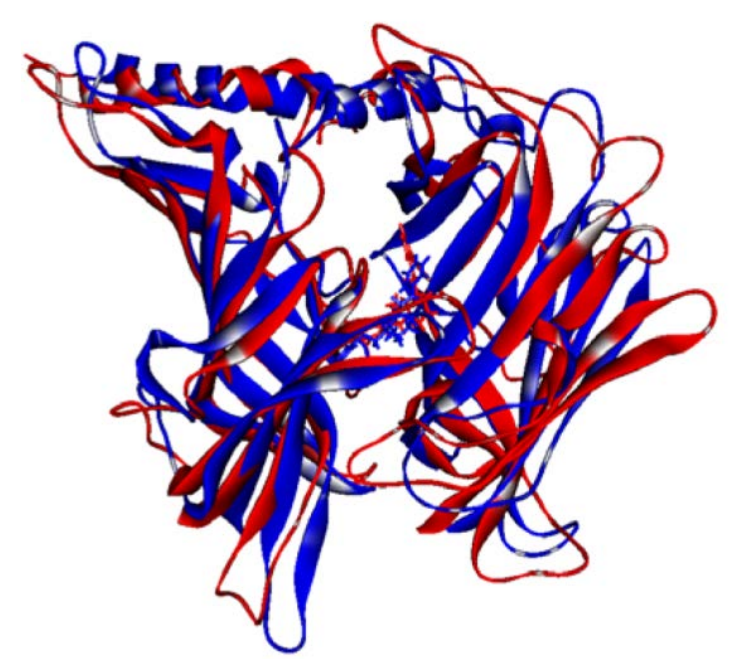

(e)

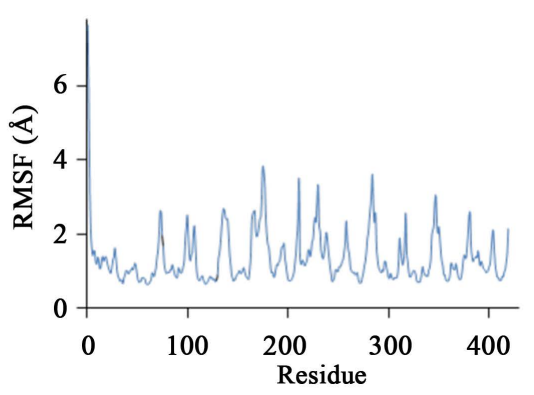

(b)

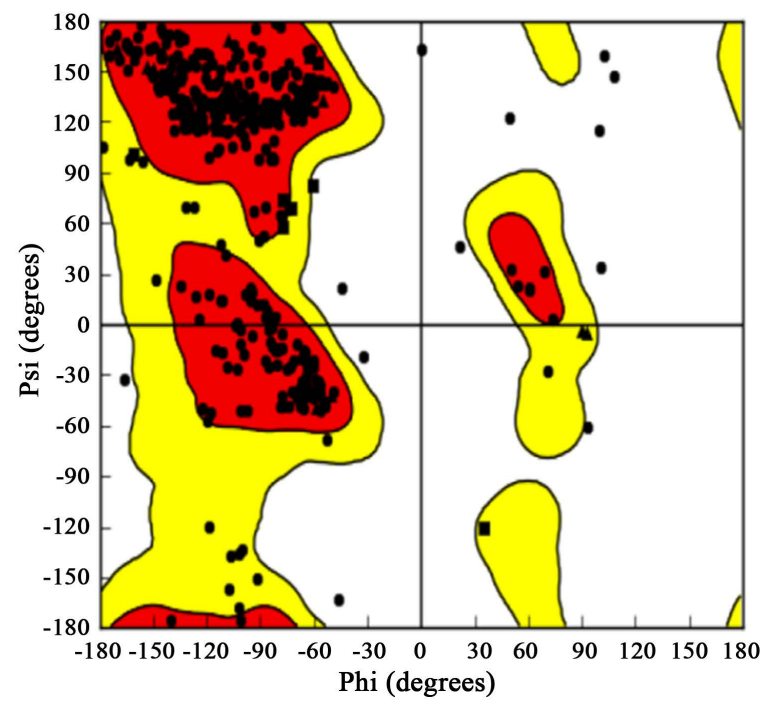

(d)

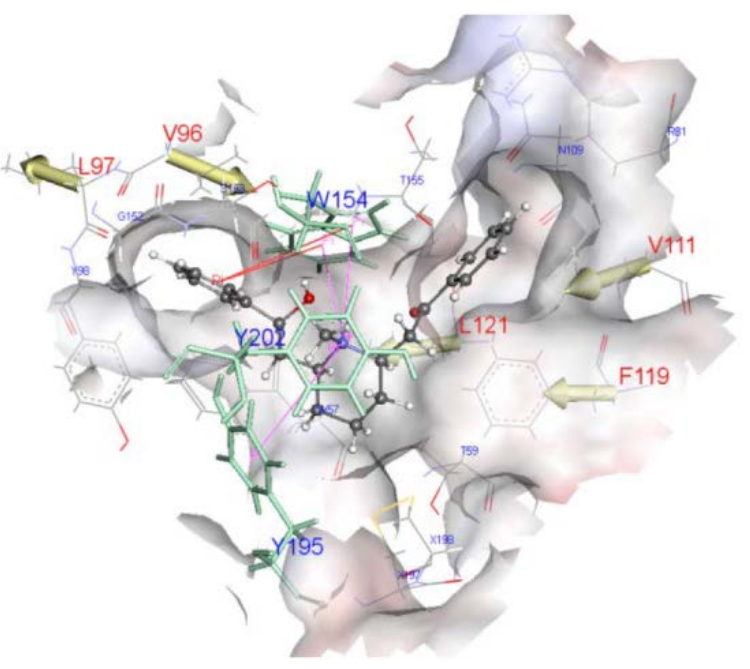

(f)

Figure 5. Optimization of the homology model by MD simulations. The RMSD values (y-axis) for atoms of protein backbone (blue line) and ligand (red line) during the optimization (x-axis) were plotted in (a). The RMSF values (y-axis) of individual residues (x-axis) were given in (b). Ramachandran plots of the optimized and initial homology models were given in (c) and (d), respectively. The homology models before (blue ribbon) and after (red ribbon) the MD simulations were superimposed (e). The binding pocket was illustrated by a zoomed surface representation (f). The core residues were color coded in blue. The arrows indicated the hydrophobic moment (residues colored in red). The red lines depicted the $\pi$ - $\pi$ interaction and the purple lines for the $\pi$-cation interaction. 
$\alpha 4 \beta 2 \mathrm{n}$ AChR homology model. The eleven ligands shown in Figure 2 were docked in the receptor model. For each ligand, the lowest docking score and its corresponding docking pose in the receptor were selected and output for subsequent analysis. The docking poses of all eleven ligands in the human $\alpha 4 \beta 2 \mathrm{nAChR}$ homology model are shown in Figure 6 and Supplementary Figure S1. The ligand binding site composed of the $\alpha 4$ subunit residues V96, L97, Y98, S153, W154, Y195 and Y202 and the $\beta 2$ subunit residues W57, V111, F119, L121 and F157. The orientations of the eleven ligands were similar i.e. the hydrophobic parts of all the ligands extended into the major surface of the binding pocket. Aromatic and hydrophobic interactions were the major contributions to the binding.

\subsection{Ligand Binding Interactions}

To elucidate the binding modes of the eleven ligands in the human $\alpha 4 \beta 2$ receptor, the complexes of $\alpha 4 \beta 2$ bound with the ligands resulting from the molecular docking were again optimized using MD simulations [71] [72]. MD simulations were carried out on the eleven human $\alpha 4 \beta 2$-ligand complexes obtained from molecular docking and the results were given in Figure 7. The RMSD values generated by the MD simulations for the proteins (Figure 7(a)) and the ligands (Figure 7(b)) indicated the complexes reached relatively stable states. In more detail, for the structures of $\alpha 4 \beta 2$ homology model bound with IM4, 09O, 09R, LOB and QMR ligands, the irreceptor RMSD values stabilized around $2.0 \AA$ after 6 ns MD simulations. On the other hand, the structures of $\alpha 4 \beta 2$ homology model bound with NCT, 09P, 09Q, 09S, SW4 and C5E continued to show small fluctuations of the receptor (RMSD values of $\sim 2.5 \AA$ ) after 6 ns MD simulations. Furthermore, as expected, the rigid ligands (C5E and QMR) remained highly stable as evidenced by a low RMSD of $0.3 \AA$ during the whole simulations; the ligands with one rotatable bond (NCT and 09R) had slightly larger fluctuations of $\sim 1 \AA$ RMSD; the ligands with multiple rotatable bonds (e.g. 09Q, 09S, and SW4) had larger fluctuations in the simulations. In other words, the more rotatable bonds in a ligand, the larger the RMSD. Interestingly, LOB has six rotatable bonds but its conformation only changed slightly with RMSD values of about $0.5 \AA$ during the simulations. This indicates that the fluctuation of a ligand in simulations depends not only on the ligand structure but also on its binding environment [73] [74].

To elucidate the binding interactions of the eleven ligands, the corresponding receptor-ligand complexes from the final frame of the MD simulations were examined. The binding mode of NCT was shown in Figure 8(a). On the $\alpha 4$ subunit side, NCT had extensive binding with residues Y98, S153, W154 and Y202 through hydrogen bond, $\pi-\pi$ and $\pi$-cation interactions. It also bound with the hydrophobic residues V96, L97 and F151 through hydrophobic interactions. On the $\beta 2$ subunit side, the ligand bound with W57 and L121 through $\pi$-sigma interactions and hydrophobic interactions. The receptor-ligand interactions observed for the human $\alpha 4 \beta 2 \mathrm{nAChR}$ are consistent with the ones found in AChBP crystal complex of the same ligand [72].

The binding interactions between $\alpha 4 \beta 2$ and IM4 were shown in Figure 8(b). The pyridine ring of IM4 interacted with $\alpha 4 \beta 2$ through the $\pi$ - $\pi$ interactions with residue Y195 of the $\alpha 4$ subunit and the hydrophobic interact-

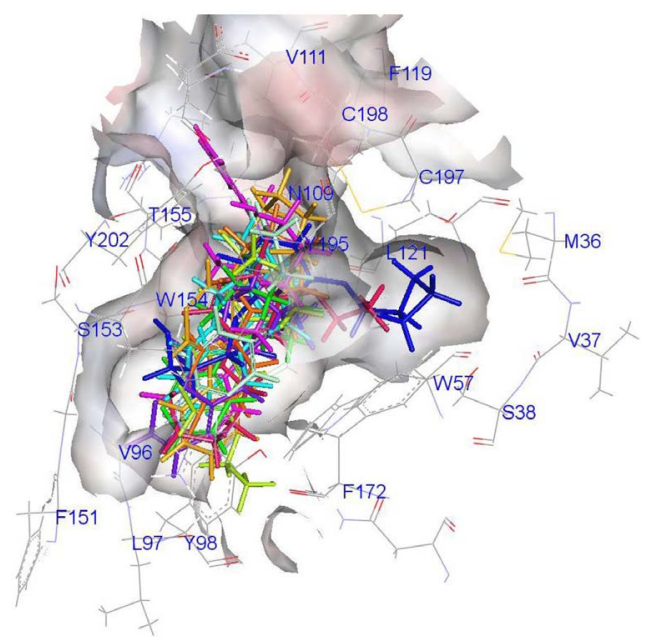

Figure 6. Docking poses of the eleven ligands in the binding site of human $\alpha 4 \beta 2$. 

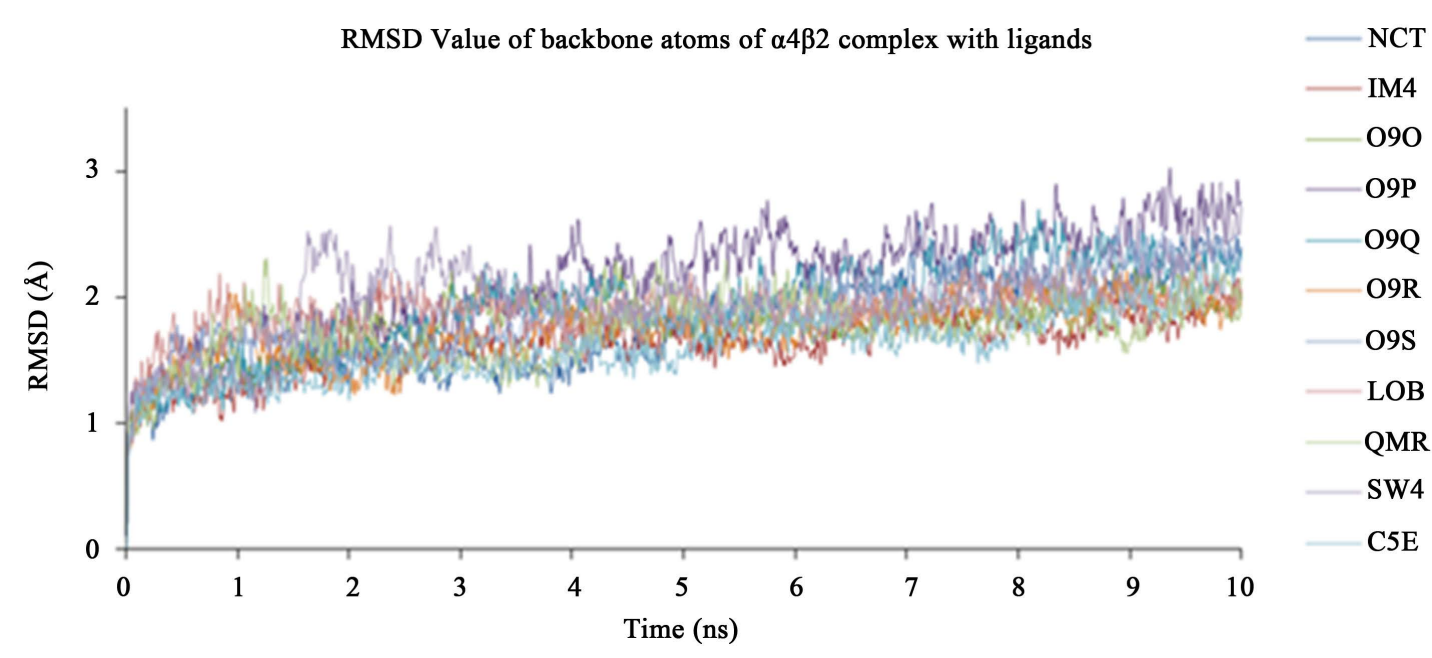

(a)

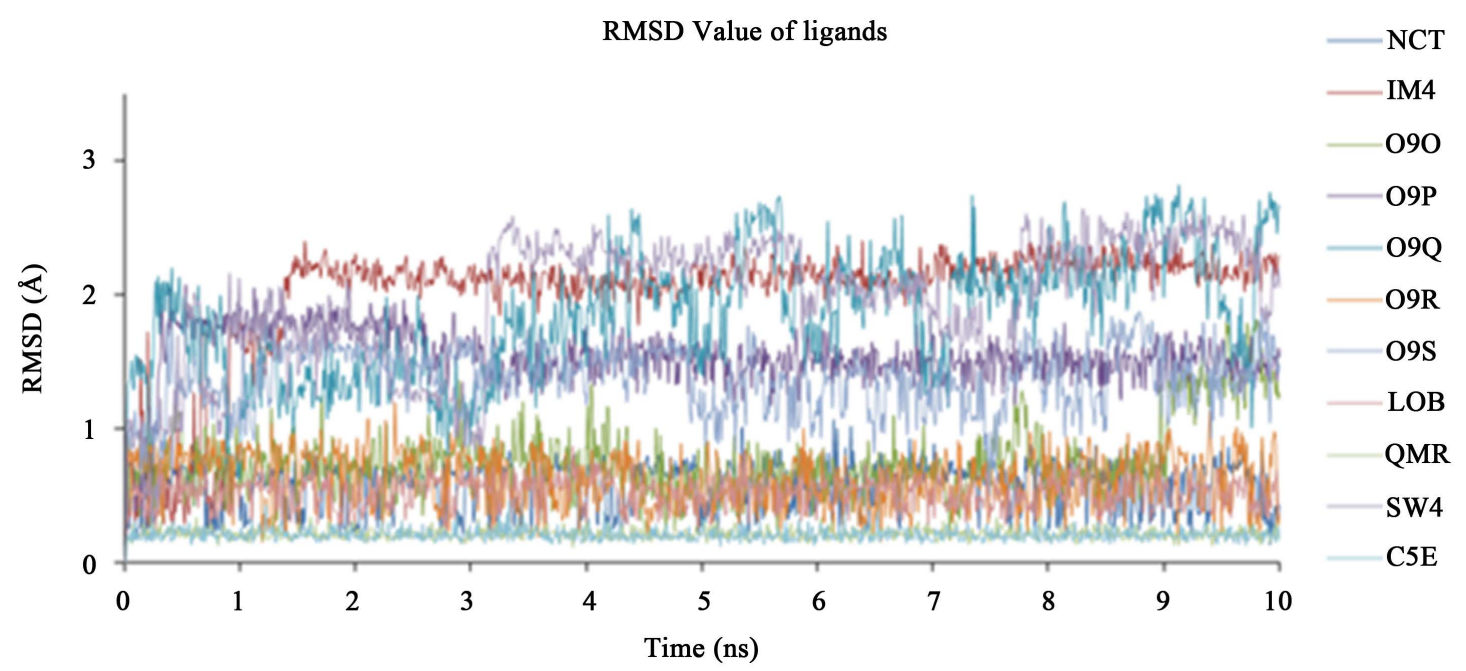

(b)

Figure 7. Trajectory analyses of MD simulations. The RMSD values of the protein backbones (a) and the ligands (b) were plotted again the time. The complexes are indicated by the ligand abbreviations using different colors shown in the legends.

tions with residues L111, L119 and F172 of the $\beta 2$ subunit. The binding mode of IM4 in the human $\alpha 4 \beta 2$ elucidated in this study was similar to the one observed in the crystal structure of the Ls-AChBP complex bound with IM4 [74].

Ligands 09O, 09P, 09Q, 09R and 09S share a structural fragment in which a diazepane and a pyridine are connected by a single bond. Their binding interactions with the human $\alpha 4 \beta 2$ homology model are depicted in Figures 8(c)-(g), respectively. Although the binding modes of these ligands in the receptor were not the same due to the structural elements attached to the common fragment, the binding interactions formed were similar. These interactions were hydrogen bond, hydrophobic, $\pi$ - $\pi$ and $\pi$-cation interactions. The $\pi$ - $\pi$ and $\pi$-cation interactions mainly occurred between the diazepane and pyridine of the ligands and the residues W154, Y195, Y202, V96, L97 and Y98 of the $\alpha 4$ subunit and the residues W57, L121, F172 and F119 of the $\beta 2$ subunit. These binding interactions as elucidated from our MD simulations are consistent with the ones identified in the AChBP $\mathrm{X}$-ray complex structures bound with the respective ligands [75].

The ligand binding mode ofSW4is illustrated in Figure 8(h). SW4 forms a hydrogen bond with residue Y196 of the $\alpha 4$ subunit and had $\pi$-cation and hydrophobic interactions with residues V111, F119 and F121 of the $\beta 2$ subunit. These binding interactions were observed in the x-ray crystal structure of the Ct-AChBP bound with SW4 [11]. 


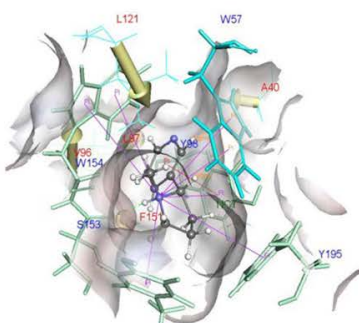

(a)

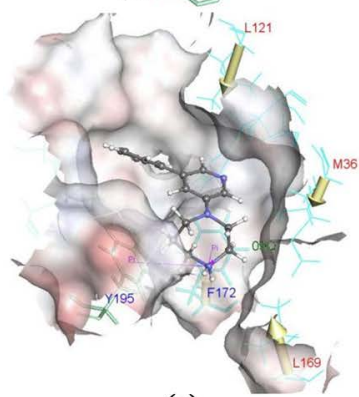

(e)

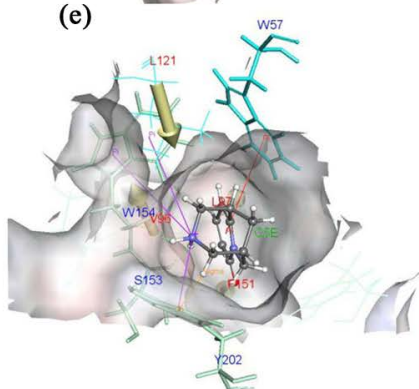

(i)

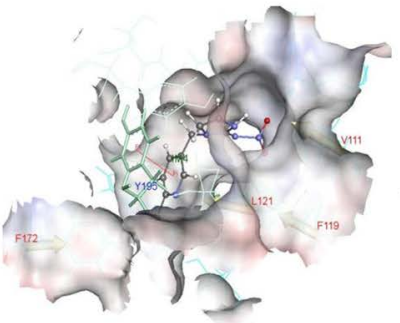

(b)

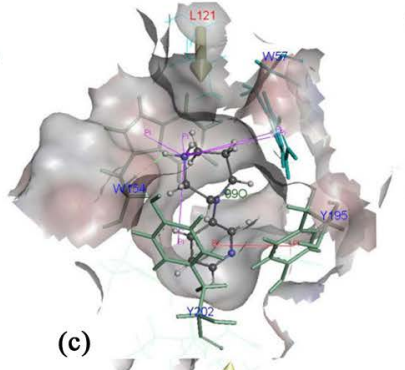

(c)

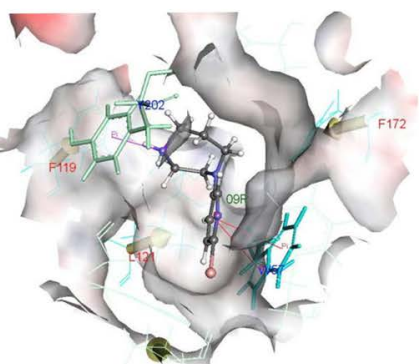

(f)

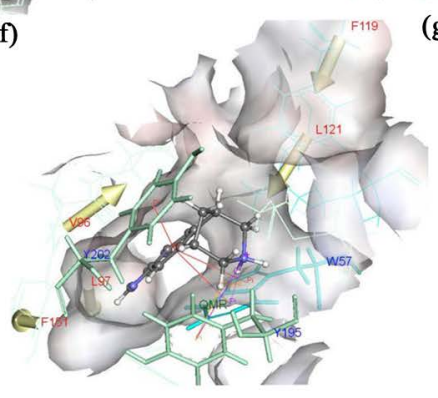

(j)

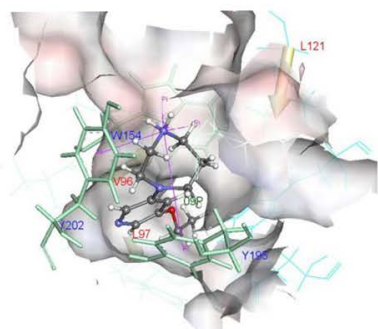

(d)

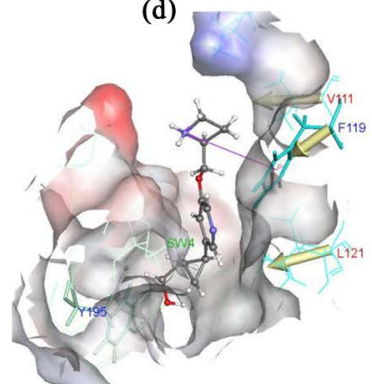

(h) (g)

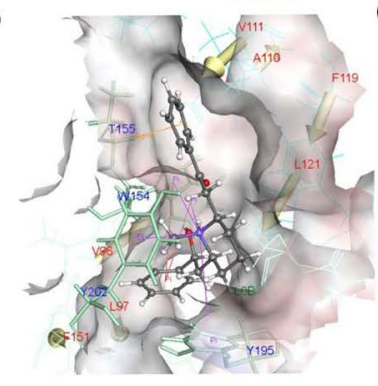

(k)

Figure 8. Ligands binding modes. Binding pocket surfaces are colored in the interpolated charge. The core residues are in cyan and the arrows indicated the hydrophobic moments (residues were labelled in red).The red lines depicted the $\pi-\pi$ interaction and the purple lines for the $\pi$-cation interaction. The ligands in the complexes: NCT (a); IM4 (b); 090 (c); 09P (d); 09Q (e); 09R (f); 09S (g); LOB (h); QMR (i); SW4 (j) and C5E (k).

Figure 8(i) depicts the binding mode ofC5E.The ligand bound with the human $\alpha 4 \beta 2$ through hydrogen bonds, $\pi$-cation interactions, $\pi$-sigma interactions and hydrophobic interactions with the residues V96, L97, F151, S153, W154 and Y202 of the $\alpha 4$ subunit. It also has $\pi-\pi$ interactions and hydrophobic interactions with the residues W57 and L121 of the $\beta 2$ subunit. The binding interaction was confirmed in the x-ray structure of Ac-AChBP complex bound with C5E [76].

The binding mode of QMR is shown in Figure 8(j). This highly rigid ligand bound to the binding pocket through $\pi-\pi$ interactions, $\pi$-cation interactions, $\pi$-sigma interactions and hydrophobic interactions with residues V96, L97, F151, Y195 and Y202 of the $\alpha 4$ subunit and the side chains of residues W57, F119 and F121 of the $\beta 2$ subunit. These binding interactions were in a good agreement with the Ac-AChBP complex bound with the same ligand [76].

The binding mode of LOB is given in Figure 8(k). LOB interacted with $\alpha 4 \beta 2$ through $\pi$-cation interactions with residues W154, Y195 and Y202 and $\pi-\pi$ interactions with W154 of the $\alpha 4$ subunit. It also had hydrophobic interactions with residues V96, L97 and F151 of the $\alpha 4$ subunit and residues V111, F119 and L121of the $\beta 2$ subunit. These molecular interactions were similar to those observed in x-ray structure of LOB-CtAChBP complex [19].

The binding interactions between the human $\alpha 4 \beta 2$ homology model and the eleven ligands were summarized in the Table 1. In general, the hydrophobic interactions mainly involved residues V96, L97 and F151 of the $\alpha 4$ subunit and residues L111, F119 and F121 of the $\beta 2$ subunit. The $\pi$ - $\pi$, $\pi$-cation, and $\pi$-sigma interactions were mainly from residues Y98, W154, Y195 and Y202 of the $\alpha 4$ subunit and from residue W57 of the $\beta 2$ subunit. 
Table 1. Summary of predicted binding interactions.

\begin{tabular}{|c|c|c|c|c|c|c|}
\hline Ligand & Name & H Bond & pi-pi & Pi-Cation & Pi-Sigma & Hydrophobic \\
\hline NCT & L-(-)-nicotine & NCT:H15-S153:O & Y98-NCT & $\begin{array}{l}\text { Y98, W154, } \\
\text { Y202-NCT:N2 }\end{array}$ & $\begin{array}{l}\text { W57-NCT:H1, } \\
\text { H5 }\end{array}$ & $\begin{array}{l}\text { V96, L97, } \\
\text { F151, L121 }\end{array}$ \\
\hline IM4 & Imidacloprid & & Y195-IM4 & & & V111, F119, F172 \\
\hline 090 & 1-(pyridin-3-yl)-1,4-diazepane & 09O:H5-W154:O & Y195-090 & $\begin{array}{l}\text { W154-09O:N1 } \\
\text { W57-09O:N1 }\end{array}$ & & L121 \\
\hline 09P & 1-(5-ethoxypyridin-3-yl)-1,4-diazepane & 09P:H3-W154:O & & $\begin{array}{l}\text { W154, Y195, } \\
\text { Y202-09P:N1 }\end{array}$ & & V96, L97, L121 \\
\hline 09Q & 1-(5-phenylpyridin-3-yl)-1,4-diazepane & & & $\begin{array}{l}\text { Y195-09Q:N2 } \\
\text { F172-09Q:N2 }\end{array}$ & & $\begin{array}{l}\text { M36, L121, } \\
\text { L169, F172 }\end{array}$ \\
\hline 09R & 1-(6-bromopyridin-3-yl)-1,4-diazepane & & W57-09R & Y202-09R:N3 & & $\begin{array}{l}\text { V96, F119, } \\
\text { L121, F172 }\end{array}$ \\
\hline 09S & $\begin{array}{l}\text { 1-(6-bromo-5-ethoxypyridin-3-yl) } \\
\text {-1,4-diazepane }\end{array}$ & Y195:HH-09S:N3 & Y195-09S & $\begin{array}{c}\text { Y98, } \\
\text { W154-09S:N1 }\end{array}$ & & $\begin{array}{l}\text { V96, L97, } \\
\text { F119, L121, F172 }\end{array}$ \\
\hline LOB & Alpha-lobeline & & W154-LOB & $\begin{array}{l}\text { W154, Y195, } \\
\text { Y202-LOB:N1 }\end{array}$ & LOB-T155:HA & $\begin{array}{l}\text { V96, L97, F151, } \\
\text { A110, V11, } \\
\text { F119, L121 }\end{array}$ \\
\hline QMR & Varenicline & & $\begin{array}{l}\text { Y202-QMR } \\
\text { W57-QMR }\end{array}$ & $\begin{array}{l}\text { Y195-QMR:N1 } \\
\text { W57-QMR:N1 }\end{array}$ & Y195-QMR:H1 & $\begin{array}{l}\text { V96, L97, F15, } \\
\text { F119, L121 }\end{array}$ \\
\hline SW4 & $\begin{array}{l}\text { 2-[(1R,2S)-2-[5-[[(2S)-azetidin-2-yl] } \\
\text { methoxy]pyridin- 3-yl]cyclopropyl]ethanol }\end{array}$ & Y195:HH-SW4:O1 & & F119-SW4:N2 & & V111, F119, F121 \\
\hline C5E & Cytisine & $\begin{array}{l}\text { C5E:H6-S153:O; } \\
\text { C5E:H15-W154:O }\end{array}$ & W57-C5E & $\begin{array}{l}\text { W154, } \\
\text { Y202-C5E:N2 }\end{array}$ & Y202-C5E:H4 & $\begin{array}{l}\text { V96, L97, } \\
\text { F151, L121 }\end{array}$ \\
\hline
\end{tabular}

The hydrogen bonds were formed between the ligands and residues S153 and W154 of the $\alpha 4$ subunit. It is worth noting that residues W154 and W57 interacted with most of the eleven ligands and played key roles in the binding as confirmed in the X-ray structures of the AChBPs bound with the respective ligands [19] [77]. It is worth noting that in this study, we focus on the binding of these ligands to the human $\alpha 4 \beta 2$ nAChR i.e. the pre-requisite step for chemicals to elicit subsequent pharmacological actions on the body-indeed, the ligands considered in this study display different pharmacology (various degree of activation and desensitization) upon binding to the human $\alpha 4 \beta 2 \mathrm{nAChR}$. However, this aspect is out of the scope of our study.

\section{Conclusion}

The human $\alpha 4 \beta 2 \mathrm{nAChR}$ plays an important role in nicotine addiction and could be used for screening tobacco constituents with addiction potential. Determining the 3D structure of the human $\alpha 4 \beta 2 \mathrm{nAChR}$ and elucidating its ligand binding interactions would help with screening for tobacco constituents with nicotine receptor binding activity and addictive properties. This type of screening will result in a rank order of tobacco constituents that have addiction potential and may inform regulation of tobacco products. As there are no 3D structures of human $\alpha 4 \beta 2$ nAChR either alone or bound with ligands available to researchers today, we constructed a homology model of the human $\alpha 4 \beta 2 \mathrm{nAChR}$ based on the X-ray structure of the Ct-AChBP complex bound with LOB as an alternative approach for gaining insights into ligand binding characteristics of the human $\alpha 4 \beta 2 \mathrm{nAChR}$. Based on the homology model of the human $\alpha 4 \beta 2 \mathrm{nAChR}$, we further characterized the ligand binding interactions of human $\alpha 4 \beta 2 \mathrm{nAChR}$ by docking eleven ligands to the receptor followed by MD simulations. Our results provide molecular details into the ligand binding interactions with human $\alpha 4 \beta 2 \mathrm{nAChR}$ homology model and a modeling method for identifying nicotine receptor binding compounds that are potentially addictive.

\section{Acknowledgements}

This project was funded by the Center for Tobacco Products at the U.S. Food and Drug Administration. This research was supported in part by an appointment to the Research Participation Program at the National Center for Toxicological Research (Hui Wen Ng and Hao Ye) administered by the Oak Ridge Institute for Science and Education through an interagency agreement between the U.S. Department of Energy and the U.S. Food and 
Drug Administration. This publication represents the views of the author(s) and does not represent CTP position or policy.

\section{Author Contributions}

H.H. and M.O. conceived and designed the experiments; M.S. and H.W.N. performed the experiments; M.S., H.W.N., H.L., H.Y. and W.G. analyzed the data; M.S., M.S., W.T. and H.H. wrote the paper.

\section{Conflicts of Interest}

The authors declare no conflict of interest.

\section{References}

[1] Dube, S., Asman, K., Malarcher, A. and Carabollo, R. (2009) Cigarette Smoking among Adults and Trends in Smoking Cessation-United States, 2008. Morbidity and Mortality Weekly Report, 58, 1227-1232.

[2] Benowitz, N.L. (2009) Pharmacology of Nicotine: Addiction, Smoking-Induced Disease, and Therapeutics. Annual Review of Pharmacology and Toxicology, 49, 57-71. http://dx.doi.org/10.1146/annurev.pharmtox.48.113006.094742

[3] Benowitz, N.L. (2010) Nicotine Addiction. New England Journal of Medicine, 362, 2295-2303. http://dx.doi.org/10.1056/NEJMra0809890

[4] Jensen, A.A., Frølund, B., Liljefors, T. and Krogsgaard-Larsen, P. (2005) Neuronal Nicotinic Acetylcholine Receptors: Structural Revelations, Target Identifications, and Therapeutic Inspirations. Journal of Medicinal Chemistry, 48, 47054745. http://dx.doi.org/10.1021/jm040219e

[5] Dani, J.A. and Bertrand, D. (2007) Nicotinic Acetylcholine Receptors and Nicotinic Cholinergic Mechanisms of the Central Nervous System. Annual Review of Pharmacology and Toxicology, 47, 699-729. http://dx.doi.org/10.1146/annurev.pharmtox.47.120505.105214

[6] Liu, X. (2014) Effects of Blockade of Alpha 4 Beta 2 and Alpha 7 Nicotinic Acetylcholine Receptors on Cue-Induced Reinstatement of Nicotine-Seeking Behaviour in Rats. International Journal of Neuropsychopharmacology, 17, 105116. http://dx.doi.org/10.1017/S1461145713000874

[7] Albuquerque, E.X., Pereira, E.F., Alkondon, M. and Rogers, S.W. (2009) Mammalian Nicotinic Acetylcholine Receptors: From Structure to Function. Physiological Reviews, 89, 73-120. http://dx.doi.org/10.1152/physrev.00015.2008

[8] Millar, N.S. and Gotti, C. (2009) Diversity of Vertebrate Nicotinic Acetylcholine Receptors. Neuropharmacology, 56, 237-246. http://dx.doi.org/10.1016/j.neuropharm.2008.07.041

[9] Miwa, J.M., Lester, H.A. and Walz, A. (2012) Optimizing Cholinergic Tone through Lynx Modulators of Nicotinic Receptors: Implications for Plasticity and Nicotine Addiction. Physiology, 27, 187-199. http://dx.doi.org/10.1152/physiol.00002.2012

[10] Tapper, A.R., McKinney, S.L., Nashmi, R., Schwarz, J., Deshpande, P., Labarca, C., Whiteaker, P., Marks, M.J., Collins, A.C. and Lester, H.A. (2004) Nicotine Activation of Alpha4* Receptors: Sufficient for Reward, Tolerance, and Sensitization. Science, 306, 1029-1032. http://dx.doi.org/10.1126/science.1099420

[11] Zhang, H.K., Eaton, J.B., Yu, L.F., Nys, M., Mazzolari, A., van Elk, R., Smit, A. B., Alexandrov, V., Hanania, T., Sabath, E., Fedolak, A., Brunner, D., Lukas, R.J., Vistoli, G., Ulens, C. and Kozikowski, A.P. (2012) Insights into the Structural Determinants Required for High-Affinity Binding of Chiral Cyclopropane-Containing Ligands to Alpha 4 Beta 2-Nicotinic Acetylcholine Receptors: An Integrated Approach to Behaviorally Active Nicotinic Ligands. Journal of Medicinal Chemistry, 55, 8028-8037. http://dx.doi.org/10.1021/jm3008739

[12] Vernall, A.J., Stoddart, L.A., Briddon, S.J., Ng, H.W., Laughton, C.A., Doughty, S.W., Hill, S.J. and Kellam, B. (2013) Conversion of a Non-Selective Adenosine Receptor Antagonist into a 3-Selective High Affinity Fluorescent Probes Using Peptide-Based Linkers. Organic \& Biomolecular Chemistry, 11, 5673-5682. http://dx.doi.org/10.1039/c3ob41221k

[13] Smit, A.B., Syed, N.I., Schaap, D., van Minnen, J., Klumperman, J., Kits, K.S., Lodder, H., van der Schors, R.C., van Elk, R., Sorgedrager, B., Brejc, K., Sixma, T.K. and Geraerts, W.P. (2001) A Glia-Derived Acetylcholine-Binding Protein That Modulates Synaptic Transmission. Nature, 411, 261-268. http://dx.doi.org/10.1038/35077000

[14] Hansen, S.B., Talley, T.T., Radić, Z. and Taylor, P. (2004) Structural and Ligand Recognition Characteristics of an Acetylcholine-Binding Protein from Aplysia californica. Journal of Biological Chemistry, 279, 24197-24202. http://dx.doi.org/10.1074/jbc.M402452200

[15] McCormack, T., Petrovich, R.M., Mercier, K.A., DeRose, E.F., Cuneo, M.J., Williams, J., Johnson, K.L., Lamb, P.W., London, R.E. and Yakel, J.L. (2010) Identification and Functional Characterization of a Novel Acetylcholine-Binding 
Protein from the Marine Annelid Capitella teleta. Biochemistry, 49, 2279-2287. http://dx.doi.org/10.1021/bi902023y

[16] Rucktooa, P., Smit, A.B. and Sixma, T.K. (2009) Insight in Nachr Subtype Selectivity from Achbp Crystal Structures. Biochemical Pharmacology, 78, 777-787. http://dx.doi.org/10.1016/j.bcp.2009.06.098

[17] Haddadian, E.J., Cheng, M.H., Coalson, R.D., Xu, Y. and Tang, P. (2008) In Silico Models for the Human Alpha4beta2 Nicotinic Acetylcholine Receptor. Journal of Physical Chemistry B, 112, 13981-13990. http://dx.doi.org/10.1021/jp804868s

[18] Bisson, W.H., Westera, G., Schubiger, P.A. and Scapozza, L. (2008) Homology Modeling and Dynamics of the Extracellular Domain of Rat and Human Neuronal Nicotinic Acetylcholine Receptor Subtypes Alpha4beta2 and Alpha7. Journal of Molecular Modeling, 14, 891-899. http://dx.doi.org/10.1007/s00894-008-0340-X

[19] Billen, B., Spurny, R., Brams, M., Van Elk, R., Valera-Kummer, S., Yakel, J.L., Voets, T., Bertrand, D., Smit, A.B. and Ulens, C. (2012) Molecular Actions of Smoking Cessation Drugs at $A 4 \beta 2$ Nicotinic Receptors Defined in Crystal Structures of a Homologous Binding Protein. Proceedings of the National Academy of Sciences, 109, 9173-9178. http://dx.doi.org/10.1073/pnas.1116397109

[20] Ng, H.W., Laughton, C.A. and Doughty, S.W. (2013) Molecular Dynamics Simulations of the Adenosine A2a Receptor: Structural Stability, Sampling, and Convergence. Journal of Chemical Information and Modeling, 53, 1168-1178. http://dx.doi.org/10.1021/ci300610w

[21] Ng, H.W., Laughton, C.A. and Doughty, S.W. (2014) Molecular Dynamics Simulations of the Adenosine A2a Receptor in Popc and Pope Lipid Bilayers: Effects of Membrane on Protein Behavior. Journal of Chemical Information and Modeling, 54, 573-581. http://dx.doi.org/10.1021/ci400463z

[22] Marti-Renom, M.A., Stuart, A.C., Fiser, A., Sanchez, R., Melo, F. and Sali, A. (2000) Comparative Protein Structure Modeling of Genes and Genomes. Annual Review of Biophysics and Biomolecular Structure, 29, 291-325. http://dx.doi.org/10.1146/annurev.biophys.29.1.291

[23] Hong, H., Hong, Q., Perkins, R., Shi, L., Fang, H., Su, Z., Dragan, Y., Fuscoe, J.C. and Tong, W. (2009) The Accurate Prediction of Protein Family from Amino Acid Sequence by Measuring Features of Sequence Fragments. Journal of Computational Biology, 16, 1671-1688. http://dx.doi.org/10.1089/cmb.2008.0115

[24] Shen, J., Zhang, W., Fang, H., Perkins, R., Tong, W. and Hong, H. (2013) Homology Modeling, Molecular Docking, and Molecular Dynamics Simulations Elucidated Alpha-Fetoprotein Binding Modes. BMC Bioinformatics, 14, S6. http://dx.doi.org/10.1186/1471-2105-14-S14-S6

[25] Maestro, S. (2011) Version 9.2. LLC, New York.

[26] Uniprot Consortium (2013) Update on Activities at the Universal Protein Resource (Uniprot) in 2013. Nucleic Acids Research, 41, D43-D47. http://dx.doi.org/10.1093/nar/gks1068

[27] Hong, H., Neamati, N., Wang, S., Nicklaus, M.C., Mazumder, A., Zhao, H., Burke, T.R., Pommier, Y. and Milne, G.W.A. (1997) Discovery of Hiv-1 Integrase Inhibitors by Pharmacophore Searching. Journal of Medicinal Chemistry, 40, 930-936. http://dx.doi.org/10.1021/jm960754h

[28] Neamati, N., Hong, H., Owen, J.M., Sunder, S., Winslow, H.E., Christensen, J.L., Zhao, H., Burke, T.R., Jr., Milne, G.W. and Pommier, Y. (1998) Salicylhydrazine-Containing Inhibitors of Hiv-1 Integrase: Implication for a Selective Chelation in the Integrase Active Site. Journal of Medicinal Chemistry, 41, 3202-3209. http://dx.doi.org/10.1021/jm9801760

[29] Hong, H., Neamati, N., Winslow, H.E., Christensen, J.L., Orr, A., Pommier, Y. and Milne, G.W. (1998) Identification of Hiv-1 Integrase Inhibitors Based on a Four-Point Pharmacophore. Antiviral Chemistry \& Chemotherapy, 9, 461-472. http://dx.doi.org/10.1177/095632029800900602

[30] Hong, H., Fang, H., Xie, Q., Perkins, R., Sheehan, D.M. and Tong, W. (2003) Comparative Molecular Field Analysis (Comfa) Model Using a Large Diverse Set of Natural, Synthetic and Environmental Chemicals for Binding to the Androgen Receptor. SAR and QSAR in Environmental Research, 14, 373-388. http://dx.doi.org/10.1080/10629360310001623962

[31] Shi, L., Tong, W., Fang, H., Xie, Q., Hong, H., Perkins, R., Wu, J., Tu, M., Blair, R.M., Branham, W.S., Waller, C., Walker, J. and Sheehan, D.M. (2002) An Integrated “4-Phase” Approach for Setting Endocrine Disruption Screening Priorities-Phase I and Ii Predictions of Estrogen Receptor Binding Affinity. SAR and QSAR in Environmental Research, 13, 69-88. http://dx.doi.org/10.1080/10629360290002235

[32] Liu, J., Mansouri, K., Judson, R., Martin, M.T., Hong, H., Chen, M., Xu, X., Thomas, R. and Shah, I. (2015) Predicting Hepatotoxicity Using ToxCast in Vitro Bioactivity and Chemical Structure. Chemical Research in Toxicology, 28, 738-751http://dx.doi.org/10.1021/tx500501h

[33] Hong, H., Tong, W., Fang, H., Shi, L., Xie, Q., Wu, J., Perkins, R., Walker, J.D., Branham, W. and Sheehan, D.M. (2002) Prediction of Estrogen Receptor Binding for 58,000 Chemicals Using an Integrated System of a Tree-Based Model with Structural Alerts. Environmental Health Perspectives, 110, 29-36. http://dx.doi.org/10.1289/ehp.0211029 
[34] Hong, H., Tong, W., Perkins, R., Fang, H., Xie, Q. and Shi, L. (2004) Multiclass Decision Forest-a Novel Pattern Recognition Method for Multiclass Classification in Microarray Data Analysis. DNA and Cell Biology, 23, 685-694. http://dx.doi.org/10.1089/dna.2004.23.685

[35] Hong, H., Tong, W., Xie, Q., Fang, H. and Perkins, R. (2005) An in Silico Ensemble Method for Lead Discovery: Decision Forest. SAR and QSAR in Environmental Research, 16, 339-347. http://dx.doi.org/10.1080/10659360500203022

[36] Tong, W., Hong, H., Fang, H., Xie, Q. and Perkins, R. (2003) Decision Forest: Combining the Predictions of Multiple Independent Decision Tree Models. Journal of Chemical Information and Computer Science, 43, 525-531. http://dx.doi.org/10.1021/ci020058s

[37] Tong, W., Xie, Q., Hong, H., Shi, L., Fang, H., Perkins, R. and Petricoin, E.F. (2004) Using Decision Forest to Classify Prostate Cancer Samples on the Basis of Seldi-Tof Ms Data: Assessing Chance Correlation and Prediction Confidence. Environmental Health Perspectives, 112, 1622-1627. http://dx.doi.org/10.1289/ehp.7109

[38] Xie, Q., Ratnasinghe, L.D., Hong, H., Perkins, R., Tang, Z.Z., Hu, N., Taylor, P.R. and Tong, W. (2005) Decision Forest Analysis of 61 Single Nucleotide Polymorphisms in a Case-Control Study of Esophageal Cancer; a Novel Method. BMC Bioinformatics, 6, S4. http://dx.doi.org/10.1186/1471-2105-6-S2-S4

[39] Ng, H.W., Doughty, S.W., Luo, H., Ye, H., Ge, W., Tong, W. and Hong, H. (2015) Development and Validation of Decision Forest Model for Estrogen Receptor Binding Prediction of Chemicals Using Large Data Sets. Chemical Research in Toxicology, 28, 2343-2351. http://dx.doi.org/10.1021/acs.chemrestox.5b00358

[40] McPhail, B., Tie, Y., Hong, H., Pearce, B.A., Schnackenberg, L.K., Ge, W., Valerio, L.G., Fuscoe, J.C., Tong, W., Buzatu, D.A., et al. (2012) Modeling Chemical Interaction Profiles: I. Spectral Data-Activity Relationship and Structure-Activity Relationship Models for Inhibitors and Non-Inhibitors of Cytochrome P450 CYP3A4 and CYP2D6 Isozymes. Molecules, 17, 3283-3406. http://dx.doi.org/10.3390/molecules17033383

[41] Tong, W., Hong, H., Xie, Q., Shi, L., Fang, H. and Perkins, R. (2005) Assessing QSAR limitations-A Regulatory Perspective. Current Computer-Aided Drug Design, 1, 195-205. http://dx.doi.org/10.2174/1573409053585663

[42] Hong, H., Xie, Q., Ge, W., Qian, F., Fang, H., Shi, L., Su, Z., Perkins, R. and Tong, W. (2008) Mold(2), Molecular Descriptors from 2d Structures for Chemoinformatics and Toxicoinformatics. Journal of Chemical Information and Modeling, 48, 1337-1344. http://dx.doi.org/10.1021/ci800038f

[43] Hong, H. and Xin, X. (1990) ESSESA: An Expert System for Structure Elucidation from Spectra Analysis. 1. The Knowledge Base of Infrared Spectra and Analysis and Interpretation Program. Journal of Chemical Information and Modeling, 30, 203-210. http://dx.doi.org/10.1021/ci00067a001

[44] Hong, H. and Xin, X. (1992) ESSESA: An Expert System for Structure Elucidation from Spectra Analysis. 2. A Novel Algorithm of Perception of the Linear Independent Smallest Set of Smallest Rings. Analytica Chimica Acta, 262, 179191. http://dx.doi.org/10.1016/0003-2670(92)80022-Y

[45] Hong, H. and Xin, X. (1992) ESSESA: An Expert System for Structure Elucidation from Spectra Analysis. 3. LNSCS for Chemical Knowledge Representation. Journal of Chemical Information and Modeling, 32, 116-120. http://dx.doi.org/10.1021/ci00005a019

[46] Hong, H. and Xin, X. (1994) ESSESA: An Expert System for Structure Elucidation from Spectra Analysis. 4. Canonical Representation of Structures. Journal of Chemical Information and Modeling, 34, 730-734. http://dx.doi.org/10.1021/ci00020a006

[47] Hong, H. and Xin, X. (1994) ESSESA: An Expert System for Structure Elucidation from Spectra Analysis. 5. Substructure Constraints from Analysis of First-Order 1H-NMR Spectra. Journal of Chemical Information and Modeling, 34, 1259-1266. http://dx.doi.org/10.1021/ci00022a006

[48] Hong, H., Han, Y., Xin, X. and Shi, Y. (1995) ESSESA: An Expert System for Structure Elucidation from Spectra Analysis. 6. Substructure Constraints from Analysis of First-Order 13C-NMR Spectra. Journal of Chemical Information and Modeling, 35, 979-1000. http://dx.doi.org/10.1021/ci00028a005

[49] Masui, H. and Hong, H. (2006) Spec2D: A Structure Elucidation System Based on 1H NMR and H-H COSY Spectra in Organic Chemistry. Journal of Chemical Information and Modeling, 46, 775-787. http://dx.doi.org/10.1021/ci0502810

[50] Drake, R.R., Neamati, N., Hong, H., Pilon, A., Sunthankar, P., Hume, S.D., Wilne, G.W.A. and Pommier, Y. (1998) Identification of a Mononucleotide Binding Site in Human HIV-1 Integrase. Proceedings of the National Academy of Sciences USA, 98, 1495-1500.

[51] Tie, Y., McPhail, B., Hong, H., Pearce, B.A., Schnackenberg, L.K., Ge, W., Buzatu, D.A., Wilkes, J.G., Fuscoe, J.C., Tong, W., et al. (2012) Modeling Chemical Interaction Profiles: II. Molecular Docking, Spectral Data-Activity Relationship, and Structure-Activity Relationship Models for Potent and Weak Inhibitors of Cytochrome p450 cyp3A4 Isozyme. Molecules, 17, 3407-3460. http://dx.doi.org/10.3390/molecules17033407

[52] Ng, H.W., Perkins, R., Tong, W. and Hong, H. (2014) Versatility or Promiscuity: The Estrogen Receptors, Control of 
Ligand Selectivity and an Update on Subtype Selective Ligands. International Journal of Environmental Research and Public Health, 11, 8709-8742. http://dx.doi.org/10.3390/ijerph110908709

[53] Ng, H.W., Shu, M., Luo, H., Ye, H., Ge, W., Perkins, R., Tong, W. and Hong, H. (2015) Estrogenic Activity Data Extraction and in Silico Prediction Show the Endocrine Disruption Potential of Bisphenol a Replacement Compounds. Chemical Research in Toxicology, 28, 1784-1795. http://dx.doi.org/10.1021/acs.chemrestox.5b00243

[54] Shen, J., Xu, L., Fang, H., Richard, A.M., Bray, J.D., Judson, R.S., Zhou, G., Colatsky, T.J., Aungst, J.L., Teng, C., Harris, S.C., Ge, W., Dai, S.Y., Su, Z., Jacobs, A.C., Harrouk, W., Perkins, R., Tong, W. and Hong, H. (2013) EADB: An Estrogenic Activity Database for Assessing Potential Endocrine Activity. Toxicological Sciences, 135, $277-291$. http://dx.doi.org/10.1093/toxsci/kft164

[55] Ding, D., Xu, L., Fang, H., Hong, H., Perkins, R., Harris, S., Bearden, E.D., Shi, L. and Tong, W. (2010) The Edkb: An Established Knowledge Base for Endocrine Disrupting Chemicals. BMC Bioinformatics, 11, S5. http://dx.doi.org/10.1186/1471-2105-11-S6-S5

[56] Amber (2010) Version 11 University of California, San Francisco.

[57] Lindorff-Larsen, K., Piana, S., Palmo, K., Maragakis, P., Klepeis, J.L., Dror, R.O. and Shaw, D.E. (2010) Improved Side-Chain Torsion Potentials for the Amber Ff99sb Protein Force Field. Proteins: Structure, Function, and Bioinformatics, 78, 1950-1958. http://dx.doi.org/10.1002/prot.22711

[58] Wang, J., Wolf, R.M., Caldwell, J.W., Kollman, P.A. and Case, D.A. (2004) Development and Testing of a General Amber Force Field. Journal of Computational Chemistry, 25, 1157-1174. http://dx.doi.org/10.1002/jcc.20035

[59] Jakalian, A., Jack, D.B. and Bayly, C.I. (2002) Fast, Efficient Generation of High-Quality Atomic Charges. Am1-Bcc Model: Ii. Parameterization and Validation. Journal of Computational Chemistry, 23, 1623-1641. http://dx.doi.org/10.1002/jcc.10128

[60] Ryckaert, J.-P., Ciccotti, G. and Berendsen, H.J. (1977) Numerical Integration of the Cartesian Equations of Motion of a System with Constraints: Molecular Dynamics of n-Alkanes. Journal of Computational Physics, 23, 327-341. http://dx.doi.org/10.1016/0021-9991(77)90098-5

[61] Darden, T., York, D. and Pedersen, L. (1993) Particle Mesh Ewald: An N·Log (N) Method for Ewald Sums in Large Systems. The Journal of Chemical Physics, 98, 10089-10092. http://dx.doi.org/10.1063/1.464397

[62] Rost, B. (1999) Twilight Zone of Protein Sequence Alignments. Protein Engineering, 12, 85-94. http://dx.doi.org/10.1093/protein/12.2.85

[63] Yang, A.-S. and Honig, B. (2000) An Integrated Approach to the Analysis and Modeling of Protein Sequences and Structures. Iii. A Comparative Study of Sequence Conservation in Protein Structural Families Using Multiple Structural Alignments. Journal of Molecular Biology, 301, 691-711. http://dx.doi.org/10.1006/jmbi.2000.3975

[64] Raval, A., Piana, S., Eastwood, M.P., Dror, R.O. and Shaw, D.E. (2012) Refinement of Protein Structure Homology Models Via Long, All-Atom Molecular Dynamics Simulations. Proteins: Structure, Function, and Bioinformatics, 80, 2071-2079. http://dx.doi.org/10.1002/prot.24098

[65] Cheng, X., Wang, H., Grant, B., Sine, S.M. and McCammon, J.A. (2006) Targeted Molecular Dynamics Study of C-Loop Closure and Channel Gating in Nicotinic Receptors. PLoS Computational Biology, 2, e134. http://dx.doi.org/10.1371/journal.pcbi.0020134

[66] Liu, X., Xu, Y., Li, H., Wang, X., Jiang, H. and Barrantes, F.J. (2008) Mechanics of Channel Gating of the Nicotinic Acetylcholine Receptor. PLoS Computational Biology, 4, e19. http://dx.doi.org/10.1371/journal.pcbi.0040019

[67] Cheng, M.H., Xu, Y. and Tang, P. (2009) Anionic Lipid and Cholesterol Interactions with $A 4 \beta 2$ Nachr: Insights from Md Simulations. The Journal of Physical Chemistry B, 113, 6964-6970. http://dx.doi.org/10.1021/jp900714b

[68] Liu, L.T., Haddadian, E.J., Willenbring, D., Xu, Y. and Tang, P. (2009) Higher Susceptibility to Halothane Modulation in Open-Than in Closed-Channel $A 4 \beta 2$ Nachr Revealed by Molecular Dynamics Simulations. The Journal of Physical Chemistry B, 114, 626-632. http://dx.doi.org/10.1021/jp908944e

[69] Shu, M., Lin, Z., Zhang, Y., Wu, Y., Mei, H. and Jiang, Y. (2011) Molecular Dynamics Simulation of Oseltamivir Resistance in Neuraminidase of Avian Influenza H5n1 Virus. Journal of Molecular Modeling, 17, 587-592. http://dx.doi.org/10.1007/s00894-010-0757-x

[70] Halgren, T. (2007) New Method for Fast and Accurate Binding-Site Identification and Analysis. Chemical Biology \& Drug Design, 69, 146-8. http://dx.doi.org/10.1111/j.1747-0285.2007.00483.x

[71] Sousa, S.F., Fernandes, P.A. and Ramos, M.J. (2006) Protein-Ligand Docking: Current Status and Future Challenges. Proteins, 65, 15-26. http://dx.doi.org/10.1002/prot.21082

[72] Cheng, T., Li, Q., Zhou, Z., Wang, Y. and Bryant, S.H. (2012) Structure-Based Virtual Screening for Drug Discovery: A Problem-Centric Review. AAPS Journal, 14, 133-141. http://dx.doi.org/10.1208/s12248-012-9322-0

[73] Celie, P.H., van Rossum-Fikkert, S.E., van Dijk, W.J., Brejc, K., Smit, A.B. and Sixma, T.K. (2004) Nicotine and 
Carbamylcholine Binding to Nicotinic Acetylcholine Receptors as Studied in Achbp Crystal Structures. Neuron, 41, 907-914. http://dx.doi.org/10.1016/S0896-6273(04)00115-1

[74] Ihara, M., Okajima, T., Yamashita, A., Oda, T., Hirata, K., Nishiwaki, H., Morimoto, T., Akamatsu, M., Ashikawa, Y. and Kuroda, S.I. (2008) Crystal Structures of Lymnaea Stagnalis Achbp in Complex with Neonicotinoid Insecticides Imidacloprid and Clothianidin. Invertebrate Neuroscience, 8, 71-81. http://dx.doi.org/10.1007/s10158-008-0069-3

[75] Rohde, L.A.H., Ahring, P.K., Jensen, M.L., Nielsen, E.O., Peters, D., Helgstrand, C., Krintel, C., Harpsoe, K., Gajhede, M., Kastrup, J.S. and Balle, T. (2012) Intersubunit Bridge Formation Governs Agonist Efficacy at Nicotinic Acetylcholine Alpha 4 Beta 2 Receptors Unique Role of Halogen Bonding Revealed. Journal of Biological Chemistry, 287, 4248-4259. http://dx.doi.org/10.1074/jbc.M111.292243

[76] Rucktooa, P., Haseler, C.A., van Elk, R., Smit, A.B., Gallagher, T. and Sixma, T.K. (2012) Structural Characterization of Binding Mode of Smoking Cessation Drugs to Nicotinic Acetylcholine Receptors through Study of Ligand Complexes with Acetylcholine-Binding Protein. Journal of Biological Chemistry, 287, 23283-23293. http://dx.doi.org/10.1074/jbc.M112.360347

[77] Xiu, X., Puskar, N.L., Shanata, J.A., Lester, H.A. and Dougherty, D.A. (2009) Nicotine Binding to Brain Receptors Requires a Strong Cation- $\pi$ Interaction. Nature, 458, 534-537. http://dx.doi.org/10.1038/nature07768 


\section{Supplementary Material}

Table S1. Information on the 11 ligands used in this study.

\begin{tabular}{|c|c|c|c|}
\hline ID & Compound & PDB ID & pKi \\
\hline NCT & L-(-)-nicotine & 1UW6 & 8.34 \\
\hline IM4 & Imidacloprid & $2 \mathrm{ZJU}$ & 9.21 \\
\hline 090 & 1-(pyridin-3-yl)-1,4-diazepane & 3U8J & 9.14 \\
\hline 09P & 1-(5-ethoxypyridin-3-yl)-1,4-diazepane & $3 \mathrm{U} 8 \mathrm{~K}$ & 9.21 \\
\hline 09Q & 1-(5-phenylpyridin-3-yl)-1,4-diazepane & 3U8L & 9.10 \\
\hline 09R & 1-(6-bromopyridin-3-yl)-1,4-diazepane & $3 \mathrm{U} 8 \mathrm{M}$ & 9.49 \\
\hline 09S & 1-(6-bromo-5-ethoxypyridin-3-yl)-1,4-diazepane & $3 \mathrm{U} 8 \mathrm{~N}$ & 9.60 \\
\hline L0B & Alpha-lobeline & $4 \mathrm{AFH}$ & 8.15 \\
\hline QMR & Varenicline & $4 \mathrm{AFT}$ & 10.30 \\
\hline SW4 & 2-[(1R,2S)-2-[5-[[(2S)-azetidin-2-yl]methoxy]pyridin- 3-yl]cyclopropyl]ethanol & $4 \mathrm{~B} 5 \mathrm{D}$ & 10.00 \\
\hline C5E & Cytisine & 4BQT & 9.77 \\
\hline
\end{tabular}

Table S2. Results of search a4 subunit on the PDB. ID consists of PDB ID (the first 4 letters) and the subunit (the last letter).

\begin{tabular}{|c|c|c|c|c|c|c|}
\hline ID & Score & Expect & Identity & Positives & Gaps & Resolution \\
\hline 2WN9_A & 87.8 & $1.20 \mathrm{E}-20$ & $28 \%$ & $43 \%$ & $2 \%$ & 1.75 \\
\hline 2WN9_B & 87.8 & $1.20 \mathrm{E}-20$ & $28 \%$ & $43 \%$ & $2 \%$ & 1.75 \\
\hline 2WN9_C & 87.8 & $1.20 \mathrm{E}-20$ & $28 \%$ & $43 \%$ & $2 \%$ & 1.75 \\
\hline 2WN9_D & 87.8 & $1.20 \mathrm{E}-20$ & $28 \%$ & $43 \%$ & $2 \%$ & 1.75 \\
\hline 2WN9_E & 87.8 & $1.20 \mathrm{E}-20$ & $28 \%$ & $43 \%$ & $2 \%$ & 1.75 \\
\hline 2PGZ_A & 87.8 & $1.10 \mathrm{E}-20$ & $28 \%$ & $43 \%$ & $2 \%$ & 1.76 \\
\hline 2PGZ_B & 87.8 & $1.10 \mathrm{E}-20$ & $28 \%$ & $43 \%$ & $2 \%$ & 1.76 \\
\hline 2PGZ_C & 87.8 & $1.10 \mathrm{E}-20$ & $28 \%$ & $43 \%$ & $2 \%$ & 1.76 \\
\hline 2PGZ_D & 87.8 & $1.10 \mathrm{E}-20$ & $28 \%$ & $43 \%$ & $2 \%$ & 1.76 \\
\hline 2PGZ_E & 87.8 & $1.10 \mathrm{E}-20$ & $28 \%$ & $43 \%$ & $2 \%$ & 1.76 \\
\hline 2WNJ_A & 87.8 & $1.20 \mathrm{E}-20$ & $28 \%$ & $43 \%$ & $2 \%$ & 1.8 \\
\hline 2WNJ_B & 87.8 & $1.20 \mathrm{E}-20$ & $28 \%$ & $43 \%$ & $2 \%$ & 1.8 \\
\hline 2WNJ_C & 87.8 & $1.20 \mathrm{E}-20$ & $28 \%$ & $43 \%$ & $2 \%$ & 1.8 \\
\hline 2WNJ_D & 87.8 & $1.20 \mathrm{E}-20$ & $28 \%$ & $43 \%$ & $2 \%$ & 1.8 \\
\hline 2WNJ_E & 87.8 & $1.20 \mathrm{E}-20$ & $28 \%$ & $43 \%$ & $2 \%$ & 1.8 \\
\hline 4AFH_A & 99.8 & $6.30 \mathrm{E}-25$ & $31 \%$ & $48 \%$ & $7 \%$ & 1.88 \\
\hline 4AFH_B & 99.8 & $6.30 \mathrm{E}-25$ & $31 \%$ & $48 \%$ & $7 \%$ & 1.88 \\
\hline 4AFH_C & 99.8 & $6.30 \mathrm{E}-25$ & $31 \%$ & $48 \%$ & $7 \%$ & 1.88 \\
\hline 4AFH_D & 99.8 & $6.30 \mathrm{E}-25$ & $31 \%$ & $48 \%$ & $7 \%$ & 1.88 \\
\hline 4AFH_E & 99.8 & $6.30 \mathrm{E}-25$ & $31 \%$ & $48 \%$ & $7 \%$ & 1.88 \\
\hline 2Y7Y_A & 89.4 & $3.00 \mathrm{E}-21$ & $29 \%$ & $43 \%$ & $2 \%$ & 1.9 \\
\hline
\end{tabular}




\section{Continued}

\begin{tabular}{|c|c|c|c|c|c|c|}
\hline 2Y7Y_B & 89.4 & $3.00 \mathrm{E}-21$ & $29 \%$ & $43 \%$ & $2 \%$ & 1.9 \\
\hline 2Y7Y_C & 89.4 & $3.00 \mathrm{E}-21$ & $29 \%$ & $43 \%$ & $2 \%$ & 1.9 \\
\hline 2Y7Y_D & 89.4 & $3.00 \mathrm{E}-21$ & $29 \%$ & $43 \%$ & $2 \%$ & 1.9 \\
\hline 2Y7Y_E & 89.4 & $3.00 \mathrm{E}-21$ & $29 \%$ & $43 \%$ & $2 \%$ & 1.9 \\
\hline 2XYS_A & 89.4 & $3.00 \mathrm{E}-21$ & $29 \%$ & $43 \%$ & $2 \%$ & 1.909 \\
\hline 2XYS_B & 89.4 & $3.00 \mathrm{E}-21$ & $29 \%$ & $43 \%$ & $2 \%$ & 1.909 \\
\hline 2XYS_C & 89.4 & $3.00 \mathrm{E}-21$ & $29 \%$ & $43 \%$ & $2 \%$ & 1.909 \\
\hline 2XYS_D & 89.4 & $3.00 \mathrm{E}-21$ & $29 \%$ & $43 \%$ & $2 \%$ & 1.909 \\
\hline 2XYS_E & 89.4 & $3.00 \mathrm{E}-21$ & $29 \%$ & $43 \%$ & $2 \%$ & 1.909 \\
\hline 3C84_A & 87.8 & $1.00 \mathrm{E}-20$ & $28 \%$ & $43 \%$ & $2 \%$ & 1.94 \\
\hline 3C84_B & 87.8 & $1.00 \mathrm{E}-20$ & $28 \%$ & $43 \%$ & $2 \%$ & 1.94 \\
\hline 3C84_C & 87.8 & $1.00 \mathrm{E}-20$ & $28 \%$ & $43 \%$ & $2 \%$ & 1.94 \\
\hline 3C84_D & 87.8 & $1.00 \mathrm{E}-20$ & $28 \%$ & $43 \%$ & $2 \%$ & 1.94 \\
\hline 3C84_E & 87.8 & $1.00 \mathrm{E}-20$ & $28 \%$ & $43 \%$ & $2 \%$ & 1.94 \\
\hline 2QC1_B & 217.6 & $1.90 \mathrm{E}-70$ & $52 \%$ & $66 \%$ & $0 \%$ & 1.94 \\
\hline 2YMD_A & 90.1 & $1.30 \mathrm{E}-21$ & $28 \%$ & $42 \%$ & $2 \%$ & 1.96 \\
\hline 2YMD_B & 90.1 & $1.30 \mathrm{E}-21$ & $28 \%$ & $42 \%$ & $2 \%$ & 1.96 \\
\hline 2YMD_C & 90.1 & $1.30 \mathrm{E}-21$ & $28 \%$ & $42 \%$ & $2 \%$ & 1.96 \\
\hline 2YMD_D & 90.1 & $1.30 \mathrm{E}-21$ & $28 \%$ & $42 \%$ & $2 \%$ & 1.96 \\
\hline 2YMD_E & 90.1 & $1.30 \mathrm{E}-21$ & $28 \%$ & $42 \%$ & $2 \%$ & 1.96 \\
\hline 2YMD_F & 90.1 & $1.30 \mathrm{E}-21$ & $28 \%$ & $42 \%$ & $2 \%$ & 1.96 \\
\hline 2YMD_G & 90.1 & $1.30 \mathrm{E}-21$ & $28 \%$ & $42 \%$ & $2 \%$ & 1.96 \\
\hline 2YMD_H & 90.1 & $1.30 \mathrm{E}-21$ & $28 \%$ & $42 \%$ & $2 \%$ & 1.96 \\
\hline 2YMD_I & 90.1 & $1.30 \mathrm{E}-21$ & $28 \%$ & $42 \%$ & $2 \%$ & 1.96 \\
\hline 2YMD_J & 90.1 & $1.30 \mathrm{E}-21$ & $28 \%$ & $42 \%$ & $2 \%$ & 1.96 \\
\hline 2BJ0_A & 60.5 & $2.50 \mathrm{E}-11$ & $22 \%$ & $43 \%$ & $3 \%$ & 2 \\
\hline 2BJ0_B & 60.5 & $2.50 \mathrm{E}-11$ & $22 \%$ & $43 \%$ & $3 \%$ & 2 \\
\hline 2BJ0_C & 60.5 & $2.50 \mathrm{E}-11$ & $22 \%$ & $43 \%$ & $3 \%$ & 2 \\
\hline 2BJ0_D & 60.5 & $2.50 \mathrm{E}-11$ & $22 \%$ & $43 \%$ & $3 \%$ & 2 \\
\hline 2BJ0_E & 60.5 & $2.50 \mathrm{E}-11$ & $22 \%$ & $43 \%$ & $3 \%$ & 2 \\
\hline 1A05_A & 30.4 & 1.2 & $26 \%$ & $43 \%$ & $21 \%$ & 2 \\
\hline 1A05_B & 30.4 & 1.2 & $26 \%$ & $43 \%$ & $21 \%$ & 2 \\
\hline 4AFG_A & 99.8 & $6.30 \mathrm{E}-25$ & $31 \%$ & $48 \%$ & $7 \%$ & 2 \\
\hline 4AFG_B & 99.8 & $6.30 \mathrm{E}-25$ & $31 \%$ & $48 \%$ & $7 \%$ & 2 \\
\hline 4AFG_C & 99.8 & $6.30 \mathrm{E}-25$ & $31 \%$ & $48 \%$ & $7 \%$ & 2 \\
\hline 4AFG_D & 99.8 & $6.30 \mathrm{E}-25$ & $31 \%$ & $48 \%$ & $7 \%$ & 2 \\
\hline 4AFG_E & 99.8 & $6.30 \mathrm{E}-25$ & $31 \%$ & $48 \%$ & $7 \%$ & 2 \\
\hline
\end{tabular}




\section{Continued}

\begin{tabular}{|c|c|c|c|c|c|c|}
\hline 2BYN_A & 87.8 & $1.00 \mathrm{E}-20$ & $28 \%$ & $43 \%$ & $2 \%$ & 2.02 \\
\hline 2BYN_B & 87.8 & $1.00 \mathrm{E}-20$ & $28 \%$ & $43 \%$ & $2 \%$ & 2.02 \\
\hline 2BYN_C & 87.8 & $1.00 \mathrm{E}-20$ & $28 \%$ & $43 \%$ & $2 \%$ & 2.02 \\
\hline 2BYN_D & 87.8 & $1.00 \mathrm{E}-20$ & $28 \%$ & $43 \%$ & $2 \%$ & 2.02 \\
\hline 2BYN_E & 87.8 & $1.00 \mathrm{E}-20$ & $28 \%$ & $43 \%$ & $2 \%$ & 2.02 \\
\hline 2BYS_A & 87.8 & $1.00 \mathrm{E}-20$ & $28 \%$ & $43 \%$ & $2 \%$ & 2.05 \\
\hline 2BYS_B & 87.8 & $1.00 \mathrm{E}-20$ & $28 \%$ & $43 \%$ & $2 \%$ & 2.05 \\
\hline 2BYS_C & 87.8 & $1.00 \mathrm{E}-20$ & $28 \%$ & $43 \%$ & $2 \%$ & 2.05 \\
\hline 2BYS_D & 87.8 & $1.00 \mathrm{E}-20$ & $28 \%$ & $43 \%$ & $2 \%$ & 2.05 \\
\hline 2BYS_E & 87.8 & $1.00 \mathrm{E}-20$ & $28 \%$ & $43 \%$ & $2 \%$ & 2.05 \\
\hline 2BYS_F & 87.8 & $1.00 \mathrm{E}-20$ & $28 \%$ & $43 \%$ & $2 \%$ & 2.05 \\
\hline 2BYS_G & 87.8 & $1.00 \mathrm{E}-20$ & $28 \%$ & $43 \%$ & $2 \%$ & 2.05 \\
\hline 2BYS_H & 87.8 & $1.00 \mathrm{E}-20$ & $28 \%$ & $43 \%$ & $2 \%$ & 2.05 \\
\hline 2BYS_I & 87.8 & $1.00 \mathrm{E}-20$ & $28 \%$ & $43 \%$ & $2 \%$ & 2.05 \\
\hline 2BYS_J & 87.8 & $1.00 \mathrm{E}-20$ & $28 \%$ & $43 \%$ & $2 \%$ & 2.05 \\
\hline 2XYT_A & 89.4 & $3.00 \mathrm{E}-21$ & $29 \%$ & $43 \%$ & $2 \%$ & 2.05 \\
\hline 2XYT_B & 89.4 & $3.00 \mathrm{E}-21$ & $29 \%$ & $43 \%$ & $2 \%$ & 2.05 \\
\hline 2XYT_C & 89.4 & $3.00 \mathrm{E}-21$ & $29 \%$ & $43 \%$ & $2 \%$ & 2.05 \\
\hline 2XYT_D & 89.4 & $3.00 \mathrm{E}-21$ & $29 \%$ & $43 \%$ & $2 \%$ & 2.05 \\
\hline 2XYT_E & 89.4 & $3.00 \mathrm{E}-21$ & $29 \%$ & $43 \%$ & $2 \%$ & 2.05 \\
\hline 2XYT_F & 89.4 & $3.00 \mathrm{E}-21$ & $29 \%$ & $43 \%$ & $2 \%$ & 2.05 \\
\hline 2XYT_G & 89.4 & $3.00 \mathrm{E}-21$ & $29 \%$ & $43 \%$ & $2 \%$ & 2.05 \\
\hline 2XYT_H & 89.4 & $3.00 \mathrm{E}-21$ & $29 \%$ & $43 \%$ & $2 \%$ & 2.05 \\
\hline 2XYT_I & 89.4 & $3.00 \mathrm{E}-21$ & $29 \%$ & $43 \%$ & $2 \%$ & 2.05 \\
\hline 2XYT_J & 89.4 & $3.00 \mathrm{E}-21$ & $29 \%$ & $43 \%$ & $2 \%$ & 2.05 \\
\hline 2BYP_A & 88.2 & $6.80 \mathrm{E}-21$ & $28 \%$ & $43 \%$ & $2 \%$ & 2.07 \\
\hline 2BYP_B & 88.2 & $6.80 \mathrm{E}-21$ & $28 \%$ & $43 \%$ & $2 \%$ & 2.07 \\
\hline 2BYP_C & 88.2 & $6.80 \mathrm{E}-21$ & $28 \%$ & $43 \%$ & $2 \%$ & 2.07 \\
\hline 2BYP_D & 88.2 & $6.80 \mathrm{E}-21$ & $28 \%$ & $43 \%$ & $2 \%$ & 2.07 \\
\hline 2BYP_E & 88.2 & $6.80 \mathrm{E}-21$ & $28 \%$ & $43 \%$ & $2 \%$ & 2.07 \\
\hline 3PEO_A & 87.8 & $1.20 \mathrm{E}-20$ & $28 \%$ & $43 \%$ & $2 \%$ & 2.1 \\
\hline 3PEO_B & 87.8 & $1.20 \mathrm{E}-20$ & $28 \%$ & $43 \%$ & $2 \%$ & 2.1 \\
\hline 3PEO_C & 87.8 & $1.20 \mathrm{E}-20$ & $28 \%$ & $43 \%$ & $2 \%$ & 2.1 \\
\hline 3PEO_D & 87.8 & $1.20 \mathrm{E}-20$ & $28 \%$ & $43 \%$ & $2 \%$ & 2.1 \\
\hline 3PEO_E & 87.8 & $1.20 \mathrm{E}-20$ & $28 \%$ & $43 \%$ & $2 \%$ & 2.1 \\
\hline 3PEO_F & 87.8 & $1.20 \mathrm{E}-20$ & $28 \%$ & $43 \%$ & $2 \%$ & 2.1 \\
\hline 3PEO_G & 87.8 & $1.20 \mathrm{E}-20$ & $28 \%$ & $43 \%$ & $2 \%$ & 2.1 \\
\hline
\end{tabular}




\section{Continued}

\begin{tabular}{|c|c|c|c|c|c|c|}
\hline 3PEO_H & 87.8 & $1.20 \mathrm{E}-20$ & $28 \%$ & $43 \%$ & $2 \%$ & 2.1 \\
\hline 3PEO_I & 87.8 & $1.20 \mathrm{E}-20$ & $28 \%$ & $43 \%$ & $2 \%$ & 2.1 \\
\hline 3PEO_J & 87.8 & $1.20 \mathrm{E}-20$ & $28 \%$ & $43 \%$ & $2 \%$ & 2.1 \\
\hline 1UW6_A & 63.5 & $2.20 \mathrm{E}-12$ & $26 \%$ & $41 \%$ & $7 \%$ & 2.2 \\
\hline 1UW6_B & 63.5 & $2.20 \mathrm{E}-12$ & $26 \%$ & $41 \%$ & $7 \%$ & 2.2 \\
\hline 1UW6_C & 63.5 & $2.20 \mathrm{E}-12$ & $26 \%$ & $41 \%$ & $7 \%$ & 2.2 \\
\hline 1UW6_D & 63.5 & $2.20 \mathrm{E}-12$ & $26 \%$ & $41 \%$ & $7 \%$ & 2.2 \\
\hline 1UW6_E & 63.5 & $2.20 \mathrm{E}-12$ & $26 \%$ & $41 \%$ & $7 \%$ & 2.2 \\
\hline 1UW6_F & 63.5 & $2.20 \mathrm{E}-12$ & $26 \%$ & $41 \%$ & $7 \%$ & 2.2 \\
\hline 1UW6_G & 63.5 & $2.20 \mathrm{E}-12$ & $26 \%$ & $41 \%$ & $7 \%$ & 2.2 \\
\hline 1UW6_H & 63.5 & $2.20 \mathrm{E}-12$ & $26 \%$ & $41 \%$ & $7 \%$ & 2.2 \\
\hline 1UW6_I & 63.5 & $2.20 \mathrm{E}-12$ & $26 \%$ & $41 \%$ & $7 \%$ & 2.2 \\
\hline 1UW6_J & 63.5 & $2.20 \mathrm{E}-12$ & $26 \%$ & $41 \%$ & $7 \%$ & 2.2 \\
\hline 1UW6_K & 63.5 & $2.20 \mathrm{E}-12$ & $26 \%$ & $41 \%$ & $7 \%$ & 2.2 \\
\hline 1UW6_L & 63.5 & $2.20 \mathrm{E}-12$ & $26 \%$ & $41 \%$ & $7 \%$ & 2.2 \\
\hline 1UW6_M & 63.5 & $2.20 \mathrm{E}-12$ & $26 \%$ & $41 \%$ & $7 \%$ & 2.2 \\
\hline 1UW6_N & 63.5 & $2.20 \mathrm{E}-12$ & $26 \%$ & $41 \%$ & $7 \%$ & 2.2 \\
\hline 1UW6_O & 63.5 & $2.20 \mathrm{E}-12$ & $26 \%$ & $41 \%$ & $7 \%$ & 2.2 \\
\hline 1UW6_P & 63.5 & $2.20 \mathrm{E}-12$ & $26 \%$ & $41 \%$ & $7 \%$ & 2.2 \\
\hline 1UW6_Q & 63.5 & $2.20 \mathrm{E}-12$ & $26 \%$ & $41 \%$ & $7 \%$ & 2.2 \\
\hline 1UX2_A & 63.5 & $2.40 \mathrm{E}-12$ & $26 \%$ & $41 \%$ & $7 \%$ & 2.2 \\
\hline 1UX2_B & 63.5 & $2.40 \mathrm{E}-12$ & $26 \%$ & $41 \%$ & $7 \%$ & 2.2 \\
\hline 1UX2_C & 63.5 & $2.40 \mathrm{E}-12$ & $26 \%$ & $41 \%$ & $7 \%$ & 2.2 \\
\hline 1UX2_D & 63.5 & $2.40 \mathrm{E}-12$ & $26 \%$ & $41 \%$ & $7 \%$ & 2.2 \\
\hline 1UX2_E & 63.5 & $2.40 \mathrm{E}-12$ & $26 \%$ & $41 \%$ & $7 \%$ & 2.2 \\
\hline 1UX2_F & 63.5 & $2.40 \mathrm{E}-12$ & $26 \%$ & $41 \%$ & $7 \%$ & 2.2 \\
\hline 1UX2_G & 63.5 & $2.40 \mathrm{E}-12$ & $26 \%$ & $41 \%$ & $7 \%$ & 2.2 \\
\hline 1UX2_H & 63.5 & $2.40 \mathrm{E}-12$ & $26 \%$ & $41 \%$ & $7 \%$ & 2.2 \\
\hline 1UX2_I & 63.5 & $2.40 \mathrm{E}-12$ & $26 \%$ & $41 \%$ & $7 \%$ & 2.2 \\
\hline 1UX2_J & 63.5 & $2.40 \mathrm{E}-12$ & $26 \%$ & $41 \%$ & $7 \%$ & 2.2 \\
\hline 2WNC_A & 87.8 & $1.00 \mathrm{E}-20$ & $28 \%$ & $43 \%$ & $2 \%$ & 2.2 \\
\hline 2WNC_B & 87.8 & $1.00 \mathrm{E}-20$ & $28 \%$ & $43 \%$ & $2 \%$ & 2.2 \\
\hline 2WNC_C & 87.8 & $1.00 \mathrm{E}-20$ & $28 \%$ & $43 \%$ & $2 \%$ & 2.2 \\
\hline 2WNC_D & 87.8 & $1.00 \mathrm{E}-20$ & $28 \%$ & $43 \%$ & $2 \%$ & 2.2 \\
\hline 2WNC_E & 87.8 & $1.00 \mathrm{E}-20$ & $28 \%$ & $43 \%$ & $2 \%$ & 2.2 \\
\hline 4B5D_A & 99.8 & $6.30 \mathrm{E}-25$ & $31 \%$ & $48 \%$ & $7 \%$ & 2.2 \\
\hline
\end{tabular}




\section{Continued}

\begin{tabular}{|c|c|c|c|c|c|c|}
\hline 4B5D_B & 99.8 & $6.30 \mathrm{E}-25$ & $31 \%$ & $48 \%$ & $7 \%$ & 2.2 \\
\hline 4B5D_C & 99.8 & $6.30 \mathrm{E}-25$ & $31 \%$ & $48 \%$ & $7 \%$ & 2.2 \\
\hline 4B5D_D & 99.8 & $6.30 \mathrm{E}-25$ & $31 \%$ & $48 \%$ & $7 \%$ & 2.2 \\
\hline 4B5D_E & 99.8 & $6.30 \mathrm{E}-25$ & $31 \%$ & $48 \%$ & $7 \%$ & 2.2 \\
\hline 2C9T_A & 89.4 & $3.00 \mathrm{E}-21$ & $29 \%$ & $43 \%$ & $2 \%$ & 2.25 \\
\hline 2C9T_B & 89.4 & $3.00 \mathrm{E}-21$ & $29 \%$ & $43 \%$ & $2 \%$ & 2.25 \\
\hline 2C9T_C & 89.4 & $3.00 \mathrm{E}-21$ & $29 \%$ & $43 \%$ & $2 \%$ & 2.25 \\
\hline 2C9T_D & 89.4 & $3.00 \mathrm{E}-21$ & $29 \%$ & $43 \%$ & $2 \%$ & 2.25 \\
\hline 2C9T_E & 89.4 & $3.00 \mathrm{E}-21$ & $29 \%$ & $43 \%$ & $2 \%$ & 2.25 \\
\hline 2C9T_F & 89.4 & $3.00 \mathrm{E}-21$ & $29 \%$ & $43 \%$ & $2 \%$ & 2.25 \\
\hline 2C9T_G & 89.4 & $3.00 \mathrm{E}-21$ & $29 \%$ & $43 \%$ & $2 \%$ & 2.25 \\
\hline 2C9T_H & 89.4 & $3.00 \mathrm{E}-21$ & $29 \%$ & $43 \%$ & $2 \%$ & 2.25 \\
\hline 2C9T_I & 89.4 & $3.00 \mathrm{E}-21$ & $29 \%$ & $43 \%$ & $2 \%$ & 2.25 \\
\hline 2C9T_J & 89.4 & $3.00 \mathrm{E}-21$ & $29 \%$ & $43 \%$ & $2 \%$ & 2.25 \\
\hline 3IGQ_A & 31.6 & 0.3 & $25 \%$ & $45 \%$ & $9 \%$ & 2.3 \\
\hline 3IGQ_B & 31.6 & 0.3 & $25 \%$ & $45 \%$ & $9 \%$ & 2.3 \\
\hline 3IGQ_C & 31.6 & 0.3 & $25 \%$ & $45 \%$ & $9 \%$ & 2.3 \\
\hline 3IGQ_D & 31.6 & 0.3 & $25 \%$ & $45 \%$ & $9 \%$ & 2.3 \\
\hline 3IGQ_E & 31.6 & 0.3 & $25 \%$ & $45 \%$ & $9 \%$ & 2.3 \\
\hline 3IGQ_F & 31.6 & 0.3 & $25 \%$ & $45 \%$ & $9 \%$ & 2.3 \\
\hline 4ALX_A & 63.5 & $2.80 \mathrm{E}-12$ & $25 \%$ & $41 \%$ & $7 \%$ & 2.3 \\
\hline 4ALX_B & 63.5 & $2.80 \mathrm{E}-12$ & $25 \%$ & $41 \%$ & $7 \%$ & 2.3 \\
\hline 4ALX_C & 63.5 & $2.80 \mathrm{E}-12$ & $25 \%$ & $41 \%$ & $7 \%$ & 2.3 \\
\hline 4ALX_D & 63.5 & $2.80 \mathrm{E}-12$ & $25 \%$ & $41 \%$ & $7 \%$ & 2.3 \\
\hline 4ALX_E & 63.5 & $2.80 \mathrm{E}-12$ & $25 \%$ & $41 \%$ & $7 \%$ & 2.3 \\
\hline 4ALX_F & 63.5 & $2.80 \mathrm{E}-12$ & $25 \%$ & $41 \%$ & $7 \%$ & 2.3 \\
\hline 4ALX_G & 63.5 & $2.80 \mathrm{E}-12$ & $25 \%$ & $41 \%$ & $7 \%$ & 2.3 \\
\hline 4ALX_H & 63.5 & $2.80 \mathrm{E}-12$ & $25 \%$ & $41 \%$ & $7 \%$ & 2.3 \\
\hline 4ALX_I & 63.5 & $2.80 \mathrm{E}-12$ & $25 \%$ & $41 \%$ & $7 \%$ & 2.3 \\
\hline 4ALX_J & 63.5 & $2.80 \mathrm{E}-12$ & $25 \%$ & $41 \%$ & $7 \%$ & 2.3 \\
\hline 4DBM_A & 87.8 & $1.10 \mathrm{E}-20$ & $28 \%$ & $43 \%$ & $2 \%$ & 2.3 \\
\hline 4DBM_B & 87.8 & $1.10 \mathrm{E}-20$ & $28 \%$ & $43 \%$ & $2 \%$ & 2.3 \\
\hline 4DBM_C & 87.8 & $1.10 \mathrm{E}-20$ & $28 \%$ & $43 \%$ & $2 \%$ & 2.3 \\
\hline 4DBM_D & 87.8 & $1.10 \mathrm{E}-20$ & $28 \%$ & $43 \%$ & $2 \%$ & 2.3 \\
\hline 4DBM_E & 87.8 & $1.10 \mathrm{E}-20$ & $28 \%$ & $43 \%$ & $2 \%$ & 2.3 \\
\hline 3U8L_A & 63.5 & $2.00 \mathrm{E}-12$ & $26 \%$ & $41 \%$ & $7 \%$ & 2.32 \\
\hline 3U8L_B & 63.5 & $2.00 \mathrm{E}-12$ & $26 \%$ & $41 \%$ & $7 \%$ & 2.32 \\
\hline
\end{tabular}




\section{Continued}

\begin{tabular}{|c|c|c|c|c|c|c|}
\hline 3U8L_C & 63.5 & $2.00 \mathrm{E}-12$ & $26 \%$ & $41 \%$ & $7 \%$ & 2.32 \\
\hline 3U8L_D & 63.5 & $2.00 \mathrm{E}-12$ & $26 \%$ & $41 \%$ & $7 \%$ & 2.32 \\
\hline 3U8L_E & 63.5 & $2.00 \mathrm{E}-12$ & $26 \%$ & $41 \%$ & $7 \%$ & 2.32 \\
\hline 3U8L_F & 63.5 & $2.00 \mathrm{E}-12$ & $26 \%$ & $41 \%$ & $7 \%$ & 2.32 \\
\hline 3U8L_G & 63.5 & $2.00 \mathrm{E}-12$ & $26 \%$ & $41 \%$ & $7 \%$ & 2.32 \\
\hline 3U8L_H & 63.5 & $2.00 \mathrm{E}-12$ & $26 \%$ & $41 \%$ & $7 \%$ & 2.32 \\
\hline 3U8L_I & 63.5 & $2.00 \mathrm{E}-12$ & $26 \%$ & $41 \%$ & $7 \%$ & 2.32 \\
\hline 3U8L_J & 63.5 & $2.00 \mathrm{E}-12$ & $26 \%$ & $41 \%$ & $7 \%$ & 2.32 \\
\hline 3SIO_A & 85.9 & $4.80 \mathrm{E}-20$ & $28 \%$ & $42 \%$ & $2 \%$ & 2.32 \\
\hline 3SIO_B & 85.9 & $4.80 \mathrm{E}-20$ & $28 \%$ & $42 \%$ & $2 \%$ & 2.32 \\
\hline 3SIO_C & 85.9 & $4.80 \mathrm{E}-20$ & $28 \%$ & $42 \%$ & $2 \%$ & 2.32 \\
\hline 3SIO_D & 85.9 & $4.80 \mathrm{E}-20$ & $28 \%$ & $42 \%$ & $2 \%$ & 2.32 \\
\hline 3SIO_E & 85.9 & $4.80 \mathrm{E}-20$ & $28 \%$ & $42 \%$ & $2 \%$ & 2.32 \\
\hline 3SIO_F & 85.9 & $4.80 \mathrm{E}-20$ & $28 \%$ & $42 \%$ & $2 \%$ & 2.32 \\
\hline 3SIO_G & 85.9 & $4.80 \mathrm{E}-20$ & $28 \%$ & $42 \%$ & $2 \%$ & 2.32 \\
\hline 3SIO_H & 85.9 & $4.80 \mathrm{E}-20$ & $28 \%$ & $42 \%$ & $2 \%$ & 2.32 \\
\hline 3SIO_I & 85.9 & $4.80 \mathrm{E}-20$ & $28 \%$ & $42 \%$ & $2 \%$ & 2.32 \\
\hline 3SIO_J & 85.9 & $4.80 \mathrm{E}-20$ & $28 \%$ & $42 \%$ & $2 \%$ & 2.32 \\
\hline 3U8J_A & 63.5 & $2.00 \mathrm{E}-12$ & $26 \%$ & $41 \%$ & $7 \%$ & 2.35 \\
\hline 3U8J_B & 63.5 & $2.00 \mathrm{E}-12$ & $26 \%$ & $41 \%$ & $7 \%$ & 2.35 \\
\hline 3U8J_C & 63.5 & $2.00 \mathrm{E}-12$ & $26 \%$ & $41 \%$ & $7 \%$ & 2.35 \\
\hline 3U8J_D & 63.5 & $2.00 \mathrm{E}-12$ & $26 \%$ & $41 \%$ & $7 \%$ & 2.35 \\
\hline 3U8J_E & 63.5 & $2.00 \mathrm{E}-12$ & $26 \%$ & $41 \%$ & $7 \%$ & 2.35 \\
\hline 3U8J_F & 63.5 & $2.00 \mathrm{E}-12$ & $26 \%$ & $41 \%$ & $7 \%$ & 2.35 \\
\hline 3U8J_G & 63.5 & $2.00 \mathrm{E}-12$ & $26 \%$ & $41 \%$ & $7 \%$ & 2.35 \\
\hline 3U8J_H & 63.5 & $2.00 \mathrm{E}-12$ & $26 \%$ & $41 \%$ & $7 \%$ & 2.35 \\
\hline 3U8J_I & 63.5 & $2.00 \mathrm{E}-12$ & $26 \%$ & $41 \%$ & $7 \%$ & 2.35 \\
\hline 3U8J_J & 63.5 & $2.00 \mathrm{E}-12$ & $26 \%$ & $41 \%$ & $7 \%$ & 2.35 \\
\hline 3U8N_A & 63.5 & $2.00 \mathrm{E}-12$ & $26 \%$ & $41 \%$ & $7 \%$ & 2.35 \\
\hline 3U8N_B & 63.5 & $2.00 \mathrm{E}-12$ & $26 \%$ & $41 \%$ & $7 \%$ & 2.35 \\
\hline 3U8N_C & 63.5 & $2.00 \mathrm{E}-12$ & $26 \%$ & $41 \%$ & $7 \%$ & 2.35 \\
\hline 3U8N_D & 63.5 & $2.00 \mathrm{E}-12$ & $26 \%$ & $41 \%$ & $7 \%$ & 2.35 \\
\hline 3U8N_E & 63.5 & $2.00 \mathrm{E}-12$ & $26 \%$ & $41 \%$ & $7 \%$ & 2.35 \\
\hline 3U8N_F & 63.5 & $2.00 \mathrm{E}-12$ & $26 \%$ & $41 \%$ & $7 \%$ & 2.35 \\
\hline 3U8N_G & 63.5 & $2.00 \mathrm{E}-12$ & $26 \%$ & $41 \%$ & $7 \%$ & 2.35 \\
\hline 3U8N_H & 63.5 & $2.00 \mathrm{E}-12$ & $26 \%$ & $41 \%$ & $7 \%$ & 2.35 \\
\hline 3U8N_I & 63.5 & $2.00 \mathrm{E}-12$ & $26 \%$ & $41 \%$ & $7 \%$ & 2.35 \\
\hline
\end{tabular}




\section{Continued}

\begin{tabular}{|c|c|c|c|c|c|c|}
\hline 3U8N_J & 63.5 & $2.00 \mathrm{E}-12$ & $26 \%$ & $41 \%$ & $7 \%$ & 2.35 \\
\hline 3U8N_K & 63.5 & $2.00 \mathrm{E}-12$ & $26 \%$ & $41 \%$ & $7 \%$ & 2.35 \\
\hline 3U8N_L & 63.5 & $2.00 \mathrm{E}-12$ & $26 \%$ & $41 \%$ & $7 \%$ & 2.35 \\
\hline 3U8N_M & 63.5 & $2.00 \mathrm{E}-12$ & $26 \%$ & $41 \%$ & $7 \%$ & 2.35 \\
\hline 3U8N_N & 63.5 & $2.00 \mathrm{E}-12$ & $26 \%$ & $41 \%$ & $7 \%$ & 2.35 \\
\hline 3U8N_O & 63.5 & $2.00 \mathrm{E}-12$ & $26 \%$ & $41 \%$ & $7 \%$ & 2.35 \\
\hline 3U8N_P & 63.5 & $2.00 \mathrm{E}-12$ & $26 \%$ & $41 \%$ & $7 \%$ & 2.35 \\
\hline 3U8N_Q & 63.5 & $2.00 \mathrm{E}-12$ & $26 \%$ & $41 \%$ & $7 \%$ & 2.35 \\
\hline 3U8N_R & 63.5 & $2.00 \mathrm{E}-12$ & $26 \%$ & $41 \%$ & $7 \%$ & 2.35 \\
\hline 3U8N_S & 63.5 & $2.00 \mathrm{E}-12$ & $26 \%$ & $41 \%$ & $7 \%$ & 2.35 \\
\hline 3U8N_T & 63.5 & $2.00 \mathrm{E}-12$ & $26 \%$ & $41 \%$ & $7 \%$ & 2.35 \\
\hline 2X00_A & 87.8 & $1.20 \mathrm{E}-20$ & $28 \%$ & $43 \%$ & $2 \%$ & 2.4 \\
\hline 2X00_B & 87.8 & $1.20 \mathrm{E}-20$ & $28 \%$ & $43 \%$ & $2 \%$ & 2.4 \\
\hline 2X00_C & 87.8 & $1.20 \mathrm{E}-20$ & $28 \%$ & $43 \%$ & $2 \%$ & 2.4 \\
\hline 2X00_D & 87.8 & $9.60 \mathrm{E}-21$ & $28 \%$ & $43 \%$ & $2 \%$ & 2.4 \\
\hline 2X00_E & 87.8 & $1.20 \mathrm{E}-20$ & $28 \%$ & $43 \%$ & $2 \%$ & 2.4 \\
\hline 2BR8_A & 89.4 & $3.00 \mathrm{E}-21$ & $29 \%$ & $43 \%$ & $2 \%$ & 2.4 \\
\hline 2BR8_B & 89.4 & $3.00 \mathrm{E}-21$ & $29 \%$ & $43 \%$ & $2 \%$ & 2.4 \\
\hline 2BR8_C & 89.4 & $3.00 \mathrm{E}-21$ & $29 \%$ & $43 \%$ & $2 \%$ & 2.4 \\
\hline 2BR8_D & 89.4 & $3.00 \mathrm{E}-21$ & $29 \%$ & $43 \%$ & $2 \%$ & 2.4 \\
\hline 2BR8_E & 89.4 & $3.00 \mathrm{E}-21$ & $29 \%$ & $43 \%$ & $2 \%$ & 2.4 \\
\hline 2UZ6_A & 89.4 & $3.00 \mathrm{E}-21$ & $29 \%$ & $43 \%$ & $2 \%$ & 2.4 \\
\hline 2UZ6_B & 89.4 & $3.00 \mathrm{E}-21$ & $29 \%$ & $43 \%$ & $2 \%$ & 2.4 \\
\hline 2UZ6_C & 89.4 & $3.00 \mathrm{E}-21$ & $29 \%$ & $43 \%$ & $2 \%$ & 2.4 \\
\hline 2UZ6_D & 89.4 & $3.00 \mathrm{E}-21$ & $29 \%$ & $43 \%$ & $2 \%$ & 2.4 \\
\hline 2UZ6_E & 89.4 & $3.00 \mathrm{E}-21$ & $29 \%$ & $43 \%$ & $2 \%$ & 2.4 \\
\hline 2UZ6_F & 89.4 & $3.00 \mathrm{E}-21$ & $29 \%$ & $43 \%$ & $2 \%$ & 2.4 \\
\hline 2UZ6_G & 89.4 & $3.00 \mathrm{E}-21$ & $29 \%$ & $43 \%$ & $2 \%$ & 2.4 \\
\hline 2UZ6_H & 89.4 & $3.00 \mathrm{E}-21$ & $29 \%$ & $43 \%$ & $2 \%$ & 2.4 \\
\hline 2UZ6_I & 89.4 & $3.00 \mathrm{E}-21$ & $29 \%$ & $43 \%$ & $2 \%$ & 2.4 \\
\hline 2UZ6_J & 89.4 & $3.00 \mathrm{E}-21$ & $29 \%$ & $43 \%$ & $2 \%$ & 2.4 \\
\hline 2YME_A & 92.4 & $2.00 \mathrm{E}-22$ & $29 \%$ & $43 \%$ & $2 \%$ & 2.4 \\
\hline 2YME_B & 92.4 & $2.00 \mathrm{E}-22$ & $29 \%$ & $43 \%$ & $2 \%$ & 2.4 \\
\hline 2YME_C & 92.4 & $2.00 \mathrm{E}-22$ & $29 \%$ & $43 \%$ & $2 \%$ & 2.4 \\
\hline 2YME_D & 92.4 & $2.00 \mathrm{E}-22$ & $29 \%$ & $43 \%$ & $2 \%$ & 2.4 \\
\hline 2YME_E & 92.4 & $2.00 \mathrm{E}-22$ & $29 \%$ & $43 \%$ & $2 \%$ & 2.4 \\
\hline 2YME_F & 92.4 & $2.00 \mathrm{E}-22$ & $29 \%$ & $43 \%$ & $2 \%$ & 2.4 \\
\hline
\end{tabular}




\section{Continued}

\begin{tabular}{|c|c|c|c|c|c|c|}
\hline 2YME_G & 92.4 & $2.00 \mathrm{E}-22$ & $29 \%$ & $43 \%$ & $2 \%$ & 2.4 \\
\hline 2YME_H & 92.4 & $2.00 \mathrm{E}-22$ & $29 \%$ & $43 \%$ & $2 \%$ & 2.4 \\
\hline 2YME_I & 92.4 & $2.00 \mathrm{E}-22$ & $29 \%$ & $43 \%$ & $2 \%$ & 2.4 \\
\hline 2YME_J & 92.4 & $2.00 \mathrm{E}-22$ & $29 \%$ & $43 \%$ & $2 \%$ & 2.4 \\
\hline 2XNV_A & 90.9 & $9.90 \mathrm{E}-22$ & $27 \%$ & $44 \%$ & $2 \%$ & 2.44 \\
\hline 2XNV_B & 90.9 & $9.90 \mathrm{E}-22$ & $27 \%$ & $44 \%$ & $2 \%$ & 2.44 \\
\hline 2XNV_C & 90.9 & $9.90 \mathrm{E}-22$ & $27 \%$ & $44 \%$ & $2 \%$ & 2.44 \\
\hline 2XNV_D & 90.9 & $9.90 \mathrm{E}-22$ & $27 \%$ & $44 \%$ & $2 \%$ & 2.44 \\
\hline 2XNV_E & 90.9 & $9.90 \mathrm{E}-22$ & $27 \%$ & $44 \%$ & $2 \%$ & 2.44 \\
\hline 2XNV_F & 90.9 & $9.90 \mathrm{E}-22$ & $27 \%$ & $44 \%$ & $2 \%$ & 2.44 \\
\hline 2XNV_G & 90.9 & $9.90 \mathrm{E}-22$ & $27 \%$ & $44 \%$ & $2 \%$ & 2.44 \\
\hline 2XNV_H & 90.9 & $9.90 \mathrm{E}-22$ & $27 \%$ & $44 \%$ & $2 \%$ & 2.44 \\
\hline 2XNV_I & 90.9 & $9.90 \mathrm{E}-22$ & $27 \%$ & $44 \%$ & $2 \%$ & 2.44 \\
\hline $2 \mathrm{XNV} \_\mathrm{J}$ & 90.9 & $9.90 \mathrm{E}-22$ & $27 \%$ & $44 \%$ & $2 \%$ & 2.44 \\
\hline 3PMZ_A & 87.8 & $1.00 \mathrm{E}-20$ & $28 \%$ & $43 \%$ & $2 \%$ & 2.44 \\
\hline 3PMZ_B & 87.8 & $1.00 \mathrm{E}-20$ & $28 \%$ & $43 \%$ & $2 \%$ & 2.44 \\
\hline 3PMZ_C & 87.8 & $1.00 \mathrm{E}-20$ & $28 \%$ & $43 \%$ & $2 \%$ & 2.44 \\
\hline 3PMZ_D & 87.8 & $1.00 \mathrm{E}-20$ & $28 \%$ & $43 \%$ & $2 \%$ & 2.44 \\
\hline 3PMZ_E & 87.8 & $1.00 \mathrm{E}-20$ & $28 \%$ & $43 \%$ & $2 \%$ & 2.44 \\
\hline 3PMZ_F & 87.8 & $1.00 \mathrm{E}-20$ & $28 \%$ & $43 \%$ & $2 \%$ & 2.44 \\
\hline 3PMZ_G & 87.8 & $1.00 \mathrm{E}-20$ & $28 \%$ & $43 \%$ & $2 \%$ & 2.44 \\
\hline 3PMZ_H & 87.8 & $1.00 \mathrm{E}-20$ & $28 \%$ & $43 \%$ & $2 \%$ & 2.44 \\
\hline 3PMZ_I & 87.8 & $1.00 \mathrm{E}-20$ & $28 \%$ & $43 \%$ & $2 \%$ & 2.44 \\
\hline 3PMZ_J & 87.8 & $1.00 \mathrm{E}-20$ & $28 \%$ & $43 \%$ & $2 \%$ & 2.44 \\
\hline 2BYR_A & 87.8 & $1.00 \mathrm{E}-20$ & $28 \%$ & $43 \%$ & $2 \%$ & 2.45 \\
\hline 2BYR_B & 87.8 & $1.00 \mathrm{E}-20$ & $28 \%$ & $43 \%$ & $2 \%$ & 2.45 \\
\hline 2BYR_C & 87.8 & $1.00 \mathrm{E}-20$ & $28 \%$ & $43 \%$ & $2 \%$ & 2.45 \\
\hline 2BYR_D & 87.8 & $1.00 \mathrm{E}-20$ & $28 \%$ & $43 \%$ & $2 \%$ & 2.45 \\
\hline 2BYR_E & 87.8 & $1.00 \mathrm{E}-20$ & $28 \%$ & $43 \%$ & $2 \%$ & 2.45 \\
\hline 2BYR_F & 87.8 & $1.00 \mathrm{E}-20$ & $28 \%$ & $43 \%$ & $2 \%$ & 2.45 \\
\hline 2BYR_G & 87.8 & $1.00 \mathrm{E}-20$ & $28 \%$ & $43 \%$ & $2 \%$ & 2.45 \\
\hline 2BYR_H & 87.8 & $1.00 \mathrm{E}-20$ & $28 \%$ & $43 \%$ & $2 \%$ & 2.45 \\
\hline 2BYR_I & 87.8 & $1.00 \mathrm{E}-20$ & $28 \%$ & $43 \%$ & $2 \%$ & 2.45 \\
\hline 2BYR_J & 87.8 & $1.00 \mathrm{E}-20$ & $28 \%$ & $43 \%$ & $2 \%$ & 2.45 \\
\hline 3U8K_A & 63.5 & $2.00 \mathrm{E}-12$ & $26 \%$ & $41 \%$ & $7 \%$ & 2.47 \\
\hline 3U8K_B & 63.5 & $2.00 \mathrm{E}-12$ & $26 \%$ & $41 \%$ & $7 \%$ & 2.47 \\
\hline 3U8K_C & 63.5 & $2.00 \mathrm{E}-12$ & $26 \%$ & $41 \%$ & $7 \%$ & 2.47 \\
\hline
\end{tabular}




\section{Continued}

\begin{tabular}{|c|c|c|c|c|c|c|}
\hline 3U8K_D & 63.5 & $2.00 \mathrm{E}-12$ & $26 \%$ & $41 \%$ & $7 \%$ & 2.47 \\
\hline 3U8K_E & 63.5 & $2.00 \mathrm{E}-12$ & $26 \%$ & $41 \%$ & $7 \%$ & 2.47 \\
\hline 3U8K_F & 63.5 & $2.00 \mathrm{E}-12$ & $26 \%$ & $41 \%$ & $7 \%$ & 2.47 \\
\hline 3U8K_G & 63.5 & $2.00 \mathrm{E}-12$ & $26 \%$ & $41 \%$ & $7 \%$ & 2.47 \\
\hline 3U8K_H & 63.5 & $2.00 \mathrm{E}-12$ & $26 \%$ & $41 \%$ & $7 \%$ & 2.47 \\
\hline 3U8K_I & 63.5 & $2.00 \mathrm{E}-12$ & $26 \%$ & $41 \%$ & $7 \%$ & 2.47 \\
\hline 3U8K_J & 63.5 & $2.00 \mathrm{E}-12$ & $26 \%$ & $41 \%$ & $7 \%$ & 2.47 \\
\hline 3U8K_K & 63.5 & $2.00 \mathrm{E}-12$ & $26 \%$ & $41 \%$ & $7 \%$ & 2.47 \\
\hline 3U8K_L & 63.5 & $2.00 \mathrm{E}-12$ & $26 \%$ & $41 \%$ & $7 \%$ & 2.47 \\
\hline 3U8K_M & 63.5 & $2.00 \mathrm{E}-12$ & $26 \%$ & $41 \%$ & $7 \%$ & 2.47 \\
\hline 3U8K_N & 63.5 & $2.00 \mathrm{E}-12$ & $26 \%$ & $41 \%$ & $7 \%$ & 2.47 \\
\hline 3U8K_O & 63.5 & $2.00 \mathrm{E}-12$ & $26 \%$ & $41 \%$ & $7 \%$ & 2.47 \\
\hline 3U8K_P & 63.5 & $2.00 \mathrm{E}-12$ & $26 \%$ & $41 \%$ & $7 \%$ & 2.47 \\
\hline 3U8K_Q & 63.5 & $2.00 \mathrm{E}-12$ & $26 \%$ & $41 \%$ & $7 \%$ & 2.47 \\
\hline 3U8K_R & 63.5 & $2.00 \mathrm{E}-12$ & $26 \%$ & $41 \%$ & $7 \%$ & 2.47 \\
\hline 3U8K_S & 63.5 & $2.00 \mathrm{E}-12$ & $26 \%$ & $41 \%$ & $7 \%$ & 2.47 \\
\hline 3U8K_T & 63.5 & $2.00 \mathrm{E}-12$ & $26 \%$ & $41 \%$ & $7 \%$ & 2.47 \\
\hline 3C79_A & 87.8 & $1.00 \mathrm{E}-20$ & $28 \%$ & $43 \%$ & $2 \%$ & 2.48 \\
\hline 3C79_B & 87.8 & $1.00 \mathrm{E}-20$ & $28 \%$ & $43 \%$ & $2 \%$ & 2.48 \\
\hline 3C79_C & 87.8 & $1.00 \mathrm{E}-20$ & $28 \%$ & $43 \%$ & $2 \%$ & 2.48 \\
\hline 3C79_D & 87.8 & $1.00 \mathrm{E}-20$ & $28 \%$ & $43 \%$ & $2 \%$ & 2.48 \\
\hline 3C79_E & 87.8 & $1.00 \mathrm{E}-20$ & $28 \%$ & $43 \%$ & $2 \%$ & 2.48 \\
\hline 1UV6_A & 63.5 & $2.00 \mathrm{E}-12$ & $26 \%$ & $41 \%$ & $7 \%$ & 2.5 \\
\hline 1UV6_B & 63.5 & $2.00 \mathrm{E}-12$ & $26 \%$ & $41 \%$ & $7 \%$ & 2.5 \\
\hline 1UV6_C & 63.5 & $2.00 \mathrm{E}-12$ & $26 \%$ & $41 \%$ & $7 \%$ & 2.5 \\
\hline 1UV6_D & 63.5 & $2.00 \mathrm{E}-12$ & $26 \%$ & $41 \%$ & $7 \%$ & 2.5 \\
\hline 1UV6_E & 63.5 & $2.00 \mathrm{E}-12$ & $26 \%$ & $41 \%$ & $7 \%$ & 2.5 \\
\hline 1UV6_F & 63.5 & $2.00 \mathrm{E}-12$ & $26 \%$ & $41 \%$ & $7 \%$ & 2.5 \\
\hline 1UV6_G & 63.5 & $2.00 \mathrm{E}-12$ & $26 \%$ & $41 \%$ & $7 \%$ & 2.5 \\
\hline 1UV6_H & 63.5 & $2.00 \mathrm{E}-12$ & $26 \%$ & $41 \%$ & $7 \%$ & 2.5 \\
\hline 1UV6_I & 63.5 & $2.00 \mathrm{E}-12$ & $26 \%$ & $41 \%$ & $7 \%$ & 2.5 \\
\hline 1UV6_J & 63.5 & $2.00 \mathrm{E}-12$ & $26 \%$ & $41 \%$ & $7 \%$ & 2.5 \\
\hline 3C75_L & 27.7 & 5.3 & $27 \%$ & $41 \%$ & $11 \%$ & 2.5 \\
\hline 3C75_M & 27.7 & 5.3 & $27 \%$ & $41 \%$ & $11 \%$ & 2.5 \\
\hline 2WZY_A & 87.8 & $1.20 \mathrm{E}-20$ & $28 \%$ & $43 \%$ & $2 \%$ & 2.51 \\
\hline 2WZY_B & 87.8 & $1.20 \mathrm{E}-20$ & $28 \%$ & $43 \%$ & $2 \%$ & 2.51 \\
\hline 2WZY_C & 87.8 & $1.20 \mathrm{E}-20$ & $28 \%$ & $43 \%$ & $2 \%$ & 2.51 \\
\hline
\end{tabular}




\section{Continued}

\begin{tabular}{|c|c|c|c|c|c|c|}
\hline 2WZY_D & 87.8 & $1.20 \mathrm{E}-20$ & $28 \%$ & $43 \%$ & $2 \%$ & 2.51 \\
\hline 2WZY_E & 87.8 & $1.20 \mathrm{E}-20$ & $28 \%$ & $43 \%$ & $2 \%$ & 2.51 \\
\hline 2WZY_F & 87.8 & $1.20 \mathrm{E}-20$ & $28 \%$ & $43 \%$ & $2 \%$ & 2.51 \\
\hline 2WZY_G & 87.8 & $1.20 \mathrm{E}-20$ & $28 \%$ & $43 \%$ & $2 \%$ & 2.51 \\
\hline 2WZY_H & 87.8 & $1.20 \mathrm{E}-20$ & $28 \%$ & $43 \%$ & $2 \%$ & 2.51 \\
\hline 2WZY_I & 87.8 & $1.20 \mathrm{E}-20$ & $28 \%$ & $43 \%$ & $2 \%$ & 2.51 \\
\hline 2WZY_J & 87.8 & $1.20 \mathrm{E}-20$ & $28 \%$ & $43 \%$ & $2 \%$ & 2.51 \\
\hline 2XNU_A & 90.9 & $9.90 \mathrm{E}-22$ & $27 \%$ & $44 \%$ & $2 \%$ & 2.55 \\
\hline 2XNU_B & 90.9 & $9.90 \mathrm{E}-22$ & $27 \%$ & $44 \%$ & $2 \%$ & 2.55 \\
\hline 2XNU_C & 90.9 & $9.90 \mathrm{E}-22$ & $27 \%$ & $44 \%$ & $2 \%$ & 2.55 \\
\hline 2XNU_D & 90.9 & $9.90 \mathrm{E}-22$ & $27 \%$ & $44 \%$ & $2 \%$ & 2.55 \\
\hline 2XNU_E & 90.9 & $9.90 \mathrm{E}-22$ & $27 \%$ & $44 \%$ & $2 \%$ & 2.55 \\
\hline 2ZJU_A & 65.5 & $5.50 \mathrm{E}-13$ & $26 \%$ & $41 \%$ & $7 \%$ & 2.58 \\
\hline 2ZJU_B & 65.5 & $5.50 \mathrm{E}-13$ & $26 \%$ & $41 \%$ & $7 \%$ & 2.58 \\
\hline 2ZJU_C & 65.5 & $5.50 \mathrm{E}-13$ & $26 \%$ & $41 \%$ & $7 \%$ & 2.58 \\
\hline 2ZJU_D & 65.5 & $5.50 \mathrm{E}-13$ & $26 \%$ & $41 \%$ & $7 \%$ & 2.58 \\
\hline 2ZJU_E & 65.5 & $5.50 \mathrm{E}-13$ & $26 \%$ & $41 \%$ & $7 \%$ & 2.58 \\
\hline 3TLW_A & 33.1 & 0.12 & $24 \%$ & $43 \%$ & $13 \%$ & 2.6 \\
\hline 3TLW_B & 33.1 & 0.12 & $24 \%$ & $43 \%$ & $13 \%$ & 2.6 \\
\hline 3TLW_C & 33.1 & 0.12 & $24 \%$ & $43 \%$ & $13 \%$ & 2.6 \\
\hline 3TLW_D & 33.1 & 0.12 & $24 \%$ & $43 \%$ & $13 \%$ & 2.6 \\
\hline 3TLW_E & 33.1 & 0.12 & $24 \%$ & $43 \%$ & $13 \%$ & 2.6 \\
\hline 2W8G_A & 89.4 & $3.00 \mathrm{E}-21$ & $29 \%$ & $43 \%$ & $2 \%$ & 2.6 \\
\hline 2W8G_B & 89.4 & $3.00 \mathrm{E}-21$ & $29 \%$ & $43 \%$ & $2 \%$ & 2.6 \\
\hline 2W8G_C & 89.4 & $3.00 \mathrm{E}-21$ & $29 \%$ & $43 \%$ & $2 \%$ & 2.6 \\
\hline 2W8G_D & 89.4 & $3.00 \mathrm{E}-21$ & $29 \%$ & $43 \%$ & $2 \%$ & 2.6 \\
\hline 2W8G_E & 89.4 & $3.00 \mathrm{E}-21$ & $29 \%$ & $43 \%$ & $2 \%$ & 2.6 \\
\hline 1I9B_A & 63.5 & $2.30 \mathrm{E}-12$ & $26 \%$ & $41 \%$ & $7 \%$ & 2.7 \\
\hline 1I9B_B & 63.5 & $2.30 \mathrm{E}-12$ & $26 \%$ & $41 \%$ & $7 \%$ & 2.7 \\
\hline 1I9B_C & 63.5 & $2.30 \mathrm{E}-12$ & $26 \%$ & $41 \%$ & $7 \%$ & 2.7 \\
\hline 1I9B_D & 63.5 & $2.30 \mathrm{E}-12$ & $26 \%$ & $41 \%$ & $7 \%$ & 2.7 \\
\hline 1I9B_E & 63.5 & $2.30 \mathrm{E}-12$ & $26 \%$ & $41 \%$ & $7 \%$ & 2.7 \\
\hline 2ZJV_A & 65.5 & $5.50 \mathrm{E}-13$ & $26 \%$ & $41 \%$ & $7 \%$ & 2.7 \\
\hline 2ZJV_B & 65.5 & $5.50 \mathrm{E}-13$ & $26 \%$ & $41 \%$ & $7 \%$ & 2.7 \\
\hline 2ZJV_C & 65.5 & $5.50 \mathrm{E}-13$ & $26 \%$ & $41 \%$ & $7 \%$ & 2.7 \\
\hline 2ZJV_D & 65.5 & $5.50 \mathrm{E}-13$ & $26 \%$ & $41 \%$ & $7 \%$ & 2.7 \\
\hline 2ZJV_E & 65.5 & $5.50 \mathrm{E}-13$ & $26 \%$ & $41 \%$ & $7 \%$ & 2.7 \\
\hline
\end{tabular}




\section{Continued}

\begin{tabular}{|c|c|c|c|c|c|c|}
\hline 3U8M_A & 63.5 & $2.00 \mathrm{E}-12$ & $26 \%$ & $41 \%$ & $7 \%$ & 2.7 \\
\hline 3U8M_B & 63.5 & $2.00 \mathrm{E}-12$ & $26 \%$ & $41 \%$ & $7 \%$ & 2.7 \\
\hline 3U8M_C & 63.5 & $2.00 \mathrm{E}-12$ & $26 \%$ & $41 \%$ & $7 \%$ & 2.7 \\
\hline 3U8M_D & 63.5 & $2.00 \mathrm{E}-12$ & $26 \%$ & $41 \%$ & $7 \%$ & 2.7 \\
\hline 3U8M_E & 63.5 & $2.00 \mathrm{E}-12$ & $26 \%$ & $41 \%$ & $7 \%$ & 2.7 \\
\hline 3U8M_F & 63.5 & $2.00 \mathrm{E}-12$ & $26 \%$ & $41 \%$ & $7 \%$ & 2.7 \\
\hline 3U8M_G & 63.5 & $2.00 \mathrm{E}-12$ & $26 \%$ & $41 \%$ & $7 \%$ & 2.7 \\
\hline 3U8M_H & 63.5 & $2.00 \mathrm{E}-12$ & $26 \%$ & $41 \%$ & $7 \%$ & 2.7 \\
\hline 3U8M_I & 63.5 & $2.00 \mathrm{E}-12$ & $26 \%$ & $41 \%$ & $7 \%$ & 2.7 \\
\hline 3U8M_J & 63.5 & $2.00 \mathrm{E}-12$ & $26 \%$ & $41 \%$ & $7 \%$ & 2.7 \\
\hline 3U8M_K & 63.5 & $2.00 \mathrm{E}-12$ & $26 \%$ & $41 \%$ & $7 \%$ & 2.7 \\
\hline 3U8M_L & 63.5 & $2.00 \mathrm{E}-12$ & $26 \%$ & $41 \%$ & $7 \%$ & 2.7 \\
\hline 3U8M_M & 63.5 & $2.00 \mathrm{E}-12$ & $26 \%$ & $41 \%$ & $7 \%$ & 2.7 \\
\hline 3U8M_N & 63.5 & $2.00 \mathrm{E}-12$ & $26 \%$ & $41 \%$ & $7 \%$ & 2.7 \\
\hline 3U8M_O & 63.5 & $2.00 \mathrm{E}-12$ & $26 \%$ & $41 \%$ & $7 \%$ & 2.7 \\
\hline 3U8M_P & 63.5 & $2.00 \mathrm{E}-12$ & $26 \%$ & $41 \%$ & $7 \%$ & 2.7 \\
\hline 3U8M_Q & 63.5 & $2.00 \mathrm{E}-12$ & $26 \%$ & $41 \%$ & $7 \%$ & 2.7 \\
\hline 3U8M_R & 63.5 & $2.00 \mathrm{E}-12$ & $26 \%$ & $41 \%$ & $7 \%$ & 2.7 \\
\hline 3U8M_S & 63.5 & $2.00 \mathrm{E}-12$ & $26 \%$ & $41 \%$ & $7 \%$ & 2.7 \\
\hline 3U8M_T & 63.5 & $2.00 \mathrm{E}-12$ & $26 \%$ & $41 \%$ & $7 \%$ & 2.7 \\
\hline 2WNL_A & 87.8 & $1.00 \mathrm{E}-20$ & $28 \%$ & $43 \%$ & $2 \%$ & 2.7 \\
\hline 2WNL_B & 87.8 & $1.00 \mathrm{E}-20$ & $28 \%$ & $43 \%$ & $2 \%$ & 2.7 \\
\hline 2WNL_C & 87.8 & $1.00 \mathrm{E}-20$ & $28 \%$ & $43 \%$ & $2 \%$ & 2.7 \\
\hline 2WNL_D & 87.8 & $1.00 \mathrm{E}-20$ & $28 \%$ & $43 \%$ & $2 \%$ & 2.7 \\
\hline 2WNL_E & 87.8 & $1.00 \mathrm{E}-20$ & $28 \%$ & $43 \%$ & $2 \%$ & 2.7 \\
\hline 2WNL_F & 87.8 & $1.00 \mathrm{E}-20$ & $28 \%$ & $43 \%$ & $2 \%$ & 2.7 \\
\hline 2WNL_G & 87.8 & $1.00 \mathrm{E}-20$ & $28 \%$ & $43 \%$ & $2 \%$ & 2.7 \\
\hline 2WNL_H & 87.8 & $1.00 \mathrm{E}-20$ & $28 \%$ & $43 \%$ & $2 \%$ & 2.7 \\
\hline 2WNL_I & 87.8 & $1.00 \mathrm{E}-20$ & $28 \%$ & $43 \%$ & $2 \%$ & 2.7 \\
\hline 2WNL_J & 87.8 & $1.00 \mathrm{E}-20$ & $28 \%$ & $43 \%$ & $2 \%$ & 2.7 \\
\hline 2W8F_A & 89.4 & $3.00 \mathrm{E}-21$ & $29 \%$ & $43 \%$ & $2 \%$ & 2.7 \\
\hline 2W8F_B & 89.4 & $3.00 \mathrm{E}-21$ & $29 \%$ & $43 \%$ & $2 \%$ & 2.7 \\
\hline 2W8F_C & 89.4 & $3.00 \mathrm{E}-21$ & $29 \%$ & $43 \%$ & $2 \%$ & 2.7 \\
\hline 2W8F_D & 89.4 & $3.00 \mathrm{E}-21$ & $29 \%$ & $43 \%$ & $2 \%$ & 2.7 \\
\hline 2W8F_E & 89.4 & $3.00 \mathrm{E}-21$ & $29 \%$ & $43 \%$ & $2 \%$ & 2.7 \\
\hline 2W8F_F & 89.4 & $3.00 \mathrm{E}-21$ & $29 \%$ & $43 \%$ & $2 \%$ & 2.7 \\
\hline 2W8F_G & 89.4 & $3.00 \mathrm{E}-21$ & $29 \%$ & $43 \%$ & $2 \%$ & 2.7 \\
\hline
\end{tabular}




\section{Continued}

\begin{tabular}{|c|c|c|c|c|c|c|}
\hline 2W8F_H & 89.4 & $3.00 \mathrm{E}-21$ & $29 \%$ & $43 \%$ & $2 \%$ & 2.7 \\
\hline 2W8F_I & 89.4 & $3.00 \mathrm{E}-21$ & $29 \%$ & $43 \%$ & $2 \%$ & 2.7 \\
\hline 2W8F_J & 89.4 & $3.00 \mathrm{E}-21$ & $29 \%$ & $43 \%$ & $2 \%$ & 2.7 \\
\hline 2XZ5_A & 87.8 & $1.10 \mathrm{E}-20$ & $29 \%$ & $43 \%$ & $2 \%$ & 2.8 \\
\hline 2XZ5_B & 87.8 & $1.10 \mathrm{E}-20$ & $29 \%$ & $43 \%$ & $2 \%$ & 2.8 \\
\hline 2XZ5_C & 87.8 & $1.10 \mathrm{E}-20$ & $29 \%$ & $43 \%$ & $2 \%$ & 2.8 \\
\hline 2XZ5_D & 87.8 & $1.10 \mathrm{E}-20$ & $29 \%$ & $43 \%$ & $2 \%$ & 2.8 \\
\hline 2XZ5_E & 87.8 & $1.10 \mathrm{E}-20$ & $29 \%$ & $43 \%$ & $2 \%$ & 2.8 \\
\hline 3SQ6_A & 104.4 & $6.40 \mathrm{E}-27$ & $31 \%$ & $48 \%$ & $3 \%$ & 2.8 \\
\hline 3SQ6_B & 104.4 & $6.40 \mathrm{E}-27$ & $31 \%$ & $48 \%$ & $3 \%$ & 2.8 \\
\hline 3SQ6_C & 104.4 & $6.40 \mathrm{E}-27$ & $31 \%$ & $48 \%$ & $3 \%$ & 2.8 \\
\hline 3SQ6_D & 104.4 & $6.40 \mathrm{E}-27$ & $31 \%$ & $48 \%$ & $3 \%$ & 2.8 \\
\hline 3SQ6_E & 104.4 & $6.40 \mathrm{E}-27$ & $31 \%$ & $48 \%$ & $3 \%$ & 2.8 \\
\hline 3SQ6_F & 104.4 & $6.40 \mathrm{E}-27$ & $31 \%$ & $48 \%$ & $3 \%$ & 2.8 \\
\hline 3SQ6_G & 104.4 & $6.40 \mathrm{E}-27$ & $31 \%$ & $48 \%$ & $3 \%$ & 2.8 \\
\hline 3SQ6_H & 104.4 & $6.40 \mathrm{E}-27$ & $31 \%$ & $48 \%$ & $3 \%$ & 2.8 \\
\hline 3SQ6_I & 104.4 & $6.40 \mathrm{E}-27$ & $31 \%$ & $48 \%$ & $3 \%$ & 2.8 \\
\hline 3SQ6_J & 104.4 & $6.40 \mathrm{E}-27$ & $31 \%$ & $48 \%$ & $3 \%$ & 2.8 \\
\hline 1IQP_A & 30.4 & 1.1 & $38 \%$ & $48 \%$ & $0 \%$ & 2.8 \\
\hline 1IQP_B & 30.4 & 1.1 & $38 \%$ & $48 \%$ & $0 \%$ & 2.8 \\
\hline 1IQP_C & 30.4 & 1.1 & $38 \%$ & $48 \%$ & $0 \%$ & 2.8 \\
\hline 1IQP_D & 30.4 & 1.1 & $38 \%$ & $48 \%$ & $0 \%$ & 2.8 \\
\hline 1IQP_E & 30.4 & 1.1 & $38 \%$ & $48 \%$ & $0 \%$ & 2.8 \\
\hline 1IQP_F & 30.4 & 1.1 & $38 \%$ & $48 \%$ & $0 \%$ & 2.8 \\
\hline 3TLU_A & 33.1 & 0.12 & $24 \%$ & $43 \%$ & $13 \%$ & 2.85 \\
\hline 3TLU_B & 33.1 & 0.12 & $24 \%$ & $43 \%$ & $13 \%$ & 2.85 \\
\hline 3TLU_C & 33.1 & 0.12 & $24 \%$ & $43 \%$ & $13 \%$ & 2.85 \\
\hline 3TLU_D & 33.1 & 0.12 & $24 \%$ & $43 \%$ & $13 \%$ & 2.85 \\
\hline 3TLU_E & 33.1 & 0.12 & $24 \%$ & $43 \%$ & $13 \%$ & 2.85 \\
\hline 2PH9_A & 87.8 & $1.10 \mathrm{E}-20$ & $28 \%$ & $43 \%$ & $2 \%$ & 2.88 \\
\hline 2PH9_B & 87.8 & $1.10 \mathrm{E}-20$ & $28 \%$ & $43 \%$ & $2 \%$ & 2.88 \\
\hline 2PH9_C & 87.8 & $1.10 \mathrm{E}-20$ & $28 \%$ & $43 \%$ & $2 \%$ & 2.88 \\
\hline 2PH9_D & 87.8 & $1.10 \mathrm{E}-20$ & $28 \%$ & $43 \%$ & $2 \%$ & 2.88 \\
\hline 2PH9_E & 87.8 & $1.10 \mathrm{E}-20$ & $28 \%$ & $43 \%$ & $2 \%$ & 2.88 \\
\hline 3TLV_A & 33.5 & 0.11 & $24 \%$ & $43 \%$ & $13 \%$ & 2.9 \\
\hline 3TLV_B & 33.5 & 0.11 & $24 \%$ & $43 \%$ & $13 \%$ & 2.9 \\
\hline 3TLV_C & 33.5 & 0.11 & $24 \%$ & $43 \%$ & $13 \%$ & 2.9 \\
\hline
\end{tabular}




\section{Continued}

\begin{tabular}{|c|c|c|c|c|c|c|}
\hline 3TLV_D & 33.5 & 0.11 & $24 \%$ & $43 \%$ & $13 \%$ & 2.9 \\
\hline 3TLV_E & 33.5 & 0.11 & $24 \%$ & $43 \%$ & $13 \%$ & 2.9 \\
\hline 3UU5_A & 33.5 & 0.12 & $24 \%$ & $43 \%$ & $13 \%$ & 2.9 \\
\hline 3UU5_B & 33.5 & 0.12 & $24 \%$ & $43 \%$ & $13 \%$ & 2.9 \\
\hline 3UU5_C & 33.5 & 0.12 & $24 \%$ & $43 \%$ & $13 \%$ & 2.9 \\
\hline 3UU5_D & 33.5 & 0.12 & $24 \%$ & $43 \%$ & $13 \%$ & 2.9 \\
\hline 3UU5_E & 33.5 & 0.12 & $24 \%$ & $43 \%$ & $13 \%$ & 2.9 \\
\hline 3UUB_A & 33.1 & 0.12 & $24 \%$ & $43 \%$ & $13 \%$ & 2.9 \\
\hline 3UUB_B & 33.1 & 0.12 & $24 \%$ & $43 \%$ & $13 \%$ & 2.9 \\
\hline 3UUB_C & 33.1 & 0.12 & $24 \%$ & $43 \%$ & $13 \%$ & 2.9 \\
\hline 3UUB_D & 33.1 & 0.12 & $24 \%$ & $43 \%$ & $13 \%$ & 2.9 \\
\hline 3UUB_E & 33.1 & 0.12 & $24 \%$ & $43 \%$ & $13 \%$ & 2.9 \\
\hline 3UUB_F & 33.1 & 0.12 & $24 \%$ & $43 \%$ & $13 \%$ & 2.9 \\
\hline 3UUB_G & 33.1 & 0.12 & $24 \%$ & $43 \%$ & $13 \%$ & 2.9 \\
\hline 3UUB_H & 33.1 & 0.12 & $24 \%$ & $43 \%$ & $13 \%$ & 2.9 \\
\hline 3UUB_I & 33.1 & 0.12 & $24 \%$ & $43 \%$ & $13 \%$ & 2.9 \\
\hline 3UUB_J & 33.1 & 0.12 & $24 \%$ & $43 \%$ & $13 \%$ & 2.9 \\
\hline 3EAM_A & 36.6 & 0.0088 & $25 \%$ & $44 \%$ & $13 \%$ & 2.9 \\
\hline 3EAM_B & 36.6 & 0.0088 & $25 \%$ & $44 \%$ & $13 \%$ & 2.9 \\
\hline 3EAM_C & 36.6 & 0.0088 & $25 \%$ & $44 \%$ & $13 \%$ & 2.9 \\
\hline 3EAM_D & 36.6 & 0.0088 & $25 \%$ & $44 \%$ & $13 \%$ & 2.9 \\
\hline 3EAM_E & 36.6 & 0.0088 & $25 \%$ & $44 \%$ & $13 \%$ & 2.9 \\
\hline 3SH1_A & 93.2 & $1.40 \mathrm{E}-22$ & $30 \%$ & $44 \%$ & $2 \%$ & 2.9 \\
\hline 3SH1_B & 93.2 & $1.40 \mathrm{E}-22$ & $30 \%$ & $44 \%$ & $2 \%$ & 2.9 \\
\hline 3SH1_C & 93.2 & $1.40 \mathrm{E}-22$ & $30 \%$ & $44 \%$ & $2 \%$ & 2.9 \\
\hline 3SH1_D & 93.2 & $1.40 \mathrm{E}-22$ & $30 \%$ & $44 \%$ & $2 \%$ & 2.9 \\
\hline 3SH1_E & 93.2 & $1.40 \mathrm{E}-22$ & $30 \%$ & $44 \%$ & $2 \%$ & 2.9 \\
\hline 3SH1_F & 93.2 & $1.40 \mathrm{E}-22$ & $30 \%$ & $44 \%$ & $2 \%$ & 2.9 \\
\hline 3SH1_G & 93.2 & $1.40 \mathrm{E}-22$ & $30 \%$ & $44 \%$ & $2 \%$ & 2.9 \\
\hline 3SH1_H & 93.2 & $1.40 \mathrm{E}-22$ & $30 \%$ & $44 \%$ & $2 \%$ & 2.9 \\
\hline 3SH1_I & 93.2 & $1.40 \mathrm{E}-22$ & $30 \%$ & $44 \%$ & $2 \%$ & 2.9 \\
\hline 3SH1_J & 93.2 & $1.40 \mathrm{E}-22$ & $30 \%$ & $44 \%$ & $2 \%$ & 2.9 \\
\hline 3RQW_A & 42.4 & 0.00013 & $22 \%$ & $41 \%$ & $5 \%$ & 2.91 \\
\hline 3RQW_B & 42.4 & 0.00013 & $22 \%$ & $41 \%$ & $5 \%$ & 2.91 \\
\hline 3RQW_C & 42.4 & 0.00013 & $22 \%$ & $41 \%$ & $5 \%$ & 2.91 \\
\hline 3RQW_D & 42.4 & 0.00013 & $22 \%$ & $41 \%$ & $5 \%$ & 2.91 \\
\hline 3RQW_E & 42.4 & 0.00013 & $22 \%$ & $41 \%$ & $5 \%$ & 2.91 \\
\hline
\end{tabular}




\section{Continued}

\begin{tabular}{|c|c|c|c|c|c|c|}
\hline 3RQW_F & 42.4 & 0.00013 & $22 \%$ & $41 \%$ & $5 \%$ & 2.91 \\
\hline 3RQW_G & 42.4 & 0.00013 & $22 \%$ & $41 \%$ & $5 \%$ & 2.91 \\
\hline 3RQW_H & 42.4 & 0.00013 & $22 \%$ & $41 \%$ & $5 \%$ & 2.91 \\
\hline 3RQW_I & 42.4 & 0.00013 & $22 \%$ & $41 \%$ & $5 \%$ & 2.91 \\
\hline 3RQW_J & 42.4 & 0.00013 & $22 \%$ & $41 \%$ & $5 \%$ & 2.91 \\
\hline 3UU6_A & 33.5 & 0.11 & $24 \%$ & $43 \%$ & $13 \%$ & 2.98 \\
\hline 3UU6_B & 33.5 & 0.11 & $24 \%$ & $43 \%$ & $13 \%$ & 2.98 \\
\hline 3UU6_C & 33.5 & 0.11 & $24 \%$ & $43 \%$ & $13 \%$ & 2.98 \\
\hline 3UU6_D & 33.5 & 0.11 & $24 \%$ & $43 \%$ & $13 \%$ & 2.98 \\
\hline 3UU6_E & 33.5 & 0.11 & $24 \%$ & $43 \%$ & $13 \%$ & 2.98 \\
\hline 4F8H_A & 37.7 & 0.0046 & $24 \%$ & $42 \%$ & $11 \%$ & 2.99 \\
\hline 4F8H_B & 37.7 & 0.0046 & $24 \%$ & $42 \%$ & $11 \%$ & 2.99 \\
\hline 4F8H_C & 37.7 & 0.0046 & $24 \%$ & $42 \%$ & $11 \%$ & 2.99 \\
\hline 4F8H_D & 37.7 & 0.0046 & $24 \%$ & $42 \%$ & $11 \%$ & 2.99 \\
\hline 4F8H_E & 37.7 & 0.0046 & $24 \%$ & $42 \%$ & $11 \%$ & 2.99 \\
\hline 2BR7_A & 89.4 & $3.00 \mathrm{E}-21$ & $29 \%$ & $43 \%$ & $2 \%$ & 3 \\
\hline 2BR7_B & 89.4 & $3.00 \mathrm{E}-21$ & $29 \%$ & $43 \%$ & $2 \%$ & 3 \\
\hline 2BR7_C & 89.4 & $3.00 \mathrm{E}-21$ & $29 \%$ & $43 \%$ & $2 \%$ & 3 \\
\hline 2BR7_D & 89.4 & $3.00 \mathrm{E}-21$ & $29 \%$ & $43 \%$ & $2 \%$ & 3 \\
\hline 2BR7_E & 89.4 & $3.00 \mathrm{E}-21$ & $29 \%$ & $43 \%$ & $2 \%$ & 3 \\
\hline 3T4M_A & 102.1 & $8.20 \mathrm{E}-26$ & $31 \%$ & $45 \%$ & $2 \%$ & 3 \\
\hline 3T4M_B & 102.1 & $8.20 \mathrm{E}-26$ & $31 \%$ & $45 \%$ & $2 \%$ & 3 \\
\hline 3T4M_C & 102.1 & $8.20 \mathrm{E}-26$ & $31 \%$ & $45 \%$ & $2 \%$ & 3 \\
\hline 3T4M_D & 102.1 & $8.20 \mathrm{E}-26$ & $31 \%$ & $45 \%$ & $2 \%$ & 3 \\
\hline 3T4M_E & 102.1 & $8.20 \mathrm{E}-26$ & $31 \%$ & $45 \%$ & $2 \%$ & 3 \\
\hline 3T4M_F & 102.1 & $8.20 \mathrm{E}-26$ & $31 \%$ & $45 \%$ & $2 \%$ & 3 \\
\hline 3T4M_G & 102.1 & $8.20 \mathrm{E}-26$ & $31 \%$ & $45 \%$ & $2 \%$ & 3 \\
\hline 3T4M_H & 102.1 & $8.20 \mathrm{E}-26$ & $31 \%$ & $45 \%$ & $2 \%$ & 3 \\
\hline 3T4M_I & 102.1 & $8.20 \mathrm{E}-26$ & $31 \%$ & $45 \%$ & $2 \%$ & 3 \\
\hline 3T4M_J & 102.1 & $8.20 \mathrm{E}-26$ & $31 \%$ & $45 \%$ & $2 \%$ & 3 \\
\hline 3UU4_A & 33.1 & 0.12 & $24 \%$ & $43 \%$ & $13 \%$ & 3.05 \\
\hline 3UU4_B & 33.1 & 0.12 & $24 \%$ & $43 \%$ & $13 \%$ & 3.05 \\
\hline 3UU4_C & 33.1 & 0.12 & $24 \%$ & $43 \%$ & $13 \%$ & 3.05 \\
\hline 3UU4_D & 33.1 & 0.12 & $24 \%$ & $43 \%$ & $13 \%$ & 3.05 \\
\hline 3UU4_E & 33.1 & 0.12 & $24 \%$ & $43 \%$ & $13 \%$ & 3.05 \\
\hline 3RQU_A & 42.4 & 0.00013 & $22 \%$ & $41 \%$ & $5 \%$ & 3.09 \\
\hline 3RQU_B & 42.4 & 0.00013 & $22 \%$ & $41 \%$ & $5 \%$ & 3.09 \\
\hline
\end{tabular}




\section{Continued}

\begin{tabular}{|c|c|c|c|c|c|c|}
\hline 3RQU_C & 42.4 & 0.00013 & $22 \%$ & $41 \%$ & $5 \%$ & 3.09 \\
\hline 3RQU_D & 42.4 & 0.00013 & $22 \%$ & $41 \%$ & $5 \%$ & 3.09 \\
\hline 3RQU_E & 42.4 & 0.00013 & $22 \%$ & $41 \%$ & $5 \%$ & 3.09 \\
\hline 3RQU_F & 42.4 & 0.00013 & $22 \%$ & $41 \%$ & $5 \%$ & 3.09 \\
\hline 3RQU_G & 42.4 & 0.00013 & $22 \%$ & $41 \%$ & $5 \%$ & 3.09 \\
\hline 3RQU_H & 42.4 & 0.00013 & $22 \%$ & $41 \%$ & $5 \%$ & 3.09 \\
\hline 3RQU_I & 42.4 & 0.00013 & $22 \%$ & $41 \%$ & $5 \%$ & 3.09 \\
\hline 3RQU_J & 42.4 & 0.00013 & $22 \%$ & $41 \%$ & $5 \%$ & 3.09 \\
\hline 3EHZ_A & 37.7 & 0.0046 & $24 \%$ & $42 \%$ & $11 \%$ & 3.1 \\
\hline 3EHZ_B & 37.7 & 0.0046 & $24 \%$ & $42 \%$ & $11 \%$ & 3.1 \\
\hline 3EHZ_C & 37.7 & 0.0046 & $24 \%$ & $42 \%$ & $11 \%$ & 3.1 \\
\hline 3EHZ_D & 37.7 & 0.0046 & $24 \%$ & $42 \%$ & $11 \%$ & 3.1 \\
\hline 3EHZ_E & 37.7 & 0.0046 & $24 \%$ & $42 \%$ & $11 \%$ & 3.1 \\
\hline 3GUA_A & 87.8 & $9.10 \mathrm{E}-21$ & $28 \%$ & $43 \%$ & $2 \%$ & 3.1 \\
\hline 3GUA_B & 87.8 & $9.10 \mathrm{E}-21$ & $28 \%$ & $43 \%$ & $2 \%$ & 3.1 \\
\hline 3GUA_C & 87.8 & $9.10 \mathrm{E}-21$ & $28 \%$ & $43 \%$ & $2 \%$ & 3.1 \\
\hline 3GUA_D & 87.8 & $9.10 \mathrm{E}-21$ & $28 \%$ & $43 \%$ & $2 \%$ & 3.1 \\
\hline 3GUA_E & 87.8 & $9.10 \mathrm{E}-21$ & $28 \%$ & $43 \%$ & $2 \%$ & 3.1 \\
\hline 3GUA_F & 87.8 & $9.10 \mathrm{E}-21$ & $28 \%$ & $43 \%$ & $2 \%$ & 3.1 \\
\hline 3GUA_G & 87.8 & $9.10 \mathrm{E}-21$ & $28 \%$ & $43 \%$ & $2 \%$ & 3.1 \\
\hline 3GUA_H & 87.8 & $9.10 \mathrm{E}-21$ & $28 \%$ & $43 \%$ & $2 \%$ & 3.1 \\
\hline 3GUA_I & 87.8 & $9.10 \mathrm{E}-21$ & $28 \%$ & $43 \%$ & $2 \%$ & 3.1 \\
\hline 3GUA_J & 87.8 & $9.10 \mathrm{E}-21$ & $28 \%$ & $43 \%$ & $2 \%$ & 3.1 \\
\hline 3SQ9_A & 104.4 & $6.40 \mathrm{E}-27$ & $31 \%$ & $48 \%$ & $3 \%$ & 3.1 \\
\hline 3SQ9_B & 104.4 & $6.40 \mathrm{E}-27$ & $31 \%$ & $48 \%$ & $3 \%$ & 3.1 \\
\hline 3SQ9_C & 104.4 & $6.40 \mathrm{E}-27$ & $31 \%$ & $48 \%$ & $3 \%$ & 3.1 \\
\hline 3SQ9_D & 104.4 & $6.40 \mathrm{E}-27$ & $31 \%$ & $48 \%$ & $3 \%$ & 3.1 \\
\hline 3SQ9_E & 104.4 & $6.40 \mathrm{E}-27$ & $31 \%$ & $48 \%$ & $3 \%$ & 3.1 \\
\hline 3SQ9_F & 104.4 & $6.40 \mathrm{E}-27$ & $31 \%$ & $48 \%$ & $3 \%$ & 3.1 \\
\hline 3SQ9_G & 104.4 & $6.40 \mathrm{E}-27$ & $31 \%$ & $48 \%$ & $3 \%$ & 3.1 \\
\hline 3SQ9_H & 104.4 & $6.40 \mathrm{E}-27$ & $31 \%$ & $48 \%$ & $3 \%$ & 3.1 \\
\hline 3SQ9_I & 104.4 & $6.40 \mathrm{E}-27$ & $31 \%$ & $48 \%$ & $3 \%$ & 3.1 \\
\hline 3SQ9_J & 104.4 & $6.40 \mathrm{E}-27$ & $31 \%$ & $48 \%$ & $3 \%$ & 3.1 \\
\hline 2XZ6_A & 87.8 & $9.30 \mathrm{E}-21$ & $29 \%$ & $43 \%$ & $2 \%$ & 3.137 \\
\hline 2XZ6_B & 87.8 & $9.30 \mathrm{E}-21$ & $29 \%$ & $43 \%$ & $2 \%$ & 3.137 \\
\hline 2XZ6_C & 87.8 & $9.30 \mathrm{E}-21$ & $29 \%$ & $43 \%$ & $2 \%$ & 3.137 \\
\hline 2XZ6_D & 87.8 & $9.30 \mathrm{E}-21$ & $29 \%$ & $43 \%$ & $2 \%$ & 3.137 \\
\hline
\end{tabular}




\section{Continued}

\begin{tabular}{|c|c|c|c|c|c|c|}
\hline 2XZ6_E & 87.8 & $9.30 \mathrm{E}-21$ & $29 \%$ & $43 \%$ & $2 \%$ & 3.137 \\
\hline 2XZ6_F & 87.8 & $9.30 \mathrm{E}-21$ & $29 \%$ & $43 \%$ & $2 \%$ & 3.137 \\
\hline 2XZ6_G & 87.8 & $9.30 \mathrm{E}-21$ & $29 \%$ & $43 \%$ & $2 \%$ & 3.137 \\
\hline 2XZ6_H & 87.8 & $9.30 \mathrm{E}-21$ & $29 \%$ & $43 \%$ & $2 \%$ & 3.137 \\
\hline 2XZ6_I & 87.8 & $9.30 \mathrm{E}-21$ & $29 \%$ & $43 \%$ & $2 \%$ & 3.137 \\
\hline 2XZ6_J & 87.8 & $9.30 \mathrm{E}-21$ & $29 \%$ & $43 \%$ & $2 \%$ & 3.137 \\
\hline 3UU3_A & 33.5 & 0.12 & $24 \%$ & $43 \%$ & $13 \%$ & 3.15 \\
\hline 3UU3_B & 33.5 & 0.12 & $24 \%$ & $43 \%$ & $13 \%$ & 3.15 \\
\hline 3UU3_C & 33.5 & 0.12 & $24 \%$ & $43 \%$ & $13 \%$ & 3.15 \\
\hline 3UU3_D & 33.5 & 0.12 & $24 \%$ & $43 \%$ & $13 \%$ & 3.15 \\
\hline 3UU3_E & 33.5 & 0.12 & $24 \%$ & $43 \%$ & $13 \%$ & 3.15 \\
\hline 3LSV_A & 36.6 & 0.0093 & $25 \%$ & $44 \%$ & $13 \%$ & 3.15 \\
\hline 3LSV_B & 36.6 & 0.0093 & $25 \%$ & $44 \%$ & $13 \%$ & 3.15 \\
\hline 3LSV_C & 36.6 & 0.0093 & $25 \%$ & $44 \%$ & $13 \%$ & 3.15 \\
\hline 3LSV_D & 36.6 & 0.0093 & $25 \%$ & $44 \%$ & $13 \%$ & 3.15 \\
\hline 3LSV_E & 36.6 & 0.0093 & $25 \%$ & $44 \%$ & $13 \%$ & 3.15 \\
\hline 2XQ9_A & 37.7 & 0.0045 & $24 \%$ & $42 \%$ & $11 \%$ & 3.2 \\
\hline 2XQ9_B & 37.7 & 0.0045 & $24 \%$ & $42 \%$ & $11 \%$ & 3.2 \\
\hline 2XQ9_C & 37.7 & 0.0045 & $24 \%$ & $42 \%$ & $11 \%$ & 3.2 \\
\hline 2XQ9_D & 37.7 & 0.0045 & $24 \%$ & $42 \%$ & $11 \%$ & 3.2 \\
\hline 2XQ9_E & 37.7 & 0.0045 & $24 \%$ & $42 \%$ & $11 \%$ & 3.2 \\
\hline 3P4W_A & 36.6 & 0.0089 & $25 \%$ & $44 \%$ & $13 \%$ & 3.2 \\
\hline 3P4W_B & 36.6 & 0.0089 & $25 \%$ & $44 \%$ & $13 \%$ & 3.2 \\
\hline 3P4W_C & 36.6 & 0.0089 & $25 \%$ & $44 \%$ & $13 \%$ & 3.2 \\
\hline 3P4W_D & 36.6 & 0.0089 & $25 \%$ & $44 \%$ & $13 \%$ & 3.2 \\
\hline 3P4W_E & 36.6 & 0.0089 & $25 \%$ & $44 \%$ & $13 \%$ & 3.2 \\
\hline 3TLS_A & 36.6 & 0.0094 & $25 \%$ & $44 \%$ & $13 \%$ & 3.2 \\
\hline 3TLS_B & 36.6 & 0.0094 & $25 \%$ & $44 \%$ & $13 \%$ & 3.2 \\
\hline 3TLS_C & 36.6 & 0.0094 & $25 \%$ & $44 \%$ & $13 \%$ & 3.2 \\
\hline 3TLS_D & 36.6 & 0.0094 & $25 \%$ & $44 \%$ & $13 \%$ & 3.2 \\
\hline 3TLS_E & 36.6 & 0.0094 & $25 \%$ & $44 \%$ & $13 \%$ & 3.2 \\
\hline 4AFT_A & 89.4 & $3.00 \mathrm{E}-21$ & $29 \%$ & $43 \%$ & $2 \%$ & 3.2 \\
\hline 4AFT_B & 89.4 & $3.00 \mathrm{E}-21$ & $29 \%$ & $43 \%$ & $2 \%$ & 3.2 \\
\hline 4AFT_C & 89.4 & $3.00 \mathrm{E}-21$ & $29 \%$ & $43 \%$ & $2 \%$ & 3.2 \\
\hline 4AFT_D & 89.4 & $3.00 \mathrm{E}-21$ & $29 \%$ & $43 \%$ & $2 \%$ & 3.2 \\
\hline 4AFT_E & 89.4 & $3.00 \mathrm{E}-21$ & $29 \%$ & $43 \%$ & $2 \%$ & 3.2 \\
\hline 2XNT_A & 90.9 & $9.90 \mathrm{E}-22$ & $27 \%$ & $44 \%$ & $2 \%$ & 3.21 \\
\hline
\end{tabular}




\section{Continued}

\begin{tabular}{|c|c|c|c|c|c|c|}
\hline 2XNT_B & 90.9 & $9.90 \mathrm{E}-22$ & $27 \%$ & $44 \%$ & $2 \%$ & 3.21 \\
\hline 2XNT_C & 90.9 & $9.90 \mathrm{E}-22$ & $27 \%$ & $44 \%$ & $2 \%$ & 3.21 \\
\hline 2XNT_D & 90.9 & $9.90 \mathrm{E}-22$ & $27 \%$ & $44 \%$ & $2 \%$ & 3.21 \\
\hline 2XNT_E & 90.9 & $9.90 \mathrm{E}-22$ & $27 \%$ & $44 \%$ & $2 \%$ & 3.21 \\
\hline 2XNT_F & 90.9 & $9.90 \mathrm{E}-22$ & $27 \%$ & $44 \%$ & $2 \%$ & 3.21 \\
\hline 2XNT_G & 90.9 & $9.90 \mathrm{E}-22$ & $27 \%$ & $44 \%$ & $2 \%$ & 3.21 \\
\hline 2XNT_H & 90.9 & $9.90 \mathrm{E}-22$ & $27 \%$ & $44 \%$ & $2 \%$ & 3.21 \\
\hline 2XNT_I & 90.9 & $9.90 \mathrm{E}-22$ & $27 \%$ & $44 \%$ & $2 \%$ & 3.21 \\
\hline 2XNT_J & 90.9 & $9.90 \mathrm{E}-22$ & $27 \%$ & $44 \%$ & $2 \%$ & 3.21 \\
\hline 3UU8_A & 33.1 & 0.12 & $24 \%$ & $43 \%$ & $13 \%$ & 3.25 \\
\hline 3UU8_B & 33.1 & 0.12 & $24 \%$ & $43 \%$ & $13 \%$ & 3.25 \\
\hline 3UU8_C & 33.1 & 0.12 & $24 \%$ & $43 \%$ & $13 \%$ & 3.25 \\
\hline 3UU8_D & 33.1 & 0.12 & $24 \%$ & $43 \%$ & $13 \%$ & 3.25 \\
\hline 3UU8_E & 33.1 & 0.12 & $24 \%$ & $43 \%$ & $13 \%$ & 3.25 \\
\hline 2Y58_A & 89.4 & $3.00 \mathrm{E}-21$ & $29 \%$ & $43 \%$ & $2 \%$ & 3.25 \\
\hline 2Y58_B & 89.4 & $3.00 \mathrm{E}-21$ & $29 \%$ & $43 \%$ & $2 \%$ & 3.25 \\
\hline 2Y58_C & 89.4 & $3.00 \mathrm{E}-21$ & $29 \%$ & $43 \%$ & $2 \%$ & 3.25 \\
\hline 2Y58_D & 89.4 & $3.00 \mathrm{E}-21$ & $29 \%$ & $43 \%$ & $2 \%$ & 3.25 \\
\hline 2Y58_E & 89.4 & $3.00 \mathrm{E}-21$ & $29 \%$ & $43 \%$ & $2 \%$ & 3.25 \\
\hline 3RHW_A & 45.1 & $1.70 \mathrm{E}-05$ & $23 \%$ & $42 \%$ & $8 \%$ & 3.26 \\
\hline 3RHW_B & 45.1 & $1.70 \mathrm{E}-05$ & $23 \%$ & $42 \%$ & $8 \%$ & 3.26 \\
\hline 3RHW_C & 45.1 & $1.70 \mathrm{E}-05$ & $23 \%$ & $42 \%$ & $8 \%$ & 3.26 \\
\hline 3RHW_D & 45.1 & $1.70 \mathrm{E}-05$ & $23 \%$ & $42 \%$ & $8 \%$ & 3.26 \\
\hline 3RHW_E & 45.1 & $1.70 \mathrm{E}-05$ & $23 \%$ & $42 \%$ & $8 \%$ & 3.26 \\
\hline 2VL0_A & 43.9 & $3.60 \mathrm{E}-05$ & $22 \%$ & $41 \%$ & $4 \%$ & 3.3 \\
\hline 2VL0_B & 43.9 & $3.60 \mathrm{E}-05$ & $22 \%$ & $41 \%$ & $4 \%$ & 3.3 \\
\hline 2VL0_C & 43.9 & $3.60 \mathrm{E}-05$ & $22 \%$ & $41 \%$ & $4 \%$ & 3.3 \\
\hline 2VL0_D & 43.9 & $3.60 \mathrm{E}-05$ & $22 \%$ & $41 \%$ & $4 \%$ & 3.3 \\
\hline 2VL0_E & 43.9 & $3.60 \mathrm{E}-05$ & $22 \%$ & $41 \%$ & $4 \%$ & 3.3 \\
\hline 2VL0_F & 43.9 & $3.60 \mathrm{E}-05$ & $22 \%$ & $41 \%$ & $4 \%$ & 3.3 \\
\hline 2VL0_G & 43.9 & $3.60 \mathrm{E}-05$ & $22 \%$ & $41 \%$ & $4 \%$ & 3.3 \\
\hline 2VL0_H & 43.9 & $3.60 \mathrm{E}-05$ & $22 \%$ & $41 \%$ & $4 \%$ & 3.3 \\
\hline 2VL0_I & 43.9 & $3.60 \mathrm{E}-05$ & $22 \%$ & $41 \%$ & $4 \%$ & 3.3 \\
\hline 2VL0_J & 43.9 & $3.60 \mathrm{E}-05$ & $22 \%$ & $41 \%$ & $4 \%$ & 3.3 \\
\hline 2YKS_A & 43.9 & $3.60 \mathrm{E}-05$ & $22 \%$ & $41 \%$ & $4 \%$ & 3.3 \\
\hline 2YKS_B & 43.9 & $3.60 \mathrm{E}-05$ & $22 \%$ & $41 \%$ & $4 \%$ & 3.3 \\
\hline 2YKS_C & 43.9 & $3.60 \mathrm{E}-05$ & $22 \%$ & $41 \%$ & $4 \%$ & 3.3 \\
\hline
\end{tabular}




\section{Continued}

\begin{tabular}{|c|c|c|c|c|c|c|}
\hline 2YKS_D & 43.9 & $3.60 \mathrm{E}-05$ & $22 \%$ & $41 \%$ & $4 \%$ & 3.3 \\
\hline 2YKS_E & 43.9 & $3.60 \mathrm{E}-05$ & $22 \%$ & $41 \%$ & $4 \%$ & 3.3 \\
\hline 2YKS_F & 43.9 & $3.60 \mathrm{E}-05$ & $22 \%$ & $41 \%$ & $4 \%$ & 3.3 \\
\hline 2YKS_G & 43.9 & $3.60 \mathrm{E}-05$ & $22 \%$ & $41 \%$ & $4 \%$ & 3.3 \\
\hline 2YKS_H & 43.9 & $3.60 \mathrm{E}-05$ & $22 \%$ & $41 \%$ & $4 \%$ & 3.3 \\
\hline 2YKS_I & 43.9 & $3.60 \mathrm{E}-05$ & $22 \%$ & $41 \%$ & $4 \%$ & 3.3 \\
\hline 2YKS_J & 43.9 & $3.60 \mathrm{E}-05$ & $22 \%$ & $41 \%$ & $4 \%$ & 3.3 \\
\hline 3P50_A & 36.6 & 0.0089 & $25 \%$ & $44 \%$ & $13 \%$ & 3.3 \\
\hline 3P50_B & 36.6 & 0.0089 & $25 \%$ & $44 \%$ & $13 \%$ & 3.3 \\
\hline 3P50_C & 36.6 & 0.0089 & $25 \%$ & $44 \%$ & $13 \%$ & 3.3 \\
\hline 3P50_D & 36.6 & 0.0089 & $25 \%$ & $44 \%$ & $13 \%$ & 3.3 \\
\hline 3P50_E & 36.6 & 0.0089 & $25 \%$ & $44 \%$ & $13 \%$ & 3.3 \\
\hline 3TLT_A & 37 & 0.0083 & $25 \%$ & $44 \%$ & $13 \%$ & 3.3 \\
\hline 3TLT_B & 37 & 0.0083 & $25 \%$ & $44 \%$ & $13 \%$ & 3.3 \\
\hline 3TLT_C & 37 & 0.0083 & $25 \%$ & $44 \%$ & $13 \%$ & 3.3 \\
\hline 3TLT_D & 37 & 0.0083 & $25 \%$ & $44 \%$ & $13 \%$ & 3.3 \\
\hline 3TLT_E & 37 & 0.0083 & $25 \%$ & $44 \%$ & $13 \%$ & 3.3 \\
\hline 2Y57_A & 89.4 & $3.00 \mathrm{E}-21$ & $29 \%$ & $43 \%$ & $2 \%$ & 3.3 \\
\hline 2Y57_B & 89.4 & $3.00 \mathrm{E}-21$ & $29 \%$ & $43 \%$ & $2 \%$ & 3.3 \\
\hline 2Y57_C & 89.4 & $3.00 \mathrm{E}-21$ & $29 \%$ & $43 \%$ & $2 \%$ & 3.3 \\
\hline 2Y57_D & 89.4 & $3.00 \mathrm{E}-21$ & $29 \%$ & $43 \%$ & $2 \%$ & 3.3 \\
\hline 2Y57_E & 89.4 & $3.00 \mathrm{E}-21$ & $29 \%$ & $43 \%$ & $2 \%$ & 3.3 \\
\hline 2YN6_A & 42.4 & 0.00013 & $22 \%$ & $41 \%$ & $5 \%$ & 3.31 \\
\hline 2YN6_B & 42.4 & 0.00013 & $22 \%$ & $41 \%$ & $5 \%$ & 3.31 \\
\hline 2YN6_C & 42.4 & 0.00013 & $22 \%$ & $41 \%$ & $5 \%$ & 3.31 \\
\hline 2YN6_D & 42.4 & 0.00013 & $22 \%$ & $41 \%$ & $5 \%$ & 3.31 \\
\hline 2YN6_E & 42.4 & 0.00013 & $22 \%$ & $41 \%$ & $5 \%$ & 3.31 \\
\hline 4A97_A & 41.2 & 0.00027 & $21 \%$ & $41 \%$ & $4 \%$ & 3.34 \\
\hline 4A97_B & 41.2 & 0.00027 & $21 \%$ & $41 \%$ & $4 \%$ & 3.34 \\
\hline 4A97_C & 41.2 & 0.00027 & $21 \%$ & $41 \%$ & $4 \%$ & 3.34 \\
\hline 4A97_D & 41.2 & 0.00027 & $21 \%$ & $41 \%$ & $4 \%$ & 3.34 \\
\hline 4A97_E & 41.2 & 0.00027 & $21 \%$ & $41 \%$ & $4 \%$ & 3.34 \\
\hline 4A97_F & 41.2 & 0.00027 & $21 \%$ & $41 \%$ & $4 \%$ & 3.34 \\
\hline 4A97_G & 41.2 & 0.00027 & $21 \%$ & $41 \%$ & $4 \%$ & 3.34 \\
\hline 4A97_H & 41.2 & 0.00027 & $21 \%$ & $41 \%$ & $4 \%$ & 3.34 \\
\hline 4A97_I & 41.2 & 0.00027 & $21 \%$ & $41 \%$ & $4 \%$ & 3.34 \\
\hline 4A97_J & 41.2 & 0.00027 & $21 \%$ & $41 \%$ & $4 \%$ & 3.34 \\
\hline
\end{tabular}


S. Mao et al.

\section{Continued}

\begin{tabular}{|c|c|c|c|c|c|c|}
\hline 3RIF_A & 45.1 & $1.70 \mathrm{E}-05$ & $23 \%$ & $42 \%$ & $8 \%$ & 3.35 \\
\hline 3RIF_B & 45.1 & $1.70 \mathrm{E}-05$ & $23 \%$ & $42 \%$ & $8 \%$ & 3.35 \\
\hline 3RIF_C & 45.1 & $1.70 \mathrm{E}-05$ & $23 \%$ & $42 \%$ & $8 \%$ & 3.35 \\
\hline 3RIF_D & 45.1 & $1.70 \mathrm{E}-05$ & $23 \%$ & $42 \%$ & $8 \%$ & 3.35 \\
\hline 3RIF_E & 45.1 & $1.70 \mathrm{E}-05$ & $23 \%$ & $42 \%$ & $8 \%$ & 3.35 \\
\hline 3RI5_A & 45.1 & $1.70 \mathrm{E}-05$ & $23 \%$ & $42 \%$ & $8 \%$ & 3.4 \\
\hline 3RI5_B & 45.1 & $1.70 \mathrm{E}-05$ & $23 \%$ & $42 \%$ & $8 \%$ & 3.4 \\
\hline 3RI5_C & 45.1 & $1.70 \mathrm{E}-05$ & $23 \%$ & $42 \%$ & $8 \%$ & 3.4 \\
\hline 3RI5_D & 45.1 & $1.70 \mathrm{E}-05$ & $23 \%$ & $42 \%$ & $8 \%$ & 3.4 \\
\hline 3RI5_E & 45.1 & $1.70 \mathrm{E}-05$ & $23 \%$ & $42 \%$ & $8 \%$ & 3.4 \\
\hline 2XQ7_A & 37.7 & 0.0046 & $24 \%$ & $42 \%$ & $11 \%$ & 3.4 \\
\hline 2XQ7_B & 37.7 & 0.0046 & $24 \%$ & $42 \%$ & $11 \%$ & 3.4 \\
\hline 2XQ7_C & 37.7 & 0.0046 & $24 \%$ & $42 \%$ & $11 \%$ & 3.4 \\
\hline 2XQ7_D & 37.7 & 0.0046 & $24 \%$ & $42 \%$ & $11 \%$ & 3.4 \\
\hline 2XQ7_E & 37.7 & 0.0046 & $24 \%$ & $42 \%$ & $11 \%$ & 3.4 \\
\hline 2BYQ_A & 87.8 & $1.00 \mathrm{E}-20$ & $28 \%$ & $43 \%$ & $2 \%$ & 3.4 \\
\hline 2BYQ_B & 87.8 & $1.00 \mathrm{E}-20$ & $28 \%$ & $43 \%$ & $2 \%$ & 3.4 \\
\hline 2BYQ_C & 87.8 & $1.00 \mathrm{E}-20$ & $28 \%$ & $43 \%$ & $2 \%$ & 3.4 \\
\hline 2BYQ_D & 87.8 & $1.00 \mathrm{E}-20$ & $28 \%$ & $43 \%$ & $2 \%$ & 3.4 \\
\hline 2BYQ_E & 87.8 & $1.00 \mathrm{E}-20$ & $28 \%$ & $43 \%$ & $2 \%$ & 3.4 \\
\hline 3UQ4_A & 43.1 & $6.30 \mathrm{E}-05$ & $22 \%$ & $41 \%$ & $5 \%$ & 3.5 \\
\hline 3UQ4_B & 43.1 & $6.30 \mathrm{E}-05$ & $22 \%$ & $41 \%$ & $5 \%$ & 3.5 \\
\hline 3UQ4_C & 43.1 & $6.30 \mathrm{E}-05$ & $22 \%$ & $41 \%$ & $5 \%$ & 3.5 \\
\hline 3UQ4_D & 43.1 & $6.30 \mathrm{E}-05$ & $22 \%$ & $41 \%$ & $5 \%$ & 3.5 \\
\hline 3UQ4_E & 43.1 & $6.30 \mathrm{E}-05$ & $22 \%$ & $41 \%$ & $5 \%$ & 3.5 \\
\hline 3UQ4_F & 43.1 & $6.30 \mathrm{E}-05$ & $22 \%$ & $41 \%$ & $5 \%$ & 3.5 \\
\hline 3UQ4_G & 43.1 & $6.30 \mathrm{E}-05$ & $22 \%$ & $41 \%$ & $5 \%$ & 3.5 \\
\hline 3UQ4_H & 43.1 & $6.30 \mathrm{E}-05$ & $22 \%$ & $41 \%$ & $5 \%$ & 3.5 \\
\hline 3UQ4_I & 43.1 & $6.30 \mathrm{E}-05$ & $22 \%$ & $41 \%$ & $5 \%$ & 3.5 \\
\hline 3UQ4_J & 43.1 & $6.30 \mathrm{E}-05$ & $22 \%$ & $41 \%$ & $5 \%$ & 3.5 \\
\hline 2XQ3_A & 37.7 & 0.0046 & $24 \%$ & $42 \%$ & $11 \%$ & 3.5 \\
\hline 2XQ3_B & 37.7 & 0.0046 & $24 \%$ & $42 \%$ & $11 \%$ & 3.5 \\
\hline 2XQ3_C & 37.7 & 0.0046 & $24 \%$ & $42 \%$ & $11 \%$ & 3.5 \\
\hline 2XQ3_D & 37.7 & 0.0046 & $24 \%$ & $42 \%$ & $11 \%$ & 3.5 \\
\hline 2XQ3_E & 37.7 & 0.0046 & $24 \%$ & $42 \%$ & $11 \%$ & 3.5 \\
\hline 2XQ5_A & 37.7 & 0.0046 & $24 \%$ & $42 \%$ & $11 \%$ & 3.5 \\
\hline 2XQ5_B & 37.7 & 0.0046 & $24 \%$ & $42 \%$ & $11 \%$ & 3.5 \\
\hline 2XQ5_C & 37.7 & 0.0046 & $24 \%$ & $42 \%$ & $11 \%$ & 3.5 \\
\hline 2XQ5_D & 37.7 & 0.0046 & $24 \%$ & $42 \%$ & $11 \%$ & 3.5 \\
\hline 2XQ5_E & 37.7 & 0.0046 & $24 \%$ & $42 \%$ & $11 \%$ & 3.5 \\
\hline
\end{tabular}




\section{Continued}

\begin{tabular}{|c|c|c|c|c|c|c|}
\hline 3EI0_A & 37.7 & 0.0048 & $24 \%$ & $42 \%$ & $11 \%$ & 3.5 \\
\hline 3EI0_B & 37.7 & 0.0048 & $24 \%$ & $42 \%$ & $11 \%$ & 3.5 \\
\hline 3EIO_C & 37.7 & 0.0048 & $24 \%$ & $42 \%$ & $11 \%$ & 3.5 \\
\hline 3EI0_D & 37.7 & 0.0048 & $24 \%$ & $42 \%$ & $11 \%$ & 3.5 \\
\hline 3EI0_E & 37.7 & 0.0048 & $24 \%$ & $42 \%$ & $11 \%$ & 3.5 \\
\hline 2Y56_A & 89.4 & $3.00 \mathrm{E}-21$ & $29 \%$ & $43 \%$ & $2 \%$ & 3.59 \\
\hline 2Y56_B & 89.4 & $3.00 \mathrm{E}-21$ & $29 \%$ & $43 \%$ & $2 \%$ & 3.59 \\
\hline 2Y56_C & 89.4 & $3.00 \mathrm{E}-21$ & $29 \%$ & $43 \%$ & $2 \%$ & 3.59 \\
\hline 2Y56_D & 89.4 & $3.00 \mathrm{E}-21$ & $29 \%$ & $43 \%$ & $2 \%$ & 3.59 \\
\hline 2Y56_E & 89.4 & $3.00 \mathrm{E}-21$ & $29 \%$ & $43 \%$ & $2 \%$ & 3.59 \\
\hline 2XQ4_A & 37.7 & 0.0046 & $24 \%$ & $42 \%$ & $11 \%$ & 3.6 \\
\hline 2XQ4_B & 37.7 & 0.0046 & $24 \%$ & $42 \%$ & $11 \%$ & 3.6 \\
\hline 2XQ4_C & 37.7 & 0.0046 & $24 \%$ & $42 \%$ & $11 \%$ & 3.6 \\
\hline 2XQ4_D & 37.7 & 0.0046 & $24 \%$ & $42 \%$ & $11 \%$ & 3.6 \\
\hline 2XQ4_E & 37.7 & 0.0046 & $24 \%$ & $42 \%$ & $11 \%$ & 3.6 \\
\hline 2XQ8_A & 37.7 & 0.0046 & $24 \%$ & $42 \%$ & $11 \%$ & 3.6 \\
\hline 2XQ8_B & 37.7 & 0.0046 & $24 \%$ & $42 \%$ & $11 \%$ & 3.6 \\
\hline 2XQ8_C & 37.7 & 0.0046 & $24 \%$ & $42 \%$ & $11 \%$ & 3.6 \\
\hline 2XQ8_D & 37.7 & 0.0046 & $24 \%$ & $42 \%$ & $11 \%$ & 3.6 \\
\hline 2XQ8_E & 37.7 & 0.0046 & $24 \%$ & $42 \%$ & $11 \%$ & 3.6 \\
\hline 4A98_A & 41.2 & 0.00027 & $21 \%$ & $41 \%$ & $4 \%$ & 3.61 \\
\hline 4A98_B & 41.2 & 0.00027 & $21 \%$ & $41 \%$ & $4 \%$ & 3.61 \\
\hline 4A98_C & 41.2 & 0.00027 & $21 \%$ & $41 \%$ & $4 \%$ & 3.61 \\
\hline 4A98_D & 41.2 & 0.00027 & $21 \%$ & $41 \%$ & $4 \%$ & 3.61 \\
\hline 4A98_E & 41.2 & 0.00027 & $21 \%$ & $41 \%$ & $4 \%$ & 3.61 \\
\hline 4A98_F & 41.2 & 0.00027 & $21 \%$ & $41 \%$ & $4 \%$ & 3.61 \\
\hline 4A98_G & 41.2 & 0.00027 & $21 \%$ & $41 \%$ & $4 \%$ & 3.61 \\
\hline 4A98_H & 41.2 & 0.00027 & $21 \%$ & $41 \%$ & $4 \%$ & 3.61 \\
\hline 4A98_I & 41.2 & 0.00027 & $21 \%$ & $41 \%$ & $4 \%$ & 3.61 \\
\hline 4A98_J & 41.2 & 0.00027 & $21 \%$ & $41 \%$ & $4 \%$ & 3.61 \\
\hline 3ZKR_A & 41.2 & 0.00027 & $21 \%$ & $41 \%$ & $4 \%$ & 3.65 \\
\hline 3ZKR_B & 41.2 & 0.00027 & $21 \%$ & $41 \%$ & $4 \%$ & 3.65 \\
\hline 3ZKR_C & 41.2 & 0.00027 & $21 \%$ & $41 \%$ & $4 \%$ & 3.65 \\
\hline 3ZKR_D & 41.2 & 0.00027 & $21 \%$ & $41 \%$ & $4 \%$ & 3.65 \\
\hline 3ZKR_E & 41.2 & 0.00027 & $21 \%$ & $41 \%$ & $4 \%$ & 3.65 \\
\hline 3ZKR_F & 41.2 & 0.00027 & $21 \%$ & $41 \%$ & $4 \%$ & 3.65 \\
\hline 3ZKR_G & 41.2 & 0.00027 & $21 \%$ & $41 \%$ & $4 \%$ & 3.65 \\
\hline 3ZKR_H & 41.2 & 0.00027 & $21 \%$ & $41 \%$ & $4 \%$ & 3.65 \\
\hline 3ZKR_I & 41.2 & 0.00027 & $21 \%$ & $41 \%$ & $4 \%$ & 3.65 \\
\hline 3ZKR_J & 41.2 & 0.00027 & $21 \%$ & $41 \%$ & $4 \%$ & 3.65 \\
\hline
\end{tabular}


S. Mao et al.

\section{Continued}

\begin{tabular}{|c|c|c|c|c|c|c|}
\hline 2Y54_A & 89.4 & $3.00 \mathrm{E}-21$ & $29 \%$ & $43 \%$ & $2 \%$ & 3.65 \\
\hline 2Y54_B & 89.4 & $3.00 \mathrm{E}-21$ & $29 \%$ & $43 \%$ & $2 \%$ & 3.65 \\
\hline 2Y54_C & 89.4 & $3.00 \mathrm{E}-21$ & $29 \%$ & $43 \%$ & $2 \%$ & 3.65 \\
\hline 2Y54_D & 89.4 & $3.00 \mathrm{E}-21$ & $29 \%$ & $43 \%$ & $2 \%$ & 3.65 \\
\hline 2Y54_E & 89.4 & $3.00 \mathrm{E}-21$ & $29 \%$ & $43 \%$ & $2 \%$ & 3.65 \\
\hline 2XQ6_A & 37.7 & 0.0046 & $24 \%$ & $42 \%$ & $11 \%$ & 3.7 \\
\hline 2XQ6_B & 37.7 & 0.0046 & $24 \%$ & $42 \%$ & $11 \%$ & 3.7 \\
\hline 2XQ6_C & 37.7 & 0.0046 & $24 \%$ & $42 \%$ & $11 \%$ & 3.7 \\
\hline 2XQ6_D & 37.7 & 0.0046 & $24 \%$ & $42 \%$ & $11 \%$ & 3.7 \\
\hline 2XQ6_E & 37.7 & 0.0046 & $24 \%$ & $42 \%$ & $11 \%$ & 3.7 \\
\hline 2XQA_A & 37.7 & 0.0046 & $24 \%$ & $42 \%$ & $11 \%$ & 3.7 \\
\hline 2XQA_B & 37.7 & 0.0046 & $24 \%$ & $42 \%$ & $11 \%$ & 3.7 \\
\hline 2XQA_C & 37.7 & 0.0046 & $24 \%$ & $42 \%$ & $11 \%$ & 3.7 \\
\hline 2XQA_D & 37.7 & 0.0046 & $24 \%$ & $42 \%$ & $11 \%$ & 3.7 \\
\hline 2XQA_E & 37.7 & 0.0046 & $24 \%$ & $42 \%$ & $11 \%$ & 3.7 \\
\hline 3UQ7_A & 43.1 & $6.50 \mathrm{E}-05$ & $22 \%$ & $41 \%$ & $5 \%$ & 3.8 \\
\hline 3UQ7_B & 43.1 & $6.50 \mathrm{E}-05$ & $22 \%$ & $41 \%$ & $5 \%$ & 3.8 \\
\hline 3UQ7_C & 43.1 & $6.50 \mathrm{E}-05$ & $22 \%$ & $41 \%$ & $5 \%$ & 3.8 \\
\hline 3UQ7_D & 43.1 & $6.50 \mathrm{E}-05$ & $22 \%$ & $41 \%$ & $5 \%$ & 3.8 \\
\hline 3UQ7_E & 43.1 & $6.50 \mathrm{E}-05$ & $22 \%$ & $41 \%$ & $5 \%$ & 3.8 \\
\hline 3UQ7_F & 43.1 & $6.50 \mathrm{E}-05$ & $22 \%$ & $41 \%$ & $5 \%$ & 3.8 \\
\hline 3UQ7_G & 43.1 & $6.50 \mathrm{E}-05$ & $22 \%$ & $41 \%$ & $5 \%$ & 3.8 \\
\hline 3UQ7_H & 43.1 & $6.50 \mathrm{E}-05$ & $22 \%$ & $41 \%$ & $5 \%$ & 3.8 \\
\hline 3UQ7_I & 43.1 & $6.50 \mathrm{E}-05$ & $22 \%$ & $41 \%$ & $5 \%$ & 3.8 \\
\hline 3UQ7_J & 43.1 & $6.50 \mathrm{E}-05$ & $22 \%$ & $41 \%$ & $5 \%$ & 3.8 \\
\hline 3RIA_A & 45.1 & $1.70 \mathrm{E}-05$ & $23 \%$ & $42 \%$ & $8 \%$ & 3.8 \\
\hline 3RIA_B & 45.1 & $1.70 \mathrm{E}-05$ & $23 \%$ & $42 \%$ & $8 \%$ & 3.8 \\
\hline 3RIA_C & 45.1 & $1.70 \mathrm{E}-05$ & $23 \%$ & $42 \%$ & $8 \%$ & 3.8 \\
\hline 3RIA_D & 45.1 & $1.70 \mathrm{E}-05$ & $23 \%$ & $42 \%$ & $8 \%$ & 3.8 \\
\hline 3RIA_E & 45.1 & $1.70 \mathrm{E}-05$ & $23 \%$ & $42 \%$ & $8 \%$ & 3.8 \\
\hline 4AR2_A & 34.7 & 0.056 & $25 \%$ & $47 \%$ & $16 \%$ & 3.8 \\
\hline 2YOE_A & 41.2 & 0.00027 & $21 \%$ & $41 \%$ & $4 \%$ & 3.9 \\
\hline 2YOE_B & 41.2 & 0.00027 & $21 \%$ & $41 \%$ & $4 \%$ & 3.9 \\
\hline 2YOE_C & 41.2 & 0.00027 & $21 \%$ & $41 \%$ & $4 \%$ & 3.9 \\
\hline 2YOE_D & 41.2 & 0.00027 & $21 \%$ & $41 \%$ & $4 \%$ & 3.9 \\
\hline 2YOE_E & 41.2 & 0.00027 & $21 \%$ & $41 \%$ & $4 \%$ & 3.9 \\
\hline 2YOE_F & 41.2 & 0.00027 & $21 \%$ & $41 \%$ & $4 \%$ & 3.9 \\
\hline 2YOE_G & 41.2 & 0.00027 & $21 \%$ & $41 \%$ & $4 \%$ & 3.9 \\
\hline 2YOE_H & 41.2 & 0.00027 & $21 \%$ & $41 \%$ & $4 \%$ & 3.9 \\
\hline 2YOE_I & 41.2 & 0.00027 & $21 \%$ & $41 \%$ & $4 \%$ & 3.9 \\
\hline
\end{tabular}




\section{Continued}

\begin{tabular}{|c|c|c|c|c|c|c|}
\hline 2YOE_J & 41.2 & 0.00027 & $21 \%$ & $41 \%$ & $4 \%$ & 3.9 \\
\hline 2BG9_C & 158.3 & $9.40 \mathrm{E}-46$ & $38 \%$ & $59 \%$ & $3 \%$ & 4 \\
\hline 2BG9_B & 176.8 & $1.10 \mathrm{E}-52$ & $43 \%$ & $62 \%$ & $1 \%$ & 4 \\
\hline 2BG9_E & 174.5 & $8.60 \mathrm{E}-52$ & $43 \%$ & $67 \%$ & $0 \%$ & 4 \\
\hline 2BG9_A & 222.6 & $2.60 \mathrm{E}-70$ & $51 \%$ & $67 \%$ & $0 \%$ & 4 \\
\hline 2BG9_D & 222.6 & $2.60 \mathrm{E}-70$ & $51 \%$ & $67 \%$ & $0 \%$ & 4 \\
\hline 3UQ5_A & 43.1 & $6.20 \mathrm{E}-05$ & $22 \%$ & $41 \%$ & $5 \%$ & 4.2 \\
\hline 3UQ5_B & 43.1 & $6.20 \mathrm{E}-05$ & $22 \%$ & $41 \%$ & $5 \%$ & 4.2 \\
\hline 3UQ5_C & 43.1 & $6.20 \mathrm{E}-05$ & $22 \%$ & $41 \%$ & $5 \%$ & 4.2 \\
\hline 3UQ5_D & 43.1 & $6.20 \mathrm{E}-05$ & $22 \%$ & $41 \%$ & $5 \%$ & 4.2 \\
\hline 3UQ5_E & 43.1 & $6.20 \mathrm{E}-05$ & $22 \%$ & $41 \%$ & $5 \%$ & 4.2 \\
\hline 3UQ5_F & 43.1 & $6.20 \mathrm{E}-05$ & $22 \%$ & $41 \%$ & $5 \%$ & 4.2 \\
\hline 3UQ5_G & 43.1 & $6.20 \mathrm{E}-05$ & $22 \%$ & $41 \%$ & $5 \%$ & 4.2 \\
\hline 3UQ5_H & 43.1 & $6.20 \mathrm{E}-05$ & $22 \%$ & $41 \%$ & $5 \%$ & 4.2 \\
\hline 3UQ5_I & 43.1 & $6.20 \mathrm{E}-05$ & $22 \%$ & $41 \%$ & $5 \%$ & 4.2 \\
\hline 3UQ5_J & 43.1 & $6.20 \mathrm{E}-05$ & $22 \%$ & $41 \%$ & $5 \%$ & 4.2 \\
\hline 1YI5_A & 63.5 & $2.00 \mathrm{E}-12$ & $26 \%$ & $41 \%$ & $7 \%$ & 4.2 \\
\hline 1YI5_B & 63.5 & $2.00 \mathrm{E}-12$ & $26 \%$ & $41 \%$ & $7 \%$ & 4.2 \\
\hline 1YI5_C & 63.5 & $2.00 \mathrm{E}-12$ & $26 \%$ & $41 \%$ & $7 \%$ & 4.2 \\
\hline 1YI5_D & 63.5 & $2.00 \mathrm{E}-12$ & $26 \%$ & $41 \%$ & $7 \%$ & 4.2 \\
\hline 1YI5_E & 63.5 & $2.00 \mathrm{E}-12$ & $26 \%$ & $41 \%$ & $7 \%$ & 4.2 \\
\hline 4AQQ_A & 34.7 & 0.056 & $25 \%$ & $47 \%$ & $16 \%$ & 4.75 \\
\hline 4AOE_A & 73.9 & $5.40 \mathrm{E}-16$ & $24 \%$ & $44 \%$ & $3 \%$ & 5.8 \\
\hline 4AOE_B & 73.9 & $5.40 \mathrm{E}-16$ & $24 \%$ & $44 \%$ & $3 \%$ & 5.8 \\
\hline 4AOE_C & 73.9 & $5.40 \mathrm{E}-16$ & $24 \%$ & $44 \%$ & $3 \%$ & 5.8 \\
\hline 4AOE_D & 73.9 & $5.40 \mathrm{E}-16$ & $24 \%$ & $44 \%$ & $3 \%$ & 5.8 \\
\hline 4AOE_E & 73.9 & $5.40 \mathrm{E}-16$ & $24 \%$ & $44 \%$ & $3 \%$ & 5.8 \\
\hline 4AOD_A & 75.1 & $2.10 \mathrm{E}-16$ & $24 \%$ & $46 \%$ & $3 \%$ & 6 \\
\hline 4AOD_B & 75.1 & $2.10 \mathrm{E}-16$ & $24 \%$ & $46 \%$ & $3 \%$ & 6 \\
\hline 4AOD_C & 75.1 & $2.10 \mathrm{E}-16$ & $24 \%$ & $46 \%$ & $3 \%$ & 6 \\
\hline 4AOD_D & 75.1 & $2.10 \mathrm{E}-16$ & $24 \%$ & $46 \%$ & $3 \%$ & 6 \\
\hline 4AOD_E & 75.1 & $2.10 \mathrm{E}-16$ & $24 \%$ & $46 \%$ & $3 \%$ & 6 \\
\hline 4AQ5_C & 156.4 & $5.40 \mathrm{E}-44$ & $36 \%$ & $57 \%$ & $7 \%$ & 6.2 \\
\hline 4AQ9_C & 156.4 & $5.40 \mathrm{E}-44$ & $36 \%$ & $57 \%$ & $7 \%$ & 6.2 \\
\hline 4AQ5_B & 171 & $1.60 \mathrm{E}-49$ & $41 \%$ & $58 \%$ & $6 \%$ & 6.2 \\
\hline 4AQ9_B & 171 & $1.60 \mathrm{E}-49$ & $41 \%$ & $58 \%$ & $6 \%$ & 6.2 \\
\hline 4AQ5_E & 168.7 & $9.40 \mathrm{E}-49$ & $42 \%$ & $64 \%$ & $4 \%$ & 6.2 \\
\hline 4AQ9_E & 168.7 & $9.40 \mathrm{E}-49$ & $42 \%$ & $64 \%$ & $4 \%$ & 6.2 \\
\hline 4AQ5_A & 222.2 & $2.80 \mathrm{E}-69$ & $51 \%$ & $67 \%$ & $0 \%$ & 6.2 \\
\hline 4AQ5_D & 222.2 & $2.80 \mathrm{E}-69$ & $51 \%$ & $67 \%$ & $0 \%$ & 6.2 \\
\hline 4AQ9_A & 222.2 & $2.80 \mathrm{E}-69$ & $51 \%$ & $67 \%$ & $0 \%$ & 6.2 \\
\hline 4AQ9_D & 222.2 & $2.80 \mathrm{E}-69$ & $51 \%$ & $67 \%$ & $0 \%$ & 6.2 \\
\hline
\end{tabular}


Table S3. Results of search b2 subunit on the PDB. ID consists of PDB ID (the first 4 letters) and the subunit (the last letter).

\begin{tabular}{|c|c|c|c|c|c|c|}
\hline ID & Score & Expect & Identity & Positives & Gaps & Resolution \\
\hline 2R31_A & 28.1 & 4.5 & $53 \%$ & $69 \%$ & $0 \%$ & 1 \\
\hline 2RB8_A & 26.6 & 7.6 & $27 \%$ & $39 \%$ & $19 \%$ & 1.45 \\
\hline 2WN9_A & 63.5 & $2.20 \mathrm{E}-12$ & $24 \%$ & $44 \%$ & $4 \%$ & 1.75 \\
\hline 2WN9_B & 63.5 & $2.20 \mathrm{E}-12$ & $24 \%$ & $44 \%$ & $4 \%$ & 1.75 \\
\hline 2WN9_C & 63.5 & $2.20 \mathrm{E}-12$ & $24 \%$ & $44 \%$ & $4 \%$ & 1.75 \\
\hline 2WN9_D & 63.5 & $2.20 \mathrm{E}-12$ & $24 \%$ & $44 \%$ & $4 \%$ & 1.75 \\
\hline 2WN9_E & 63.5 & $2.20 \mathrm{E}-12$ & $24 \%$ & $44 \%$ & $4 \%$ & 1.75 \\
\hline 2PGZ_A & 63.5 & $2.30 \mathrm{E}-12$ & $24 \%$ & $44 \%$ & $4 \%$ & 1.76 \\
\hline 2PGZ_B & 63.5 & $2.30 \mathrm{E}-12$ & $24 \%$ & $44 \%$ & $4 \%$ & 1.76 \\
\hline 2PGZ_C & 63.5 & $2.30 \mathrm{E}-12$ & $24 \%$ & $44 \%$ & $4 \%$ & 1.76 \\
\hline 2PGZ_D & 63.5 & $2.30 \mathrm{E}-12$ & $24 \%$ & $44 \%$ & $4 \%$ & 1.76 \\
\hline 2PGZ_E & 63.5 & $2.30 \mathrm{E}-12$ & $24 \%$ & $44 \%$ & $4 \%$ & 1.76 \\
\hline 2WNJ_A & 63.5 & $2.20 \mathrm{E}-12$ & $24 \%$ & $44 \%$ & $4 \%$ & 1.8 \\
\hline 2WNJ_B & 63.5 & $2.20 \mathrm{E}-12$ & $24 \%$ & $44 \%$ & $4 \%$ & 1.8 \\
\hline 2WNJ_C & 63.5 & $2.20 \mathrm{E}-12$ & $24 \%$ & $44 \%$ & $4 \%$ & 1.8 \\
\hline 2WNJ_D & 63.5 & $2.20 \mathrm{E}-12$ & $24 \%$ & $44 \%$ & $4 \%$ & 1.8 \\
\hline 2WNJ_E & 63.5 & $2.20 \mathrm{E}-12$ & $24 \%$ & $44 \%$ & $4 \%$ & 1.8 \\
\hline 2ZD2_A & 28.1 & 4.3 & $53 \%$ & $69 \%$ & $0 \%$ & 1.8 \\
\hline 2ZD2_B & 28.1 & 4.3 & $53 \%$ & $69 \%$ & $0 \%$ & 1.8 \\
\hline 4AFH_A & 70.1 & $1.30 \mathrm{E}-14$ & $28 \%$ & $46 \%$ & $8 \%$ & 1.88 \\
\hline 4AFH_B & 70.1 & $1.30 \mathrm{E}-14$ & $28 \%$ & $46 \%$ & $8 \%$ & 1.88 \\
\hline 4AFH_C & 70.1 & $1.30 \mathrm{E}-14$ & $28 \%$ & $46 \%$ & $8 \%$ & 1.88 \\
\hline 4AFH_D & 70.1 & $1.30 \mathrm{E}-14$ & $28 \%$ & $46 \%$ & $8 \%$ & 1.88 \\
\hline 4AFH_E & 70.1 & $1.30 \mathrm{E}-14$ & $28 \%$ & $46 \%$ & $8 \%$ & 1.88 \\
\hline 2Y7Y_A & 63.9 & $1.50 \mathrm{E}-12$ & $25 \%$ & $45 \%$ & $4 \%$ & 1.9 \\
\hline 2Y7Y_B & 63.9 & $1.50 \mathrm{E}-12$ & $25 \%$ & $45 \%$ & $4 \%$ & 1.9 \\
\hline 2Y7Y_C & 63.9 & $1.50 \mathrm{E}-12$ & $25 \%$ & $45 \%$ & $4 \%$ & 1.9 \\
\hline 2Y7Y_D & 63.9 & $1.50 \mathrm{E}-12$ & $25 \%$ & $45 \%$ & $4 \%$ & 1.9 \\
\hline 2Y7Y_E & 63.9 & $1.50 \mathrm{E}-12$ & $25 \%$ & $45 \%$ & $4 \%$ & 1.9 \\
\hline 2P4X_A & 28.1 & 4.5 & $53 \%$ & $69 \%$ & $0 \%$ & 1.9 \\
\hline 2P4X_B & 28.1 & 4.5 & $53 \%$ & $69 \%$ & $0 \%$ & 1.9 \\
\hline 2XYS_A & 63.9 & $1.50 \mathrm{E}-12$ & $25 \%$ & $45 \%$ & $4 \%$ & 1.909 \\
\hline 2XYS_B & 63.9 & $1.50 \mathrm{E}-12$ & $25 \%$ & $45 \%$ & $4 \%$ & 1.909 \\
\hline 2XYS_C & 63.9 & $1.50 \mathrm{E}-12$ & $25 \%$ & $45 \%$ & $4 \%$ & 1.909 \\
\hline 2XYS_D & 63.9 & $1.50 \mathrm{E}-12$ & $25 \%$ & $45 \%$ & $4 \%$ & 1.909 \\
\hline
\end{tabular}




\section{Continued}

\begin{tabular}{|c|c|c|c|c|c|c|}
\hline 2XYS_E & 63.9 & $1.50 \mathrm{E}-12$ & $25 \%$ & $45 \%$ & $4 \%$ & 1.909 \\
\hline 3C84_A & 63.5 & $2.60 \mathrm{E}-12$ & $24 \%$ & $44 \%$ & $4 \%$ & 1.94 \\
\hline 3C84_B & 63.5 & $2.60 \mathrm{E}-12$ & $24 \%$ & $44 \%$ & $4 \%$ & 1.94 \\
\hline 3C84_C & 63.5 & $2.60 \mathrm{E}-12$ & $24 \%$ & $44 \%$ & $4 \%$ & 1.94 \\
\hline 3C84_D & 63.5 & $2.60 \mathrm{E}-12$ & $24 \%$ & $44 \%$ & $4 \%$ & 1.94 \\
\hline 3C84_E & 63.5 & $2.60 \mathrm{E}-12$ & $24 \%$ & $44 \%$ & $4 \%$ & 1.94 \\
\hline 2QC1_B & 176.4 & $2.10 \mathrm{E}-54$ & $42 \%$ & $63 \%$ & $2 \%$ & 1.94 \\
\hline 1OSP_L & 28.1 & 4.8 & $23 \%$ & $42 \%$ & $7 \%$ & 1.95 \\
\hline 2YMD_A & 64.7 & $8.20 \mathrm{E}-13$ & $25 \%$ & $42 \%$ & $1 \%$ & 1.96 \\
\hline 2YMD_B & 64.7 & $8.20 \mathrm{E}-13$ & $25 \%$ & $42 \%$ & $1 \%$ & 1.96 \\
\hline 2YMD_C & 64.7 & $8.20 \mathrm{E}-13$ & $25 \%$ & $42 \%$ & $1 \%$ & 1.96 \\
\hline 2YMD_D & 64.7 & $8.20 \mathrm{E}-13$ & $25 \%$ & $42 \%$ & $1 \%$ & 1.96 \\
\hline 2YMD_E & 64.7 & $8.20 \mathrm{E}-13$ & $25 \%$ & $42 \%$ & $1 \%$ & 1.96 \\
\hline 2YMD_F & 64.7 & $8.20 \mathrm{E}-13$ & $25 \%$ & $42 \%$ & $1 \%$ & 1.96 \\
\hline 2YMD_G & 64.7 & $8.20 \mathrm{E}-13$ & $25 \%$ & $42 \%$ & $1 \%$ & 1.96 \\
\hline 2YMD_H & 64.7 & $8.20 \mathrm{E}-13$ & $25 \%$ & $42 \%$ & $1 \%$ & 1.96 \\
\hline 2YMD_I & 64.7 & $8.20 \mathrm{E}-13$ & $25 \%$ & $42 \%$ & $1 \%$ & 1.96 \\
\hline 2YMD_J & 64.7 & $8.20 \mathrm{E}-13$ & $25 \%$ & $42 \%$ & $1 \%$ & 1.96 \\
\hline 2BJ0_A & 51.6 & $4.10 \mathrm{E}-08$ & $28 \%$ & $48 \%$ & $5 \%$ & 2 \\
\hline 2BJ0_B & 51.6 & $4.10 \mathrm{E}-08$ & $28 \%$ & $48 \%$ & $5 \%$ & 2 \\
\hline 2BJ0_C & 51.6 & $4.10 \mathrm{E}-08$ & $28 \%$ & $48 \%$ & $5 \%$ & 2 \\
\hline 2BJ0_D & 51.6 & $4.10 \mathrm{E}-08$ & $28 \%$ & $48 \%$ & $5 \%$ & 2 \\
\hline 2BJ0_E & 51.6 & $4.10 \mathrm{E}-08$ & $28 \%$ & $48 \%$ & $5 \%$ & 2 \\
\hline 4AFG_A & 70.1 & $1.30 \mathrm{E}-14$ & $28 \%$ & $46 \%$ & $8 \%$ & 2 \\
\hline 4AFG_B & 70.1 & $1.30 \mathrm{E}-14$ & $28 \%$ & $46 \%$ & $8 \%$ & 2 \\
\hline 4AFG_C & 70.1 & $1.30 \mathrm{E}-14$ & $28 \%$ & $46 \%$ & $8 \%$ & 2 \\
\hline 4AFG_D & 70.1 & $1.30 \mathrm{E}-14$ & $28 \%$ & $46 \%$ & $8 \%$ & 2 \\
\hline 4AFG_E & 70.1 & $1.30 \mathrm{E}-14$ & $28 \%$ & $46 \%$ & $8 \%$ & 2 \\
\hline 2BYN_A & 63.5 & $2.60 \mathrm{E}-12$ & $24 \%$ & $44 \%$ & $4 \%$ & 2.02 \\
\hline 2BYN_B & 63.5 & $2.60 \mathrm{E}-12$ & $24 \%$ & $44 \%$ & $4 \%$ & 2.02 \\
\hline 2BYN_C & 63.5 & $2.60 \mathrm{E}-12$ & $24 \%$ & $44 \%$ & $4 \%$ & 2.02 \\
\hline 2BYN_D & 63.5 & $2.60 \mathrm{E}-12$ & $24 \%$ & $44 \%$ & $4 \%$ & 2.02 \\
\hline 2BYN_E & 63.5 & $2.60 \mathrm{E}-12$ & $24 \%$ & $44 \%$ & $4 \%$ & 2.02 \\
\hline 2BYS_A & 63.5 & $2.60 \mathrm{E}-12$ & $24 \%$ & $44 \%$ & $4 \%$ & 2.05 \\
\hline 2BYS_B & 63.5 & $2.60 \mathrm{E}-12$ & $24 \%$ & $44 \%$ & $4 \%$ & 2.05 \\
\hline 2BYS_C & 63.5 & $2.60 \mathrm{E}-12$ & $24 \%$ & $44 \%$ & $4 \%$ & 2.05 \\
\hline 2BYS_D & 63.5 & $2.60 \mathrm{E}-12$ & $24 \%$ & $44 \%$ & $4 \%$ & 2.05 \\
\hline
\end{tabular}




\section{Continued}

\begin{tabular}{|c|c|c|c|c|c|c|}
\hline 2BYS_E & 63.5 & $2.60 \mathrm{E}-12$ & $24 \%$ & $44 \%$ & $4 \%$ & 2.05 \\
\hline 2BYS_F & 63.5 & $2.60 \mathrm{E}-12$ & $24 \%$ & $44 \%$ & $4 \%$ & 2.05 \\
\hline 2BYS_G & 63.5 & $2.60 \mathrm{E}-12$ & $24 \%$ & $44 \%$ & $4 \%$ & 2.05 \\
\hline 2BYS_H & 63.5 & $2.60 \mathrm{E}-12$ & $24 \%$ & $44 \%$ & $4 \%$ & 2.05 \\
\hline 2BYS_I & 63.5 & $2.60 \mathrm{E}-12$ & $24 \%$ & $44 \%$ & $4 \%$ & 2.05 \\
\hline 2BYS_J & 63.5 & $2.60 \mathrm{E}-12$ & $24 \%$ & $44 \%$ & $4 \%$ & 2.05 \\
\hline 2XYT_A & 63.9 & $1.50 \mathrm{E}-12$ & $25 \%$ & $45 \%$ & $4 \%$ & 2.05 \\
\hline 2XYT_B & 63.9 & $1.50 \mathrm{E}-12$ & $25 \%$ & $45 \%$ & $4 \%$ & 2.05 \\
\hline 2XYT_C & 63.9 & $1.50 \mathrm{E}-12$ & $25 \%$ & $45 \%$ & $4 \%$ & 2.05 \\
\hline 2XYT_D & 63.9 & $1.50 \mathrm{E}-12$ & $25 \%$ & $45 \%$ & $4 \%$ & 2.05 \\
\hline 2XYT_E & 63.9 & $1.50 \mathrm{E}-12$ & $25 \%$ & $45 \%$ & $4 \%$ & 2.05 \\
\hline 2XYT_F & 63.9 & $1.50 \mathrm{E}-12$ & $25 \%$ & $45 \%$ & $4 \%$ & 2.05 \\
\hline 2XYT_G & 63.9 & $1.50 \mathrm{E}-12$ & $25 \%$ & $45 \%$ & $4 \%$ & 2.05 \\
\hline 2XYT_H & 63.9 & $1.50 \mathrm{E}-12$ & $25 \%$ & $45 \%$ & $4 \%$ & 2.05 \\
\hline 2XYT_I & 63.9 & $1.50 \mathrm{E}-12$ & $25 \%$ & $45 \%$ & $4 \%$ & 2.05 \\
\hline 2XYT_J & 63.9 & $1.50 \mathrm{E}-12$ & $25 \%$ & $45 \%$ & $4 \%$ & 2.05 \\
\hline 2BYP_A & 63.5 & $2.20 \mathrm{E}-12$ & $24 \%$ & $43 \%$ & $1 \%$ & 2.07 \\
\hline 2BYP_B & 63.5 & $2.20 \mathrm{E}-12$ & $24 \%$ & $43 \%$ & $1 \%$ & 2.07 \\
\hline 2BYP_C & 63.5 & $2.20 \mathrm{E}-12$ & $24 \%$ & $43 \%$ & $1 \%$ & 2.07 \\
\hline 2BYP_D & 63.5 & $2.20 \mathrm{E}-12$ & $24 \%$ & $43 \%$ & $1 \%$ & 2.07 \\
\hline 2BYP_E & 63.5 & $2.20 \mathrm{E}-12$ & $24 \%$ & $43 \%$ & $1 \%$ & 2.07 \\
\hline 3PEO_A & 63.5 & $2.20 \mathrm{E}-12$ & $24 \%$ & $44 \%$ & $4 \%$ & 2.1 \\
\hline 3PEO_B & 63.5 & $2.20 \mathrm{E}-12$ & $24 \%$ & $44 \%$ & $4 \%$ & 2.1 \\
\hline 3PEO_C & 63.5 & $2.20 \mathrm{E}-12$ & $24 \%$ & $44 \%$ & $4 \%$ & 2.1 \\
\hline 3PEO_D & 63.5 & $2.20 \mathrm{E}-12$ & $24 \%$ & $44 \%$ & $4 \%$ & 2.1 \\
\hline 3PEO_E & 63.5 & $2.20 \mathrm{E}-12$ & $24 \%$ & $44 \%$ & $4 \%$ & 2.1 \\
\hline 3PEO_F & 63.5 & $2.20 \mathrm{E}-12$ & $24 \%$ & $44 \%$ & $4 \%$ & 2.1 \\
\hline 3PEO_G & 63.5 & $2.20 \mathrm{E}-12$ & $24 \%$ & $44 \%$ & $4 \%$ & 2.1 \\
\hline 3PEO_H & 63.5 & $2.20 \mathrm{E}-12$ & $24 \%$ & $44 \%$ & $4 \%$ & 2.1 \\
\hline 3PEO_I & 63.5 & $2.20 \mathrm{E}-12$ & $24 \%$ & $44 \%$ & $4 \%$ & 2.1 \\
\hline 3PEO_J & 63.5 & $2.20 \mathrm{E}-12$ & $24 \%$ & $44 \%$ & $4 \%$ & 2.1 \\
\hline 1UW6_A & 44.3 & $2.20 \mathrm{E}-05$ & $24 \%$ & $40 \%$ & $3 \%$ & 2.2 \\
\hline 1UW6_B & 44.3 & $2.20 \mathrm{E}-05$ & $24 \%$ & $40 \%$ & $3 \%$ & 2.2 \\
\hline 1UW6_C & 44.3 & $2.20 \mathrm{E}-05$ & $24 \%$ & $40 \%$ & $3 \%$ & 2.2 \\
\hline 1UW6_D & 44.3 & $2.20 \mathrm{E}-05$ & $24 \%$ & $40 \%$ & $3 \%$ & 2.2 \\
\hline 1UW6_E & 44.3 & $2.20 \mathrm{E}-05$ & $24 \%$ & $40 \%$ & $3 \%$ & 2.2 \\
\hline 1UW6_F & 44.3 & $2.20 \mathrm{E}-05$ & $24 \%$ & $40 \%$ & $3 \%$ & 2.2 \\
\hline
\end{tabular}




\section{Continued}

\begin{tabular}{|c|c|c|c|c|c|c|}
\hline 1UW6_G & 44.3 & $2.20 \mathrm{E}-05$ & $24 \%$ & $40 \%$ & $3 \%$ & 2.2 \\
\hline 1UW6_H & 44.3 & $2.20 \mathrm{E}-05$ & $24 \%$ & $40 \%$ & $3 \%$ & 2.2 \\
\hline 1UW6_I & 44.3 & $2.20 \mathrm{E}-05$ & $24 \%$ & $40 \%$ & $3 \%$ & 2.2 \\
\hline 1UW6_J & 44.3 & $2.20 \mathrm{E}-05$ & $24 \%$ & $40 \%$ & $3 \%$ & 2.2 \\
\hline 1UW6_K & 44.3 & $2.20 \mathrm{E}-05$ & $24 \%$ & $40 \%$ & $3 \%$ & 2.2 \\
\hline 1UW6_L & 44.3 & $2.20 \mathrm{E}-05$ & $24 \%$ & $40 \%$ & $3 \%$ & 2.2 \\
\hline 1UW6_M & 44.3 & $2.20 \mathrm{E}-05$ & $24 \%$ & $40 \%$ & $3 \%$ & 2.2 \\
\hline 1UW6_N & 44.3 & $2.20 \mathrm{E}-05$ & $24 \%$ & $40 \%$ & $3 \%$ & 2.2 \\
\hline 1UW6_O & 44.3 & $2.20 \mathrm{E}-05$ & $24 \%$ & $40 \%$ & $3 \%$ & 2.2 \\
\hline 1UW6_P & 44.3 & $2.20 \mathrm{E}-05$ & $24 \%$ & $40 \%$ & $3 \%$ & 2.2 \\
\hline 1UW6_Q & 44.3 & $2.20 \mathrm{E}-05$ & $24 \%$ & $40 \%$ & $3 \%$ & 2.2 \\
\hline 1UX2_A & 43.9 & $2.40 \mathrm{E}-05$ & $24 \%$ & $40 \%$ & $3 \%$ & 2.2 \\
\hline 1UX2_B & 43.9 & $2.40 \mathrm{E}-05$ & $24 \%$ & $40 \%$ & $3 \%$ & 2.2 \\
\hline 1UX2_C & 43.9 & $2.40 \mathrm{E}-05$ & $24 \%$ & $40 \%$ & $3 \%$ & 2.2 \\
\hline 1UX2_D & 43.9 & $2.40 \mathrm{E}-05$ & $24 \%$ & $40 \%$ & $3 \%$ & 2.2 \\
\hline 1UX2_E & 43.9 & $2.40 \mathrm{E}-05$ & $24 \%$ & $40 \%$ & $3 \%$ & 2.2 \\
\hline 1UX2_F & 43.9 & $2.40 \mathrm{E}-05$ & $24 \%$ & $40 \%$ & $3 \%$ & 2.2 \\
\hline 1UX2_G & 43.9 & $2.40 \mathrm{E}-05$ & $24 \%$ & $40 \%$ & $3 \%$ & 2.2 \\
\hline 1UX2_H & 43.9 & $2.40 \mathrm{E}-05$ & $24 \%$ & $40 \%$ & $3 \%$ & 2.2 \\
\hline 1UX2_I & 43.9 & $2.40 \mathrm{E}-05$ & $24 \%$ & $40 \%$ & $3 \%$ & 2.2 \\
\hline 1UX2_J & 43.9 & $2.40 \mathrm{E}-05$ & $24 \%$ & $40 \%$ & $3 \%$ & 2.2 \\
\hline 2WNC_A & 63.5 & $2.60 \mathrm{E}-12$ & $24 \%$ & $44 \%$ & $4 \%$ & 2.2 \\
\hline 2WNC_B & 63.5 & $2.60 \mathrm{E}-12$ & $24 \%$ & $44 \%$ & $4 \%$ & 2.2 \\
\hline 2WNC_C & 63.5 & $2.60 \mathrm{E}-12$ & $24 \%$ & $44 \%$ & $4 \%$ & 2.2 \\
\hline 2WNC_D & 63.5 & $2.60 \mathrm{E}-12$ & $24 \%$ & $44 \%$ & $4 \%$ & 2.2 \\
\hline 2WNC_E & 63.5 & $2.60 \mathrm{E}-12$ & $24 \%$ & $44 \%$ & $4 \%$ & 2.2 \\
\hline 4B5D_A & 70.1 & $1.30 \mathrm{E}-14$ & $28 \%$ & $46 \%$ & $8 \%$ & 2.2 \\
\hline 4B5D_B & 70.1 & $1.30 \mathrm{E}-14$ & $28 \%$ & $46 \%$ & $8 \%$ & 2.2 \\
\hline 4B5D_C & 70.1 & $1.30 \mathrm{E}-14$ & $28 \%$ & $46 \%$ & $8 \%$ & 2.2 \\
\hline 4B5D_D & 70.1 & $1.30 \mathrm{E}-14$ & $28 \%$ & $46 \%$ & $8 \%$ & 2.2 \\
\hline 4B5D_E & 70.1 & $1.30 \mathrm{E}-14$ & $28 \%$ & $46 \%$ & $8 \%$ & 2.2 \\
\hline 2C9T_A & 63.9 & $1.50 \mathrm{E}-12$ & $25 \%$ & $45 \%$ & $4 \%$ & 2.25 \\
\hline 2C9T_B & 63.9 & $1.50 \mathrm{E}-12$ & $25 \%$ & $45 \%$ & $4 \%$ & 2.25 \\
\hline 2C9T_C & 63.9 & $1.50 \mathrm{E}-12$ & $25 \%$ & $45 \%$ & $4 \%$ & 2.25 \\
\hline 2C9T_D & 63.9 & $1.50 \mathrm{E}-12$ & $25 \%$ & $45 \%$ & $4 \%$ & 2.25 \\
\hline 2C9T_E & 63.9 & $1.50 \mathrm{E}-12$ & $25 \%$ & $45 \%$ & $4 \%$ & 2.25 \\
\hline 2C9T_F & 63.9 & $1.50 \mathrm{E}-12$ & $25 \%$ & $45 \%$ & $4 \%$ & 2.25 \\
\hline
\end{tabular}




\section{Continued}

\begin{tabular}{|c|c|c|c|c|c|c|}
\hline 2C9T_G & 63.9 & $1.50 \mathrm{E}-12$ & $25 \%$ & $45 \%$ & $4 \%$ & 2.25 \\
\hline 2C9T_H & 63.9 & $1.50 \mathrm{E}-12$ & $25 \%$ & $45 \%$ & $4 \%$ & 2.25 \\
\hline 2C9T_I & 63.9 & $1.50 \mathrm{E}-12$ & $25 \%$ & $45 \%$ & $4 \%$ & 2.25 \\
\hline 2C9T_J & 63.9 & $1.50 \mathrm{E}-12$ & $25 \%$ & $45 \%$ & $4 \%$ & 2.25 \\
\hline 4ALX_A & 43.9 & $3.40 \mathrm{E}-05$ & $24 \%$ & $40 \%$ & $3 \%$ & 2.3 \\
\hline 4ALX_B & 43.9 & $3.40 \mathrm{E}-05$ & $24 \%$ & $40 \%$ & $3 \%$ & 2.3 \\
\hline 4ALX_C & 43.9 & $3.40 \mathrm{E}-05$ & $24 \%$ & $40 \%$ & $3 \%$ & 2.3 \\
\hline 4ALX_D & 43.9 & $3.40 \mathrm{E}-05$ & $24 \%$ & $40 \%$ & $3 \%$ & 2.3 \\
\hline 4ALX_E & 43.9 & $3.40 \mathrm{E}-05$ & $24 \%$ & $40 \%$ & $3 \%$ & 2.3 \\
\hline 4ALX_F & 43.9 & $3.40 \mathrm{E}-05$ & $24 \%$ & $40 \%$ & $3 \%$ & 2.3 \\
\hline 4ALX_G & 43.9 & $3.40 \mathrm{E}-05$ & $24 \%$ & $40 \%$ & $3 \%$ & 2.3 \\
\hline 4ALX_H & 43.9 & $3.40 \mathrm{E}-05$ & $24 \%$ & $40 \%$ & $3 \%$ & 2.3 \\
\hline 4ALX_I & 43.9 & $3.40 \mathrm{E}-05$ & $24 \%$ & $40 \%$ & $3 \%$ & 2.3 \\
\hline 4ALX_J & 43.9 & $3.40 \mathrm{E}-05$ & $24 \%$ & $40 \%$ & $3 \%$ & 2.3 \\
\hline 4DBM_A & 63.5 & $2.30 \mathrm{E}-12$ & $24 \%$ & $44 \%$ & $4 \%$ & 2.3 \\
\hline 4DBM_B & 63.5 & $2.30 \mathrm{E}-12$ & $24 \%$ & $44 \%$ & $4 \%$ & 2.3 \\
\hline 4DBM_C & 63.5 & $2.30 \mathrm{E}-12$ & $24 \%$ & $44 \%$ & $4 \%$ & 2.3 \\
\hline 4DBM_D & 63.5 & $2.30 \mathrm{E}-12$ & $24 \%$ & $44 \%$ & $4 \%$ & 2.3 \\
\hline 4DBM_E & 63.5 & $2.30 \mathrm{E}-12$ & $24 \%$ & $44 \%$ & $4 \%$ & 2.3 \\
\hline 3U8L_A & 44.3 & $2.20 \mathrm{E}-05$ & $24 \%$ & $40 \%$ & $3 \%$ & 2.32 \\
\hline 3U8L_B & 44.3 & $2.20 \mathrm{E}-05$ & $24 \%$ & $40 \%$ & $3 \%$ & 2.32 \\
\hline 3U8L_C & 44.3 & $2.20 \mathrm{E}-05$ & $24 \%$ & $40 \%$ & $3 \%$ & 2.32 \\
\hline 3U8L_D & 44.3 & $2.20 \mathrm{E}-05$ & $24 \%$ & $40 \%$ & $3 \%$ & 2.32 \\
\hline 3U8L_E & 44.3 & $2.20 \mathrm{E}-05$ & $24 \%$ & $40 \%$ & $3 \%$ & 2.32 \\
\hline 3U8L_F & 44.3 & $2.20 \mathrm{E}-05$ & $24 \%$ & $40 \%$ & $3 \%$ & 2.32 \\
\hline 3U8L_G & 44.3 & $2.20 \mathrm{E}-05$ & $24 \%$ & $40 \%$ & $3 \%$ & 2.32 \\
\hline 3U8L_H & 44.3 & $2.20 \mathrm{E}-05$ & $24 \%$ & $40 \%$ & $3 \%$ & 2.32 \\
\hline 3U8L_I & 44.3 & $2.20 \mathrm{E}-05$ & $24 \%$ & $40 \%$ & $3 \%$ & 2.32 \\
\hline 3U8L_J & 44.3 & $2.20 \mathrm{E}-05$ & $24 \%$ & $40 \%$ & $3 \%$ & 2.32 \\
\hline 3SIO_A & 63.5 & $3.00 \mathrm{E}-12$ & $25 \%$ & $43 \%$ & $1 \%$ & 2.32 \\
\hline 3SIO_B & 63.5 & $3.00 \mathrm{E}-12$ & $25 \%$ & $43 \%$ & $1 \%$ & 2.32 \\
\hline 3SIO_C & 63.5 & $3.00 \mathrm{E}-12$ & $25 \%$ & $43 \%$ & $1 \%$ & 2.32 \\
\hline 3SIO_D & 63.5 & $3.00 \mathrm{E}-12$ & $25 \%$ & $43 \%$ & $1 \%$ & 2.32 \\
\hline 3SIO_E & 63.5 & $3.00 \mathrm{E}-12$ & $25 \%$ & $43 \%$ & $1 \%$ & 2.32 \\
\hline 3SIO_F & 63.5 & $3.00 \mathrm{E}-12$ & $25 \%$ & $43 \%$ & $1 \%$ & 2.32 \\
\hline 3SIO_G & 63.5 & $3.00 \mathrm{E}-12$ & $25 \%$ & $43 \%$ & $1 \%$ & 2.32 \\
\hline 3SIO_H & 63.5 & $3.00 \mathrm{E}-12$ & $25 \%$ & $43 \%$ & $1 \%$ & 2.32 \\
\hline
\end{tabular}




\section{Continued}

\begin{tabular}{|c|c|c|c|c|c|c|}
\hline 3SIO_I & 63.5 & $3.00 \mathrm{E}-12$ & $25 \%$ & $43 \%$ & $1 \%$ & 2.32 \\
\hline 3SIO_J & 63.5 & $3.00 \mathrm{E}-12$ & $25 \%$ & $43 \%$ & $1 \%$ & 2.32 \\
\hline 3U8J_A & 44.3 & $2.20 \mathrm{E}-05$ & $24 \%$ & $40 \%$ & $3 \%$ & 2.35 \\
\hline 3U8J_B & 44.3 & $2.20 \mathrm{E}-05$ & $24 \%$ & $40 \%$ & $3 \%$ & 2.35 \\
\hline 3U8J_C & 44.3 & $2.20 \mathrm{E}-05$ & $24 \%$ & $40 \%$ & $3 \%$ & 2.35 \\
\hline 3U8J_D & 44.3 & $2.20 \mathrm{E}-05$ & $24 \%$ & $40 \%$ & $3 \%$ & 2.35 \\
\hline 3U8J_E & 44.3 & $2.20 \mathrm{E}-05$ & $24 \%$ & $40 \%$ & $3 \%$ & 2.35 \\
\hline 3U8J_F & 44.3 & $2.20 \mathrm{E}-05$ & $24 \%$ & $40 \%$ & $3 \%$ & 2.35 \\
\hline 3U8J_G & 44.3 & $2.20 \mathrm{E}-05$ & $24 \%$ & $40 \%$ & $3 \%$ & 2.35 \\
\hline 3U8J_H & 44.3 & $2.20 \mathrm{E}-05$ & $24 \%$ & $40 \%$ & $3 \%$ & 2.35 \\
\hline 3U8J_I & 44.3 & $2.20 \mathrm{E}-05$ & $24 \%$ & $40 \%$ & $3 \%$ & 2.35 \\
\hline 3U8J_J & 44.3 & $2.20 \mathrm{E}-05$ & $24 \%$ & $40 \%$ & $3 \%$ & 2.35 \\
\hline 3U8N_A & 44.3 & $2.20 \mathrm{E}-05$ & $24 \%$ & $40 \%$ & $3 \%$ & 2.35 \\
\hline 3U8N_B & 44.3 & $2.20 \mathrm{E}-05$ & $24 \%$ & $40 \%$ & $3 \%$ & 2.35 \\
\hline 3U8N_C & 44.3 & $2.20 \mathrm{E}-05$ & $24 \%$ & $40 \%$ & $3 \%$ & 2.35 \\
\hline 3U8N_D & 44.3 & $2.20 \mathrm{E}-05$ & $24 \%$ & $40 \%$ & $3 \%$ & 2.35 \\
\hline 3U8N_E & 44.3 & $2.20 \mathrm{E}-05$ & $24 \%$ & $40 \%$ & $3 \%$ & 2.35 \\
\hline 3U8N_F & 44.3 & $2.20 \mathrm{E}-05$ & $24 \%$ & $40 \%$ & $3 \%$ & 2.35 \\
\hline 3U8N_G & 44.3 & $2.20 \mathrm{E}-05$ & $24 \%$ & $40 \%$ & $3 \%$ & 2.35 \\
\hline 3U8N_H & 44.3 & $2.20 \mathrm{E}-05$ & $24 \%$ & $40 \%$ & $3 \%$ & 2.35 \\
\hline 3U8N_I & 44.3 & $2.20 \mathrm{E}-05$ & $24 \%$ & $40 \%$ & $3 \%$ & 2.35 \\
\hline 3U8N_J & 44.3 & $2.20 \mathrm{E}-05$ & $24 \%$ & $40 \%$ & $3 \%$ & 2.35 \\
\hline 3U8N_K & 44.3 & $2.20 \mathrm{E}-05$ & $24 \%$ & $40 \%$ & $3 \%$ & 2.35 \\
\hline 3U8N_L & 44.3 & $2.20 \mathrm{E}-05$ & $24 \%$ & $40 \%$ & $3 \%$ & 2.35 \\
\hline 3U8N_M & 44.3 & $2.20 \mathrm{E}-05$ & $24 \%$ & $40 \%$ & $3 \%$ & 2.35 \\
\hline 3U8N_N & 44.3 & $2.20 \mathrm{E}-05$ & $24 \%$ & $40 \%$ & $3 \%$ & 2.35 \\
\hline 3U8N_O & 44.3 & $2.20 \mathrm{E}-05$ & $24 \%$ & $40 \%$ & $3 \%$ & 2.35 \\
\hline 3U8N_P & 44.3 & $2.20 \mathrm{E}-05$ & $24 \%$ & $40 \%$ & $3 \%$ & 2.35 \\
\hline 3U8N_Q & 44.3 & $2.20 \mathrm{E}-05$ & $24 \%$ & $40 \%$ & $3 \%$ & 2.35 \\
\hline 3U8N_R & 44.3 & $2.20 \mathrm{E}-05$ & $24 \%$ & $40 \%$ & $3 \%$ & 2.35 \\
\hline 3U8N_S & 44.3 & $2.20 \mathrm{E}-05$ & $24 \%$ & $40 \%$ & $3 \%$ & 2.35 \\
\hline 3U8N_T & 44.3 & $2.20 \mathrm{E}-05$ & $24 \%$ & $40 \%$ & $3 \%$ & 2.35 \\
\hline 2X00_A & 63.5 & $2.20 \mathrm{E}-12$ & $24 \%$ & $44 \%$ & $4 \%$ & 2.4 \\
\hline 2X00_B & 63.5 & $2.20 \mathrm{E}-12$ & $24 \%$ & $44 \%$ & $4 \%$ & 2.4 \\
\hline 2X00_C & 63.5 & $2.20 \mathrm{E}-12$ & $24 \%$ & $44 \%$ & $4 \%$ & 2.4 \\
\hline 2X00_D & 63.5 & $2.20 \mathrm{E}-12$ & $24 \%$ & $44 \%$ & $4 \%$ & 2.4 \\
\hline 2X00_E & 63.5 & $2.20 \mathrm{E}-12$ & $24 \%$ & $44 \%$ & $4 \%$ & 2.4 \\
\hline
\end{tabular}




\section{Continued}

\begin{tabular}{|c|c|c|c|c|c|c|}
\hline 2BR8_A & 63.9 & $1.50 \mathrm{E}-12$ & $25 \%$ & $45 \%$ & $4 \%$ & 2.4 \\
\hline 2BR8_B & 63.9 & $1.50 \mathrm{E}-12$ & $25 \%$ & $45 \%$ & $4 \%$ & 2.4 \\
\hline 2BR8_C & 63.9 & $1.50 \mathrm{E}-12$ & $25 \%$ & $45 \%$ & $4 \%$ & 2.4 \\
\hline 2BR8_D & 63.9 & $1.50 \mathrm{E}-12$ & $25 \%$ & $45 \%$ & $4 \%$ & 2.4 \\
\hline 2BR8_E & 63.9 & $1.50 \mathrm{E}-12$ & $25 \%$ & $45 \%$ & $4 \%$ & 2.4 \\
\hline 2UZ6_A & 63.9 & $1.50 \mathrm{E}-12$ & $25 \%$ & $45 \%$ & $4 \%$ & 2.4 \\
\hline 2UZ6_B & 63.9 & $1.50 \mathrm{E}-12$ & $25 \%$ & $45 \%$ & $4 \%$ & 2.4 \\
\hline 2UZ6_C & 63.9 & $1.50 \mathrm{E}-12$ & $25 \%$ & $45 \%$ & $4 \%$ & 2.4 \\
\hline 2UZ6_D & 63.9 & $1.50 \mathrm{E}-12$ & $25 \%$ & $45 \%$ & $4 \%$ & 2.4 \\
\hline 2UZ6_E & 63.9 & $1.50 \mathrm{E}-12$ & $25 \%$ & $45 \%$ & $4 \%$ & 2.4 \\
\hline 2UZ6_F & 63.9 & $1.50 \mathrm{E}-12$ & $25 \%$ & $45 \%$ & $4 \%$ & 2.4 \\
\hline 2UZ6_G & 63.9 & $1.50 \mathrm{E}-12$ & $25 \%$ & $45 \%$ & $4 \%$ & 2.4 \\
\hline 2UZ6_H & 63.9 & $1.50 \mathrm{E}-12$ & $25 \%$ & $45 \%$ & $4 \%$ & 2.4 \\
\hline 2UZ6_I & 63.9 & $1.50 \mathrm{E}-12$ & $25 \%$ & $45 \%$ & $4 \%$ & 2.4 \\
\hline 2UZ6_J & 63.9 & $1.50 \mathrm{E}-12$ & $25 \%$ & $45 \%$ & $4 \%$ & 2.4 \\
\hline 2YME_A & 66.6 & $1.60 \mathrm{E}-13$ & $25 \%$ & $43 \%$ & $1 \%$ & 2.4 \\
\hline 2YME_B & 66.6 & $1.60 \mathrm{E}-13$ & $25 \%$ & $43 \%$ & $1 \%$ & 2.4 \\
\hline 2YME_C & 66.6 & $1.60 \mathrm{E}-13$ & $25 \%$ & $43 \%$ & $1 \%$ & 2.4 \\
\hline 2YME_D & 66.6 & $1.60 \mathrm{E}-13$ & $25 \%$ & $43 \%$ & $1 \%$ & 2.4 \\
\hline 2YME_E & 66.6 & $1.60 \mathrm{E}-13$ & $25 \%$ & $43 \%$ & $1 \%$ & 2.4 \\
\hline 2YME_F & 66.6 & $1.60 \mathrm{E}-13$ & $25 \%$ & $43 \%$ & $1 \%$ & 2.4 \\
\hline 2YME_G & 66.6 & $1.60 \mathrm{E}-13$ & $25 \%$ & $43 \%$ & $1 \%$ & 2.4 \\
\hline 2YME_H & 66.6 & $1.60 \mathrm{E}-13$ & $25 \%$ & $43 \%$ & $1 \%$ & 2.4 \\
\hline 2YME_I & 66.6 & $1.60 \mathrm{E}-13$ & $25 \%$ & $43 \%$ & $1 \%$ & 2.4 \\
\hline 2YME_J & 66.6 & $1.60 \mathrm{E}-13$ & $25 \%$ & $43 \%$ & $1 \%$ & 2.4 \\
\hline 2XNV_A & 63.5 & $2.80 \mathrm{E}-12$ & $24 \%$ & $44 \%$ & $4 \%$ & 2.44 \\
\hline 2XNV_B & 63.5 & $2.80 \mathrm{E}-12$ & $24 \%$ & $44 \%$ & $4 \%$ & 2.44 \\
\hline 2XNV_C & 63.5 & $2.80 \mathrm{E}-12$ & $24 \%$ & $44 \%$ & $4 \%$ & 2.44 \\
\hline 2XNV_D & 63.5 & $2.80 \mathrm{E}-12$ & $24 \%$ & $44 \%$ & $4 \%$ & 2.44 \\
\hline 2XNV_E & 63.5 & $2.80 \mathrm{E}-12$ & $24 \%$ & $44 \%$ & $4 \%$ & 2.44 \\
\hline 2XNV_F & 63.5 & $2.80 \mathrm{E}-12$ & $24 \%$ & $44 \%$ & $4 \%$ & 2.44 \\
\hline 2XNV_G & 63.5 & $2.80 \mathrm{E}-12$ & $24 \%$ & $44 \%$ & $4 \%$ & 2.44 \\
\hline 2XNV_H & 63.5 & $2.80 \mathrm{E}-12$ & $24 \%$ & $44 \%$ & $4 \%$ & 2.44 \\
\hline 2XNV_I & 63.5 & $2.80 \mathrm{E}-12$ & $24 \%$ & $44 \%$ & $4 \%$ & 2.44 \\
\hline $2 \mathrm{XNV} \_\mathrm{J}$ & 63.5 & $2.80 \mathrm{E}-12$ & $24 \%$ & $44 \%$ & $4 \%$ & 2.44 \\
\hline 3PMZ_A & 63.5 & $2.60 \mathrm{E}-12$ & $24 \%$ & $44 \%$ & $4 \%$ & 2.44 \\
\hline 3PMZ_B & 63.5 & $2.60 \mathrm{E}-12$ & $24 \%$ & $44 \%$ & $4 \%$ & 2.44 \\
\hline
\end{tabular}




\section{Continued}

\begin{tabular}{|c|c|c|c|c|c|c|}
\hline 3PMZ_C & 63.5 & $2.60 \mathrm{E}-12$ & $24 \%$ & $44 \%$ & $4 \%$ & 2.44 \\
\hline 3PMZ_D & 63.5 & $2.60 \mathrm{E}-12$ & $24 \%$ & $44 \%$ & $4 \%$ & 2.44 \\
\hline 3PMZ_E & 63.5 & $2.60 \mathrm{E}-12$ & $24 \%$ & $44 \%$ & $4 \%$ & 2.44 \\
\hline 3PMZ_F & 63.5 & $2.60 \mathrm{E}-12$ & $24 \%$ & $44 \%$ & $4 \%$ & 2.44 \\
\hline 3PMZ_G & 63.5 & $2.60 \mathrm{E}-12$ & $24 \%$ & $44 \%$ & $4 \%$ & 2.44 \\
\hline 3PMZ_H & 63.5 & $2.60 \mathrm{E}-12$ & $24 \%$ & $44 \%$ & $4 \%$ & 2.44 \\
\hline 3PMZ_I & 63.5 & $2.60 \mathrm{E}-12$ & $24 \%$ & $44 \%$ & $4 \%$ & 2.44 \\
\hline 3PMZ_J & 63.5 & $2.60 \mathrm{E}-12$ & $24 \%$ & $44 \%$ & $4 \%$ & 2.44 \\
\hline 2BYR_A & 63.5 & $2.60 \mathrm{E}-12$ & $24 \%$ & $44 \%$ & $4 \%$ & 2.45 \\
\hline 2BYR_B & 63.5 & $2.60 \mathrm{E}-12$ & $24 \%$ & $44 \%$ & $4 \%$ & 2.45 \\
\hline 2BYR_C & 63.5 & $2.60 \mathrm{E}-12$ & $24 \%$ & $44 \%$ & $4 \%$ & 2.45 \\
\hline 2BYR_D & 63.5 & $2.60 \mathrm{E}-12$ & $24 \%$ & $44 \%$ & $4 \%$ & 2.45 \\
\hline 2BYR_E & 63.5 & $2.60 \mathrm{E}-12$ & $24 \%$ & $44 \%$ & $4 \%$ & 2.45 \\
\hline 2BYR_F & 63.5 & $2.60 \mathrm{E}-12$ & $24 \%$ & $44 \%$ & $4 \%$ & 2.45 \\
\hline 2BYR_G & 63.5 & $2.60 \mathrm{E}-12$ & $24 \%$ & $44 \%$ & $4 \%$ & 2.45 \\
\hline 2BYR_H & 63.5 & $2.60 \mathrm{E}-12$ & $24 \%$ & $44 \%$ & $4 \%$ & 2.45 \\
\hline 2BYR_I & 63.5 & $2.60 \mathrm{E}-12$ & $24 \%$ & $44 \%$ & $4 \%$ & 2.45 \\
\hline 2BYR_J & 63.5 & $2.60 \mathrm{E}-12$ & $24 \%$ & $44 \%$ & $4 \%$ & 2.45 \\
\hline 3U8K_A & 44.3 & $2.20 \mathrm{E}-05$ & $24 \%$ & $40 \%$ & $3 \%$ & 2.47 \\
\hline 3U8K_B & 44.3 & $2.20 \mathrm{E}-05$ & $24 \%$ & $40 \%$ & $3 \%$ & 2.47 \\
\hline 3U8K_C & 44.3 & $2.20 \mathrm{E}-05$ & $24 \%$ & $40 \%$ & $3 \%$ & 2.47 \\
\hline 3U8K_D & 44.3 & $2.20 \mathrm{E}-05$ & $24 \%$ & $40 \%$ & $3 \%$ & 2.47 \\
\hline 3U8K_E & 44.3 & $2.20 \mathrm{E}-05$ & $24 \%$ & $40 \%$ & $3 \%$ & 2.47 \\
\hline 3U8K_F & 44.3 & $2.20 \mathrm{E}-05$ & $24 \%$ & $40 \%$ & $3 \%$ & 2.47 \\
\hline 3U8K_G & 44.3 & $2.20 \mathrm{E}-05$ & $24 \%$ & $40 \%$ & $3 \%$ & 2.47 \\
\hline 3U8K_H & 44.3 & $2.20 \mathrm{E}-05$ & $24 \%$ & $40 \%$ & $3 \%$ & 2.47 \\
\hline 3U8K_I & 44.3 & $2.20 \mathrm{E}-05$ & $24 \%$ & $40 \%$ & $3 \%$ & 2.47 \\
\hline 3U8K_J & 44.3 & $2.20 \mathrm{E}-05$ & $24 \%$ & $40 \%$ & $3 \%$ & 2.47 \\
\hline 3U8K_K & 44.3 & $2.20 \mathrm{E}-05$ & $24 \%$ & $40 \%$ & $3 \%$ & 2.47 \\
\hline 3U8K_L & 44.3 & $2.20 \mathrm{E}-05$ & $24 \%$ & $40 \%$ & $3 \%$ & 2.47 \\
\hline 3U8K_M & 44.3 & $2.20 \mathrm{E}-05$ & $24 \%$ & $40 \%$ & $3 \%$ & 2.47 \\
\hline 3U8K_N & 44.3 & $2.20 \mathrm{E}-05$ & $24 \%$ & $40 \%$ & $3 \%$ & 2.47 \\
\hline 3U8K_O & 44.3 & $2.20 \mathrm{E}-05$ & $24 \%$ & $40 \%$ & $3 \%$ & 2.47 \\
\hline 3U8K_P & 44.3 & $2.20 \mathrm{E}-05$ & $24 \%$ & $40 \%$ & $3 \%$ & 2.47 \\
\hline 3U8K_Q & 44.3 & $2.20 \mathrm{E}-05$ & $24 \%$ & $40 \%$ & $3 \%$ & 2.47 \\
\hline 3U8K_R & 44.3 & $2.20 \mathrm{E}-05$ & $24 \%$ & $40 \%$ & $3 \%$ & 2.47 \\
\hline 3U8K_S & 44.3 & $2.20 \mathrm{E}-05$ & $24 \%$ & $40 \%$ & $3 \%$ & 2.47 \\
\hline
\end{tabular}




\section{Continued}

\begin{tabular}{|c|c|c|c|c|c|c|}
\hline 3U8K_T & 44.3 & $2.20 \mathrm{E}-05$ & $24 \%$ & $40 \%$ & $3 \%$ & 2.47 \\
\hline 3C79_A & 63.5 & $2.60 \mathrm{E}-12$ & $24 \%$ & $44 \%$ & $4 \%$ & 2.48 \\
\hline 3C79_B & 63.5 & $2.60 \mathrm{E}-12$ & $24 \%$ & $44 \%$ & $4 \%$ & 2.48 \\
\hline 3C79_C & 63.5 & $2.60 \mathrm{E}-12$ & $24 \%$ & $44 \%$ & $4 \%$ & 2.48 \\
\hline 3C79_D & 63.5 & $2.60 \mathrm{E}-12$ & $24 \%$ & $44 \%$ & $4 \%$ & 2.48 \\
\hline 3C79_E & 63.5 & $2.60 \mathrm{E}-12$ & $24 \%$ & $44 \%$ & $4 \%$ & 2.48 \\
\hline 1UV6_A & 44.3 & $2.20 \mathrm{E}-05$ & $24 \%$ & $40 \%$ & $3 \%$ & 2.5 \\
\hline 1UV6_B & 44.3 & $2.20 \mathrm{E}-05$ & $24 \%$ & $40 \%$ & $3 \%$ & 2.5 \\
\hline 1UV6_C & 44.3 & $2.20 \mathrm{E}-05$ & $24 \%$ & $40 \%$ & $3 \%$ & 2.5 \\
\hline 1UV6_D & 44.3 & $2.20 \mathrm{E}-05$ & $24 \%$ & $40 \%$ & $3 \%$ & 2.5 \\
\hline 1UV6_E & 44.3 & $2.20 \mathrm{E}-05$ & $24 \%$ & $40 \%$ & $3 \%$ & 2.5 \\
\hline 1UV6_F & 44.3 & $2.20 \mathrm{E}-05$ & $24 \%$ & $40 \%$ & $3 \%$ & 2.5 \\
\hline 1UV6_G & 44.3 & $2.20 \mathrm{E}-05$ & $24 \%$ & $40 \%$ & $3 \%$ & 2.5 \\
\hline 1UV6_H & 44.3 & $2.20 \mathrm{E}-05$ & $24 \%$ & $40 \%$ & $3 \%$ & 2.5 \\
\hline 1UV6_I & 44.3 & $2.20 \mathrm{E}-05$ & $24 \%$ & $40 \%$ & $3 \%$ & 2.5 \\
\hline 1UV6_J & 44.3 & $2.20 \mathrm{E}-05$ & $24 \%$ & $40 \%$ & $3 \%$ & 2.5 \\
\hline 3C75_L & 29.6 & 1.4 & $29 \%$ & $43 \%$ & $0 \%$ & 2.5 \\
\hline 3C75_M & 29.6 & 1.4 & $29 \%$ & $43 \%$ & $0 \%$ & 2.5 \\
\hline 2WZY_A & 63.5 & $2.20 \mathrm{E}-12$ & $24 \%$ & $44 \%$ & $4 \%$ & 2.51 \\
\hline 2WZY_B & 63.5 & $2.20 \mathrm{E}-12$ & $24 \%$ & $44 \%$ & $4 \%$ & 2.51 \\
\hline 2WZY_C & 63.5 & $2.20 \mathrm{E}-12$ & $24 \%$ & $44 \%$ & $4 \%$ & 2.51 \\
\hline 2WZY_D & 63.5 & $2.20 \mathrm{E}-12$ & $24 \%$ & $44 \%$ & $4 \%$ & 2.51 \\
\hline 2WZY_E & 63.5 & $2.20 \mathrm{E}-12$ & $24 \%$ & $44 \%$ & $4 \%$ & 2.51 \\
\hline 2WZY_F & 63.5 & $2.20 \mathrm{E}-12$ & $24 \%$ & $44 \%$ & $4 \%$ & 2.51 \\
\hline 2WZY_G & 63.5 & $2.20 \mathrm{E}-12$ & $24 \%$ & $44 \%$ & $4 \%$ & 2.51 \\
\hline 2WZY_H & 63.5 & $2.20 \mathrm{E}-12$ & $24 \%$ & $44 \%$ & $4 \%$ & 2.51 \\
\hline 2WZY_I & 63.5 & $2.20 \mathrm{E}-12$ & $24 \%$ & $44 \%$ & $4 \%$ & 2.51 \\
\hline 2WZY_J & 63.5 & $2.20 \mathrm{E}-12$ & $24 \%$ & $44 \%$ & $4 \%$ & 2.51 \\
\hline 2XNU_A & 63.5 & $2.80 \mathrm{E}-12$ & $24 \%$ & $44 \%$ & $4 \%$ & 2.55 \\
\hline 2XNU_B & 63.5 & $2.80 \mathrm{E}-12$ & $24 \%$ & $44 \%$ & $4 \%$ & 2.55 \\
\hline 2XNU_C & 63.5 & $2.80 \mathrm{E}-12$ & $24 \%$ & $44 \%$ & $4 \%$ & 2.55 \\
\hline 2XNU_D & 63.5 & $2.80 \mathrm{E}-12$ & $24 \%$ & $44 \%$ & $4 \%$ & 2.55 \\
\hline 2XNU_E & 63.5 & $2.80 \mathrm{E}-12$ & $24 \%$ & $44 \%$ & $4 \%$ & 2.55 \\
\hline 2ZJU_A & 43.9 & $2.90 \mathrm{E}-05$ & $24 \%$ & $41 \%$ & $3 \%$ & 2.58 \\
\hline 2ZJU_B & 43.9 & $2.90 \mathrm{E}-05$ & $24 \%$ & $41 \%$ & $3 \%$ & 2.58 \\
\hline 2ZJU_C & 43.9 & $2.90 \mathrm{E}-05$ & $24 \%$ & $41 \%$ & $3 \%$ & 2.58 \\
\hline 2ZJU_D & 43.9 & $2.90 \mathrm{E}-05$ & $24 \%$ & $41 \%$ & $3 \%$ & 2.58 \\
\hline
\end{tabular}




\section{Continued}

\begin{tabular}{|c|c|c|c|c|c|c|}
\hline 2ZJU_E & 43.9 & $2.90 \mathrm{E}-05$ & $24 \%$ & $41 \%$ & $3 \%$ & 2.58 \\
\hline 3TLW_A & 40 & 0.00074 & $24 \%$ & $42 \%$ & $7 \%$ & 2.6 \\
\hline 3TLW_B & 40 & 0.00074 & $24 \%$ & $42 \%$ & $7 \%$ & 2.6 \\
\hline 3TLW_C & 40 & 0.00074 & $24 \%$ & $42 \%$ & $7 \%$ & 2.6 \\
\hline 3TLW_D & 40 & 0.00074 & $24 \%$ & $42 \%$ & $7 \%$ & 2.6 \\
\hline 3TLW_E & 40 & 0.00074 & $24 \%$ & $42 \%$ & $7 \%$ & 2.6 \\
\hline 2W8G_A & 63.9 & $1.50 \mathrm{E}-12$ & $25 \%$ & $45 \%$ & $4 \%$ & 2.6 \\
\hline 2W8G_B & 63.9 & $1.50 \mathrm{E}-12$ & $25 \%$ & $45 \%$ & $4 \%$ & 2.6 \\
\hline 2W8G_C & 63.9 & $1.50 \mathrm{E}-12$ & $25 \%$ & $45 \%$ & $4 \%$ & 2.6 \\
\hline 2W8G_D & 63.9 & $1.50 \mathrm{E}-12$ & $25 \%$ & $45 \%$ & $4 \%$ & 2.6 \\
\hline 2W8G_E & 63.9 & $1.50 \mathrm{E}-12$ & $25 \%$ & $45 \%$ & $4 \%$ & 2.6 \\
\hline 1I9B_A & 43.9 & $2.70 \mathrm{E}-05$ & $24 \%$ & $40 \%$ & $3 \%$ & 2.7 \\
\hline 119B_B & 43.9 & $2.70 \mathrm{E}-05$ & $24 \%$ & $40 \%$ & $3 \%$ & 2.7 \\
\hline 119B_C & 43.9 & $2.70 \mathrm{E}-05$ & $24 \%$ & $40 \%$ & $3 \%$ & 2.7 \\
\hline 1I9B_D & 43.9 & $2.70 \mathrm{E}-05$ & $24 \%$ & $40 \%$ & $3 \%$ & 2.7 \\
\hline 119B_E & 43.9 & $2.70 \mathrm{E}-05$ & $24 \%$ & $40 \%$ & $3 \%$ & 2.7 \\
\hline 2WNL_A & 63.5 & $2.60 \mathrm{E}-12$ & $24 \%$ & $44 \%$ & $4 \%$ & 2.7 \\
\hline 2WNL_B & 63.5 & $2.60 \mathrm{E}-12$ & $24 \%$ & $44 \%$ & $4 \%$ & 2.7 \\
\hline 2WNL_C & 63.5 & $2.60 \mathrm{E}-12$ & $24 \%$ & $44 \%$ & $4 \%$ & 2.7 \\
\hline 2WNL_D & 63.5 & $2.60 \mathrm{E}-12$ & $24 \%$ & $44 \%$ & $4 \%$ & 2.7 \\
\hline 2WNL_E & 63.5 & $2.60 \mathrm{E}-12$ & $24 \%$ & $44 \%$ & $4 \%$ & 2.7 \\
\hline 2WNL_F & 63.5 & $2.60 \mathrm{E}-12$ & $24 \%$ & $44 \%$ & $4 \%$ & 2.7 \\
\hline 2WNL_G & 63.5 & $2.60 \mathrm{E}-12$ & $24 \%$ & $44 \%$ & $4 \%$ & 2.7 \\
\hline 2WNL_H & 63.5 & $2.60 \mathrm{E}-12$ & $24 \%$ & $44 \%$ & $4 \%$ & 2.7 \\
\hline 2WNL_I & 63.5 & $2.60 \mathrm{E}-12$ & $24 \%$ & $44 \%$ & $4 \%$ & 2.7 \\
\hline 2WNL_J & 63.5 & $2.60 \mathrm{E}-12$ & $24 \%$ & $44 \%$ & $4 \%$ & 2.7 \\
\hline 2ZJV_A & 43.9 & $2.90 \mathrm{E}-05$ & $24 \%$ & $41 \%$ & $3 \%$ & 2.7 \\
\hline 2ZJV_B & 43.9 & $2.90 \mathrm{E}-05$ & $24 \%$ & $41 \%$ & $3 \%$ & 2.7 \\
\hline 2ZJV_C & 43.9 & $2.90 \mathrm{E}-05$ & $24 \%$ & $41 \%$ & $3 \%$ & 2.7 \\
\hline 2ZJV_D & 43.9 & $2.90 \mathrm{E}-05$ & $24 \%$ & $41 \%$ & $3 \%$ & 2.7 \\
\hline 2ZJV_E & 43.9 & $2.90 \mathrm{E}-05$ & $24 \%$ & $41 \%$ & $3 \%$ & 2.7 \\
\hline 3U8M_A & 44.3 & $2.20 \mathrm{E}-05$ & $24 \%$ & $40 \%$ & $3 \%$ & 2.7 \\
\hline 3U8M_B & 44.3 & $2.20 \mathrm{E}-05$ & $24 \%$ & $40 \%$ & $3 \%$ & 2.7 \\
\hline 3U8M_C & 44.3 & $2.20 \mathrm{E}-05$ & $24 \%$ & $40 \%$ & $3 \%$ & 2.7 \\
\hline 3U8M_D & 44.3 & $2.20 \mathrm{E}-05$ & $24 \%$ & $40 \%$ & $3 \%$ & 2.7 \\
\hline 3U8M_E & 44.3 & $2.20 \mathrm{E}-05$ & $24 \%$ & $40 \%$ & $3 \%$ & 2.7 \\
\hline 3U8M_F & 44.3 & $2.20 \mathrm{E}-05$ & $24 \%$ & $40 \%$ & $3 \%$ & 2.7 \\
\hline
\end{tabular}




\section{Continued}

\begin{tabular}{|c|c|c|c|c|c|c|}
\hline 3U8M_G & 44.3 & $2.20 \mathrm{E}-05$ & $24 \%$ & $40 \%$ & $3 \%$ & 2.7 \\
\hline 3U8M_H & 44.3 & $2.20 \mathrm{E}-05$ & $24 \%$ & $40 \%$ & $3 \%$ & 2.7 \\
\hline 3U8M_I & 44.3 & $2.20 \mathrm{E}-05$ & $24 \%$ & $40 \%$ & $3 \%$ & 2.7 \\
\hline 3U8M_J & 44.3 & $2.20 \mathrm{E}-05$ & $24 \%$ & $40 \%$ & $3 \%$ & 2.7 \\
\hline 3U8M_K & 44.3 & $2.20 \mathrm{E}-05$ & $24 \%$ & $40 \%$ & $3 \%$ & 2.7 \\
\hline 3U8M_L & 44.3 & $2.20 \mathrm{E}-05$ & $24 \%$ & $40 \%$ & $3 \%$ & 2.7 \\
\hline 3U8M_M & 44.3 & $2.20 \mathrm{E}-05$ & $24 \%$ & $40 \%$ & $3 \%$ & 2.7 \\
\hline 3U8M_N & 44.3 & $2.20 \mathrm{E}-05$ & $24 \%$ & $40 \%$ & $3 \%$ & 2.7 \\
\hline 3U8M_O & 44.3 & $2.20 \mathrm{E}-05$ & $24 \%$ & $40 \%$ & $3 \%$ & 2.7 \\
\hline 3U8M_P & 44.3 & $2.20 \mathrm{E}-05$ & $24 \%$ & $40 \%$ & $3 \%$ & 2.7 \\
\hline 3U8M_Q & 44.3 & $2.20 \mathrm{E}-05$ & $24 \%$ & $40 \%$ & $3 \%$ & 2.7 \\
\hline 3U8M_R & 44.3 & $2.20 \mathrm{E}-05$ & $24 \%$ & $40 \%$ & $3 \%$ & 2.7 \\
\hline 3U8M_S & 44.3 & $2.20 \mathrm{E}-05$ & $24 \%$ & $40 \%$ & $3 \%$ & 2.7 \\
\hline 3U8M_T & 44.3 & $2.20 \mathrm{E}-05$ & $24 \%$ & $40 \%$ & $3 \%$ & 2.7 \\
\hline 2W8F_A & 63.9 & $1.50 \mathrm{E}-12$ & $25 \%$ & $45 \%$ & $4 \%$ & 2.7 \\
\hline 2W8F_B & 63.9 & $1.50 \mathrm{E}-12$ & $25 \%$ & $45 \%$ & $4 \%$ & 2.7 \\
\hline 2W8F_C & 63.9 & $1.50 \mathrm{E}-12$ & $25 \%$ & $45 \%$ & $4 \%$ & 2.7 \\
\hline 2W8F_D & 63.9 & $1.50 \mathrm{E}-12$ & $25 \%$ & $45 \%$ & $4 \%$ & 2.7 \\
\hline 2W8F_E & 63.9 & $1.50 \mathrm{E}-12$ & $25 \%$ & $45 \%$ & $4 \%$ & 2.7 \\
\hline 2W8F_F & 63.9 & $1.50 \mathrm{E}-12$ & $25 \%$ & $45 \%$ & $4 \%$ & 2.7 \\
\hline 2W8F_G & 63.9 & $1.50 \mathrm{E}-12$ & $25 \%$ & $45 \%$ & $4 \%$ & 2.7 \\
\hline 2W8F_H & 63.9 & $1.50 \mathrm{E}-12$ & $25 \%$ & $45 \%$ & $4 \%$ & 2.7 \\
\hline 2W8F_I & 63.9 & $1.50 \mathrm{E}-12$ & $25 \%$ & $45 \%$ & $4 \%$ & 2.7 \\
\hline 2W8F_J & 63.9 & $1.50 \mathrm{E}-12$ & $25 \%$ & $45 \%$ & $4 \%$ & 2.7 \\
\hline 2XZ5_A & 62.4 & $5.50 \mathrm{E}-12$ & $25 \%$ & $44 \%$ & $4 \%$ & 2.8 \\
\hline 2XZ5_B & 62.4 & $5.50 \mathrm{E}-12$ & $25 \%$ & $44 \%$ & $4 \%$ & 2.8 \\
\hline 2XZ5_C & 62.4 & $5.50 \mathrm{E}-12$ & $25 \%$ & $44 \%$ & $4 \%$ & 2.8 \\
\hline 2XZ5_D & 62.4 & $5.50 \mathrm{E}-12$ & $25 \%$ & $44 \%$ & $4 \%$ & 2.8 \\
\hline 2XZ5_E & 62.4 & $5.50 \mathrm{E}-12$ & $25 \%$ & $44 \%$ & $4 \%$ & 2.8 \\
\hline 3SQ6_A & 85.1 & $6.50 \mathrm{E}-20$ & $28 \%$ & $48 \%$ & $4 \%$ & 2.8 \\
\hline 3SQ6_B & 85.1 & $6.50 \mathrm{E}-20$ & $28 \%$ & $48 \%$ & $4 \%$ & 2.8 \\
\hline 3SQ6_C & 85.1 & $6.50 \mathrm{E}-20$ & $28 \%$ & $48 \%$ & $4 \%$ & 2.8 \\
\hline 3SQ6_D & 85.1 & $6.50 \mathrm{E}-20$ & $28 \%$ & $48 \%$ & $4 \%$ & 2.8 \\
\hline 3SQ6_E & 85.1 & $6.50 \mathrm{E}-20$ & $28 \%$ & $48 \%$ & $4 \%$ & 2.8 \\
\hline 3SQ6_F & 85.1 & $6.50 \mathrm{E}-20$ & $28 \%$ & $48 \%$ & $4 \%$ & 2.8 \\
\hline 3SQ6_G & 85.1 & $6.50 \mathrm{E}-20$ & $28 \%$ & $48 \%$ & $4 \%$ & 2.8 \\
\hline 3SQ6_H & 85.1 & $6.50 \mathrm{E}-20$ & $28 \%$ & $48 \%$ & $4 \%$ & 2.8 \\
\hline
\end{tabular}




\section{Continued}

\begin{tabular}{|c|c|c|c|c|c|c|}
\hline 3SQ6_I & 85.1 & $6.50 \mathrm{E}-20$ & $28 \%$ & $48 \%$ & $4 \%$ & 2.8 \\
\hline 3SQ6_J & 85.1 & $6.50 \mathrm{E}-20$ & $28 \%$ & $48 \%$ & $4 \%$ & 2.8 \\
\hline 3TLU_A & 40 & 0.00074 & $24 \%$ & $42 \%$ & $7 \%$ & 2.85 \\
\hline 3TLU_B & 40 & 0.00074 & $24 \%$ & $42 \%$ & $7 \%$ & 2.85 \\
\hline 3TLU_C & 40 & 0.00074 & $24 \%$ & $42 \%$ & $7 \%$ & 2.85 \\
\hline 3TLU_D & 40 & 0.00074 & $24 \%$ & $42 \%$ & $7 \%$ & 2.85 \\
\hline 3TLU_E & 40 & 0.00074 & $24 \%$ & $42 \%$ & $7 \%$ & 2.85 \\
\hline 2PH9_A & 63.5 & $2.30 \mathrm{E}-12$ & $24 \%$ & $44 \%$ & $4 \%$ & 2.88 \\
\hline 2PH9_B & 63.5 & $2.30 \mathrm{E}-12$ & $24 \%$ & $44 \%$ & $4 \%$ & 2.88 \\
\hline 2PH9_C & 63.5 & $2.30 \mathrm{E}-12$ & $24 \%$ & $44 \%$ & $4 \%$ & 2.88 \\
\hline 2PH9_D & 63.5 & $2.30 \mathrm{E}-12$ & $24 \%$ & $44 \%$ & $4 \%$ & 2.88 \\
\hline 2PH9_E & 63.5 & $2.30 \mathrm{E}-12$ & $24 \%$ & $44 \%$ & $4 \%$ & 2.88 \\
\hline 3EAM_A & 42.7 & $9.30 \mathrm{E}-05$ & $24 \%$ & $43 \%$ & $7 \%$ & 2.9 \\
\hline 3EAM_B & 42.7 & $9.30 \mathrm{E}-05$ & $24 \%$ & $43 \%$ & $7 \%$ & 2.9 \\
\hline 3EAM_C & 42.7 & $9.30 \mathrm{E}-05$ & $24 \%$ & $43 \%$ & $7 \%$ & 2.9 \\
\hline 3EAM_D & 42.7 & $9.30 \mathrm{E}-05$ & $24 \%$ & $43 \%$ & $7 \%$ & 2.9 \\
\hline 3EAM_E & 42.7 & $9.30 \mathrm{E}-05$ & $24 \%$ & $43 \%$ & $7 \%$ & 2.9 \\
\hline 3TLV_A & 40 & 0.00068 & $24 \%$ & $42 \%$ & $7 \%$ & 2.9 \\
\hline 3TLV_B & 40 & 0.00068 & $24 \%$ & $42 \%$ & $7 \%$ & 2.9 \\
\hline 3TLV_C & 40 & 0.00068 & $24 \%$ & $42 \%$ & $7 \%$ & 2.9 \\
\hline 3TLV_D & 40 & 0.00068 & $24 \%$ & $42 \%$ & $7 \%$ & 2.9 \\
\hline 3TLV_E & 40 & 0.00068 & $24 \%$ & $42 \%$ & $7 \%$ & 2.9 \\
\hline 3UU5_A & 40 & 0.0007 & $24 \%$ & $42 \%$ & $7 \%$ & 2.9 \\
\hline 3UU5_B & 40 & 0.0007 & $24 \%$ & $42 \%$ & $7 \%$ & 2.9 \\
\hline 3UU5_C & 40 & 0.0007 & $24 \%$ & $42 \%$ & $7 \%$ & 2.9 \\
\hline 3UU5_D & 40 & 0.0007 & $24 \%$ & $42 \%$ & $7 \%$ & 2.9 \\
\hline 3UU5_E & 40 & 0.0007 & $24 \%$ & $42 \%$ & $7 \%$ & 2.9 \\
\hline 3UUB_A & 40 & 0.00074 & $24 \%$ & $42 \%$ & $7 \%$ & 2.9 \\
\hline 3UUB_B & 40 & 0.00074 & $24 \%$ & $42 \%$ & $7 \%$ & 2.9 \\
\hline 3UUB_C & 40 & 0.00074 & $24 \%$ & $42 \%$ & $7 \%$ & 2.9 \\
\hline 3UUB_D & 40 & 0.00074 & $24 \%$ & $42 \%$ & $7 \%$ & 2.9 \\
\hline 3UUB_E & 40 & 0.00074 & $24 \%$ & $42 \%$ & $7 \%$ & 2.9 \\
\hline 3UUB_F & 40 & 0.00074 & $24 \%$ & $42 \%$ & $7 \%$ & 2.9 \\
\hline 3UUB_G & 40 & 0.00074 & $24 \%$ & $42 \%$ & $7 \%$ & 2.9 \\
\hline 3UUB_H & 40 & 0.00074 & $24 \%$ & $42 \%$ & $7 \%$ & 2.9 \\
\hline 3UUB_I & 40 & 0.00074 & $24 \%$ & $42 \%$ & $7 \%$ & 2.9 \\
\hline 3UUB_J & 40 & 0.00074 & $24 \%$ & $42 \%$ & $7 \%$ & 2.9 \\
\hline
\end{tabular}




\section{Continued}

\begin{tabular}{|c|c|c|c|c|c|c|}
\hline 3SH1_A & 65.5 & $4.80 \mathrm{E}-13$ & $25 \%$ & $43 \%$ & $1 \%$ & 2.9 \\
\hline 3SH1_B & 65.5 & $4.80 \mathrm{E}-13$ & $25 \%$ & $43 \%$ & $1 \%$ & 2.9 \\
\hline 3SH1_C & 65.5 & $4.80 \mathrm{E}-13$ & $25 \%$ & $43 \%$ & $1 \%$ & 2.9 \\
\hline 3SH1_D & 65.5 & $4.80 \mathrm{E}-13$ & $25 \%$ & $43 \%$ & $1 \%$ & 2.9 \\
\hline 3SH1_E & 65.5 & $4.80 \mathrm{E}-13$ & $25 \%$ & $43 \%$ & $1 \%$ & 2.9 \\
\hline 3SH1_F & 65.5 & $4.80 \mathrm{E}-13$ & $25 \%$ & $43 \%$ & $1 \%$ & 2.9 \\
\hline 3SH1_G & 65.5 & $4.80 \mathrm{E}-13$ & $25 \%$ & $43 \%$ & $1 \%$ & 2.9 \\
\hline 3SH1_H & 65.5 & $4.80 \mathrm{E}-13$ & $25 \%$ & $43 \%$ & $1 \%$ & 2.9 \\
\hline 3SH1_I & 65.5 & $4.80 \mathrm{E}-13$ & $25 \%$ & $43 \%$ & $1 \%$ & 2.9 \\
\hline 3SH1_J & 65.5 & $4.80 \mathrm{E}-13$ & $25 \%$ & $43 \%$ & $1 \%$ & 2.9 \\
\hline 3RQW_A & 27.3 & 9 & $18 \%$ & $42 \%$ & $10 \%$ & 2.91 \\
\hline 3RQW_B & 27.3 & 9 & $18 \%$ & $42 \%$ & $10 \%$ & 2.91 \\
\hline 3RQW_C & 27.3 & 9 & $18 \%$ & $42 \%$ & $10 \%$ & 2.91 \\
\hline 3RQW_D & 27.3 & 9 & $18 \%$ & $42 \%$ & $10 \%$ & 2.91 \\
\hline 3RQW_E & 27.3 & 9 & $18 \%$ & $42 \%$ & $10 \%$ & 2.91 \\
\hline 3RQW_F & 27.3 & 9 & $18 \%$ & $42 \%$ & $10 \%$ & 2.91 \\
\hline 3RQW_G & 27.3 & 9 & $18 \%$ & $42 \%$ & $10 \%$ & 2.91 \\
\hline 3RQW_H & 27.3 & 9 & $18 \%$ & $42 \%$ & $10 \%$ & 2.91 \\
\hline 3RQW_I & 27.3 & 9 & $18 \%$ & $42 \%$ & $10 \%$ & 2.91 \\
\hline 3RQW_J & 27.3 & 9 & $18 \%$ & $42 \%$ & $10 \%$ & 2.91 \\
\hline 3UU6_A & 40 & 0.00068 & $24 \%$ & $42 \%$ & $7 \%$ & 2.98 \\
\hline 3UU6_B & 40 & 0.00068 & $24 \%$ & $42 \%$ & $7 \%$ & 2.98 \\
\hline 3UU6_C & 40 & 0.00068 & $24 \%$ & $42 \%$ & $7 \%$ & 2.98 \\
\hline 3UU6_D & 40 & 0.00068 & $24 \%$ & $42 \%$ & $7 \%$ & 2.98 \\
\hline 3UU6_E & 40 & 0.00068 & $24 \%$ & $42 \%$ & $7 \%$ & 2.98 \\
\hline 4F8H_A & 42.7 & $8.70 \mathrm{E}-05$ & $24 \%$ & $43 \%$ & $7 \%$ & 2.99 \\
\hline 4F8H_B & 42.7 & $8.70 \mathrm{E}-05$ & $24 \%$ & $43 \%$ & $7 \%$ & 2.99 \\
\hline 4F8H_C & 42.7 & $8.70 \mathrm{E}-05$ & $24 \%$ & $43 \%$ & $7 \%$ & 2.99 \\
\hline 4F8H_D & 42.7 & $8.70 \mathrm{E}-05$ & $24 \%$ & $43 \%$ & $7 \%$ & 2.99 \\
\hline 4F8H_E & 42.7 & $8.70 \mathrm{E}-05$ & $24 \%$ & $43 \%$ & $7 \%$ & 2.99 \\
\hline 2BR7_A & 63.9 & $1.50 \mathrm{E}-12$ & $25 \%$ & $45 \%$ & $4 \%$ & 3 \\
\hline 2BR7_B & 63.9 & $1.50 \mathrm{E}-12$ & $25 \%$ & $45 \%$ & $4 \%$ & 3 \\
\hline 2BR7_C & 63.9 & $1.50 \mathrm{E}-12$ & $25 \%$ & $45 \%$ & $4 \%$ & 3 \\
\hline 2BR7_D & 63.9 & $1.50 \mathrm{E}-12$ & $25 \%$ & $45 \%$ & $4 \%$ & 3 \\
\hline 2BR7_E & 63.9 & $1.50 \mathrm{E}-12$ & $25 \%$ & $45 \%$ & $4 \%$ & 3 \\
\hline 3T4M_A & 69.7 & $2.00 \mathrm{E}-14$ & $26 \%$ & $44 \%$ & $1 \%$ & 3 \\
\hline 3T4M_B & 69.7 & $2.00 \mathrm{E}-14$ & $26 \%$ & $44 \%$ & $1 \%$ & 3 \\
\hline
\end{tabular}




\section{Continued}

\begin{tabular}{|c|c|c|c|c|c|c|}
\hline 3T4M_C & 69.7 & $2.00 \mathrm{E}-14$ & $26 \%$ & $44 \%$ & $1 \%$ & 3 \\
\hline 3T4M_D & 69.7 & $2.00 \mathrm{E}-14$ & $26 \%$ & $44 \%$ & $1 \%$ & 3 \\
\hline 3T4M_E & 69.7 & $2.00 \mathrm{E}-14$ & $26 \%$ & $44 \%$ & $1 \%$ & 3 \\
\hline 3T4M_F & 69.7 & $2.00 \mathrm{E}-14$ & $26 \%$ & $44 \%$ & $1 \%$ & 3 \\
\hline 3T4M_G & 69.7 & $2.00 \mathrm{E}-14$ & $26 \%$ & $44 \%$ & $1 \%$ & 3 \\
\hline 3T4M_H & 69.7 & $2.00 \mathrm{E}-14$ & $26 \%$ & $44 \%$ & $1 \%$ & 3 \\
\hline 3T4M_I & 69.7 & $2.00 \mathrm{E}-14$ & $26 \%$ & $44 \%$ & $1 \%$ & 3 \\
\hline 3T4M_J & 69.7 & $2.00 \mathrm{E}-14$ & $26 \%$ & $44 \%$ & $1 \%$ & 3 \\
\hline 1LDJ_A & 28.1 & 7.2 & $29 \%$ & $50 \%$ & $15 \%$ & 3 \\
\hline 3UU4_A & 40 & 0.00074 & $24 \%$ & $42 \%$ & $7 \%$ & 3.05 \\
\hline 3UU4_B & 40 & 0.00074 & $24 \%$ & $42 \%$ & $7 \%$ & 3.05 \\
\hline 3UU4_C & 40 & 0.00074 & $24 \%$ & $42 \%$ & $7 \%$ & 3.05 \\
\hline 3UU4_D & 40 & 0.00074 & $24 \%$ & $42 \%$ & $7 \%$ & 3.05 \\
\hline 3UU4_E & 40 & 0.00074 & $24 \%$ & $42 \%$ & $7 \%$ & 3.05 \\
\hline 3RQU_A & 27.3 & 9 & $18 \%$ & $42 \%$ & $10 \%$ & 3.09 \\
\hline 3RQU_B & 27.3 & 9 & $18 \%$ & $42 \%$ & $10 \%$ & 3.09 \\
\hline 3RQU_C & 27.3 & 9 & $18 \%$ & $42 \%$ & $10 \%$ & 3.09 \\
\hline 3RQU_D & 27.3 & 9 & $18 \%$ & $42 \%$ & $10 \%$ & 3.09 \\
\hline 3RQU_E & 27.3 & 9 & $18 \%$ & $42 \%$ & $10 \%$ & 3.09 \\
\hline 3RQU_F & 27.3 & 9 & $18 \%$ & $42 \%$ & $10 \%$ & 3.09 \\
\hline 3RQU_G & 27.3 & 9 & $18 \%$ & $42 \%$ & $10 \%$ & 3.09 \\
\hline 3RQU_H & 27.3 & 9 & $18 \%$ & $42 \%$ & $10 \%$ & 3.09 \\
\hline 3RQU_I & 27.3 & 9 & $18 \%$ & $42 \%$ & $10 \%$ & 3.09 \\
\hline 3RQU_J & 27.3 & 9 & $18 \%$ & $42 \%$ & $10 \%$ & 3.09 \\
\hline 3EHZ_A & 42.7 & $8.70 \mathrm{E}-05$ & $24 \%$ & $43 \%$ & $7 \%$ & 3.1 \\
\hline 3EHZ_B & 42.7 & $8.70 \mathrm{E}-05$ & $24 \%$ & $43 \%$ & $7 \%$ & 3.1 \\
\hline 3EHZ_C & 42.7 & $8.70 \mathrm{E}-05$ & $24 \%$ & $43 \%$ & $7 \%$ & 3.1 \\
\hline 3EHZ_D & 42.7 & $8.70 \mathrm{E}-05$ & $24 \%$ & $43 \%$ & $7 \%$ & 3.1 \\
\hline 3EHZ_E & 42.7 & $8.70 \mathrm{E}-05$ & $24 \%$ & $43 \%$ & $7 \%$ & 3.1 \\
\hline 3GUA_A & 63.5 & $2.30 \mathrm{E}-12$ & $24 \%$ & $43 \%$ & $1 \%$ & 3.1 \\
\hline 3GUA_B & 63.5 & $2.30 \mathrm{E}-12$ & $24 \%$ & $43 \%$ & $1 \%$ & 3.1 \\
\hline 3GUA_C & 63.5 & $2.30 \mathrm{E}-12$ & $24 \%$ & $43 \%$ & $1 \%$ & 3.1 \\
\hline 3GUA_D & 63.5 & $2.30 \mathrm{E}-12$ & $24 \%$ & $43 \%$ & $1 \%$ & 3.1 \\
\hline 3GUA_E & 63.5 & $2.30 \mathrm{E}-12$ & $24 \%$ & $43 \%$ & $1 \%$ & 3.1 \\
\hline 3GUA_F & 63.5 & $2.30 \mathrm{E}-12$ & $24 \%$ & $43 \%$ & $1 \%$ & 3.1 \\
\hline 3GUA_G & 63.5 & $2.30 \mathrm{E}-12$ & $24 \%$ & $43 \%$ & $1 \%$ & 3.1 \\
\hline 3GUA_H & 63.5 & $2.30 \mathrm{E}-12$ & $24 \%$ & $43 \%$ & $1 \%$ & 3.1 \\
\hline
\end{tabular}




\section{Continued}

\begin{tabular}{|c|c|c|c|c|c|c|}
\hline 3GUA_I & 63.5 & $2.30 \mathrm{E}-12$ & $24 \%$ & $43 \%$ & $1 \%$ & 3.1 \\
\hline 3GUA_J & 63.5 & $2.30 \mathrm{E}-12$ & $24 \%$ & $43 \%$ & $1 \%$ & 3.1 \\
\hline 3SQ9_A & 85.1 & $6.50 \mathrm{E}-20$ & $28 \%$ & $48 \%$ & $4 \%$ & 3.1 \\
\hline 3SQ9_B & 85.1 & $6.50 \mathrm{E}-20$ & $28 \%$ & $48 \%$ & $4 \%$ & 3.1 \\
\hline 3SQ9_C & 85.1 & $6.50 \mathrm{E}-20$ & $28 \%$ & $48 \%$ & $4 \%$ & 3.1 \\
\hline 3SQ9_D & 85.1 & $6.50 \mathrm{E}-20$ & $28 \%$ & $48 \%$ & $4 \%$ & 3.1 \\
\hline 3SQ9_E & 85.1 & $6.50 \mathrm{E}-20$ & $28 \%$ & $48 \%$ & $4 \%$ & 3.1 \\
\hline 3SQ9_F & 85.1 & $6.50 \mathrm{E}-20$ & $28 \%$ & $48 \%$ & $4 \%$ & 3.1 \\
\hline 3SQ9_G & 85.1 & $6.50 \mathrm{E}-20$ & $28 \%$ & $48 \%$ & $4 \%$ & 3.1 \\
\hline 3SQ9_H & 85.1 & $6.50 \mathrm{E}-20$ & $28 \%$ & $48 \%$ & $4 \%$ & 3.1 \\
\hline 3SQ9_I & 85.1 & $6.50 \mathrm{E}-20$ & $28 \%$ & $48 \%$ & $4 \%$ & 3.1 \\
\hline 3SQ9_J & 85.1 & $6.50 \mathrm{E}-20$ & $28 \%$ & $48 \%$ & $4 \%$ & 3.1 \\
\hline 1LDK_A & 28.5 & 4.9 & $29 \%$ & $50 \%$ & $15 \%$ & 3.1 \\
\hline 1U6G_A & 28.1 & 7.2 & $29 \%$ & $50 \%$ & $15 \%$ & 3.1 \\
\hline 2XZ6_A & 62.8 & $4.70 \mathrm{E}-12$ & $25 \%$ & $44 \%$ & $4 \%$ & 3.137 \\
\hline 2XZ6_B & 62.8 & $4.70 \mathrm{E}-12$ & $25 \%$ & $44 \%$ & $4 \%$ & 3.137 \\
\hline 2XZ6_C & 62.8 & $4.70 \mathrm{E}-12$ & $25 \%$ & $44 \%$ & $4 \%$ & 3.137 \\
\hline 2XZ6_D & 62.8 & $4.70 \mathrm{E}-12$ & $25 \%$ & $44 \%$ & $4 \%$ & 3.137 \\
\hline 2XZ6_E & 62.8 & $4.70 \mathrm{E}-12$ & $25 \%$ & $44 \%$ & $4 \%$ & 3.137 \\
\hline 2XZ6_F & 62.8 & $4.70 \mathrm{E}-12$ & $25 \%$ & $44 \%$ & $4 \%$ & 3.137 \\
\hline 2XZ6_G & 62.8 & $4.70 \mathrm{E}-12$ & $25 \%$ & $44 \%$ & $4 \%$ & 3.137 \\
\hline 2XZ6_H & 62.8 & $4.70 \mathrm{E}-12$ & $25 \%$ & $44 \%$ & $4 \%$ & 3.137 \\
\hline 2XZ6_I & 62.8 & $4.70 \mathrm{E}-12$ & $25 \%$ & $44 \%$ & $4 \%$ & 3.137 \\
\hline 2XZ6_J & 62.8 & $4.70 \mathrm{E}-12$ & $25 \%$ & $44 \%$ & $4 \%$ & 3.137 \\
\hline 3LSV_A & 42.7 & $9.60 \mathrm{E}-05$ & $24 \%$ & $43 \%$ & $7 \%$ & 3.15 \\
\hline 3LSV_B & 42.7 & $9.60 \mathrm{E}-05$ & $24 \%$ & $43 \%$ & $7 \%$ & 3.15 \\
\hline 3LSV_C & 42.7 & $9.60 \mathrm{E}-05$ & $24 \%$ & $43 \%$ & $7 \%$ & 3.15 \\
\hline 3LSV_D & 42.7 & $9.60 \mathrm{E}-05$ & $24 \%$ & $43 \%$ & $7 \%$ & 3.15 \\
\hline 3LSV_E & 42.7 & $9.60 \mathrm{E}-05$ & $24 \%$ & $43 \%$ & $7 \%$ & 3.15 \\
\hline 3UU3_A & 40 & 0.0007 & $24 \%$ & $42 \%$ & $7 \%$ & 3.15 \\
\hline 3UU3_B & 40 & 0.0007 & $24 \%$ & $42 \%$ & $7 \%$ & 3.15 \\
\hline 3UU3_C & 40 & 0.0007 & $24 \%$ & $42 \%$ & $7 \%$ & 3.15 \\
\hline 3UU3_D & 40 & 0.0007 & $24 \%$ & $42 \%$ & $7 \%$ & 3.15 \\
\hline 3UU3_E & 40 & 0.0007 & $24 \%$ & $42 \%$ & $7 \%$ & 3.15 \\
\hline 2XQ9_A & 42.7 & $8.60 \mathrm{E}-05$ & $24 \%$ & $43 \%$ & $7 \%$ & 3.2 \\
\hline 2XQ9_B & 42.7 & $8.60 \mathrm{E}-05$ & $24 \%$ & $43 \%$ & $7 \%$ & 3.2 \\
\hline 2XQ9_C & 42.7 & $8.60 \mathrm{E}-05$ & $24 \%$ & $43 \%$ & $7 \%$ & 3.2 \\
\hline
\end{tabular}




\section{Continued}

\begin{tabular}{|c|c|c|c|c|c|c|}
\hline 2XQ9_D & 42.7 & $8.60 \mathrm{E}-05$ & $24 \%$ & $43 \%$ & $7 \%$ & 3.2 \\
\hline 2XQ9_E & 42.7 & $8.60 \mathrm{E}-05$ & $24 \%$ & $43 \%$ & $7 \%$ & 3.2 \\
\hline 3P4W_A & 42.7 & $8.60 \mathrm{E}-05$ & $24 \%$ & $43 \%$ & $7 \%$ & 3.2 \\
\hline 3P4W_B & 42.7 & $8.60 \mathrm{E}-05$ & $24 \%$ & $43 \%$ & $7 \%$ & 3.2 \\
\hline 3P4W_C & 42.7 & $8.60 \mathrm{E}-05$ & $24 \%$ & $43 \%$ & $7 \%$ & 3.2 \\
\hline 3P4W_D & 42.7 & $8.60 \mathrm{E}-05$ & $24 \%$ & $43 \%$ & $7 \%$ & 3.2 \\
\hline 3P4W_E & 42.7 & $8.60 \mathrm{E}-05$ & $24 \%$ & $43 \%$ & $7 \%$ & 3.2 \\
\hline 3TLS_A & 42.7 & $9.00 \mathrm{E}-05$ & $24 \%$ & $43 \%$ & $7 \%$ & 3.2 \\
\hline 3TLS_B & 42.7 & $9.00 \mathrm{E}-05$ & $24 \%$ & $43 \%$ & $7 \%$ & 3.2 \\
\hline 3TLS_C & 42.7 & $9.00 \mathrm{E}-05$ & $24 \%$ & $43 \%$ & $7 \%$ & 3.2 \\
\hline 3TLS_D & 42.7 & $9.00 \mathrm{E}-05$ & $24 \%$ & $43 \%$ & $7 \%$ & 3.2 \\
\hline 3TLS_E & 42.7 & $9.00 \mathrm{E}-05$ & $24 \%$ & $43 \%$ & $7 \%$ & 3.2 \\
\hline 4AFT_A & 63.9 & $1.50 \mathrm{E}-12$ & $25 \%$ & $45 \%$ & $4 \%$ & 3.2 \\
\hline 4AFT_B & 63.9 & $1.50 \mathrm{E}-12$ & $25 \%$ & $45 \%$ & $4 \%$ & 3.2 \\
\hline 4AFT_C & 63.9 & $1.50 \mathrm{E}-12$ & $25 \%$ & $45 \%$ & $4 \%$ & 3.2 \\
\hline 4AFT_D & 63.9 & $1.50 \mathrm{E}-12$ & $25 \%$ & $45 \%$ & $4 \%$ & 3.2 \\
\hline 4AFT_E & 63.9 & $1.50 \mathrm{E}-12$ & $25 \%$ & $45 \%$ & $4 \%$ & 3.2 \\
\hline 2XNT_A & 63.5 & $2.80 \mathrm{E}-12$ & $24 \%$ & $44 \%$ & $4 \%$ & 3.21 \\
\hline 2XNT_B & 63.5 & $2.80 \mathrm{E}-12$ & $24 \%$ & $44 \%$ & $4 \%$ & 3.21 \\
\hline 2XNT_C & 63.5 & $2.80 \mathrm{E}-12$ & $24 \%$ & $44 \%$ & $4 \%$ & 3.21 \\
\hline 2XNT_D & 63.5 & $2.80 \mathrm{E}-12$ & $24 \%$ & $44 \%$ & $4 \%$ & 3.21 \\
\hline 2XNT_E & 63.5 & $2.80 \mathrm{E}-12$ & $24 \%$ & $44 \%$ & $4 \%$ & 3.21 \\
\hline 2XNT_F & 63.5 & $2.80 \mathrm{E}-12$ & $24 \%$ & $44 \%$ & $4 \%$ & 3.21 \\
\hline 2XNT_G & 63.5 & $2.80 \mathrm{E}-12$ & $24 \%$ & $44 \%$ & $4 \%$ & 3.21 \\
\hline 2XNT_H & 63.5 & $2.80 \mathrm{E}-12$ & $24 \%$ & $44 \%$ & $4 \%$ & 3.21 \\
\hline 2XNT_I & 63.5 & $2.80 \mathrm{E}-12$ & $24 \%$ & $44 \%$ & $4 \%$ & 3.21 \\
\hline 2XNT_J & 63.5 & $2.80 \mathrm{E}-12$ & $24 \%$ & $44 \%$ & $4 \%$ & 3.21 \\
\hline 3UU8_A & 40 & 0.00074 & $24 \%$ & $42 \%$ & $7 \%$ & 3.25 \\
\hline 3UU8_B & 40 & 0.00074 & $24 \%$ & $42 \%$ & $7 \%$ & 3.25 \\
\hline 3UU8_C & 40 & 0.00074 & $24 \%$ & $42 \%$ & $7 \%$ & 3.25 \\
\hline 3UU8_D & 40 & 0.00074 & $24 \%$ & $42 \%$ & $7 \%$ & 3.25 \\
\hline 3UU8_E & 40 & 0.00074 & $24 \%$ & $42 \%$ & $7 \%$ & 3.25 \\
\hline 2Y58_A & 63.9 & $1.50 \mathrm{E}-12$ & $25 \%$ & $45 \%$ & $4 \%$ & 3.25 \\
\hline 2Y58_B & 63.9 & $1.50 \mathrm{E}-12$ & $25 \%$ & $45 \%$ & $4 \%$ & 3.25 \\
\hline 2Y58_C & 63.9 & $1.50 \mathrm{E}-12$ & $25 \%$ & $45 \%$ & $4 \%$ & 3.25 \\
\hline 2Y58_D & 63.9 & $1.50 \mathrm{E}-12$ & $25 \%$ & $45 \%$ & $4 \%$ & 3.25 \\
\hline 2Y58_E & 63.9 & $1.50 \mathrm{E}-12$ & $25 \%$ & $45 \%$ & $4 \%$ & 3.25 \\
\hline
\end{tabular}




\section{Continued}

\begin{tabular}{|c|c|c|c|c|c|c|}
\hline 3RHW_A & 46.2 & $6.90 \mathrm{E}-06$ & $22 \%$ & $44 \%$ & $4 \%$ & 3.26 \\
\hline 3RHW_B & 46.2 & $6.90 \mathrm{E}-06$ & $22 \%$ & $44 \%$ & $4 \%$ & 3.26 \\
\hline 3RHW_C & 46.2 & $6.90 \mathrm{E}-06$ & $22 \%$ & $44 \%$ & $4 \%$ & 3.26 \\
\hline 3RHW_D & 46.2 & $6.90 \mathrm{E}-06$ & $22 \%$ & $44 \%$ & $4 \%$ & 3.26 \\
\hline 3RHW_E & 46.2 & $6.90 \mathrm{E}-06$ & $22 \%$ & $44 \%$ & $4 \%$ & 3.26 \\
\hline 2VL0_A & 27.3 & 9.7 & $18 \%$ & $42 \%$ & $10 \%$ & 3.3 \\
\hline 2VL0_B & 27.3 & 9.7 & $18 \%$ & $42 \%$ & $10 \%$ & 3.3 \\
\hline 2VL0_C & 27.3 & 9.7 & $18 \%$ & $42 \%$ & $10 \%$ & 3.3 \\
\hline 2VL0_D & 27.3 & 9.7 & $18 \%$ & $42 \%$ & $10 \%$ & 3.3 \\
\hline 2VL0_E & 27.3 & 9.7 & $18 \%$ & $42 \%$ & $10 \%$ & 3.3 \\
\hline 2VL0_F & 27.3 & 9.7 & $18 \%$ & $42 \%$ & $10 \%$ & 3.3 \\
\hline 2VL0_G & 27.3 & 9.7 & $18 \%$ & $42 \%$ & $10 \%$ & 3.3 \\
\hline 2VL0_H & 27.3 & 9.7 & $18 \%$ & $42 \%$ & $10 \%$ & 3.3 \\
\hline 2VL0_I & 27.3 & 9.7 & $18 \%$ & $42 \%$ & $10 \%$ & 3.3 \\
\hline 2VL0_J & 27.3 & 9.7 & $18 \%$ & $42 \%$ & $10 \%$ & 3.3 \\
\hline 2YKS_A & 27.3 & 9.8 & $18 \%$ & $42 \%$ & $10 \%$ & 3.3 \\
\hline 2YKS_B & 27.3 & 9.8 & $18 \%$ & $42 \%$ & $10 \%$ & 3.3 \\
\hline 2YKS_C & 27.3 & 9.8 & $18 \%$ & $42 \%$ & $10 \%$ & 3.3 \\
\hline 2YKS_D & 27.3 & 9.8 & $18 \%$ & $42 \%$ & $10 \%$ & 3.3 \\
\hline 2YKS_E & 27.3 & 9.8 & $18 \%$ & $42 \%$ & $10 \%$ & 3.3 \\
\hline 2YKS_F & 27.3 & 9.8 & $18 \%$ & $42 \%$ & $10 \%$ & 3.3 \\
\hline 2YKS_G & 27.3 & 9.8 & $18 \%$ & $42 \%$ & $10 \%$ & 3.3 \\
\hline 2YKS_H & 27.3 & 9.8 & $18 \%$ & $42 \%$ & $10 \%$ & 3.3 \\
\hline 2YKS_I & 27.3 & 9.8 & $18 \%$ & $42 \%$ & $10 \%$ & 3.3 \\
\hline 2YKS_J & 27.3 & 9.8 & $18 \%$ & $42 \%$ & $10 \%$ & 3.3 \\
\hline 3P50_A & 42.7 & $8.60 \mathrm{E}-05$ & $24 \%$ & $43 \%$ & $7 \%$ & 3.3 \\
\hline 3P50_B & 42.7 & $8.60 \mathrm{E}-05$ & $24 \%$ & $43 \%$ & $7 \%$ & 3.3 \\
\hline 3P50_C & 42.7 & $8.60 \mathrm{E}-05$ & $24 \%$ & $43 \%$ & $7 \%$ & 3.3 \\
\hline 3P50_D & 42.7 & $8.60 \mathrm{E}-05$ & $24 \%$ & $43 \%$ & $7 \%$ & 3.3 \\
\hline 3P50_E & 42.7 & $8.60 \mathrm{E}-05$ & $24 \%$ & $43 \%$ & $7 \%$ & 3.3 \\
\hline 3TLT_A & 42.7 & 0.0001 & $24 \%$ & $43 \%$ & $7 \%$ & 3.3 \\
\hline 3TLT_B & 42.7 & 0.0001 & $24 \%$ & $43 \%$ & $7 \%$ & 3.3 \\
\hline 3TLT_C & 42.7 & 0.0001 & $24 \%$ & $43 \%$ & $7 \%$ & 3.3 \\
\hline 3TLT_D & 42.7 & 0.0001 & $24 \%$ & $43 \%$ & $7 \%$ & 3.3 \\
\hline 3TLT_E & 42.7 & 0.0001 & $24 \%$ & $43 \%$ & $7 \%$ & 3.3 \\
\hline 2Y57_A & 63.9 & $1.50 \mathrm{E}-12$ & $25 \%$ & $45 \%$ & $4 \%$ & 3.3 \\
\hline 2Y57_B & 63.9 & $1.50 \mathrm{E}-12$ & $25 \%$ & $45 \%$ & $4 \%$ & 3.3 \\
\hline
\end{tabular}




\section{Continued}

\begin{tabular}{|c|c|c|c|c|c|c|}
\hline 2Y57_C & 63.9 & $1.50 \mathrm{E}-12$ & $25 \%$ & $45 \%$ & $4 \%$ & 3.3 \\
\hline 2Y57_D & 63.9 & $1.50 \mathrm{E}-12$ & $25 \%$ & $45 \%$ & $4 \%$ & 3.3 \\
\hline 2Y57_E & 63.9 & $1.50 \mathrm{E}-12$ & $25 \%$ & $45 \%$ & $4 \%$ & 3.3 \\
\hline 2YN6_A & 27.3 & 9 & $18 \%$ & $42 \%$ & $10 \%$ & 3.31 \\
\hline 2YN6_B & 27.3 & 9 & $18 \%$ & $42 \%$ & $10 \%$ & 3.31 \\
\hline 2YN6_C & 27.3 & 9 & $18 \%$ & $42 \%$ & $10 \%$ & 3.31 \\
\hline 2YN6_D & 27.3 & 9 & $18 \%$ & $42 \%$ & $10 \%$ & 3.31 \\
\hline 2YN6_E & 27.3 & 9 & $18 \%$ & $42 \%$ & $10 \%$ & 3.31 \\
\hline 3RIF_A & 46.2 & $6.90 \mathrm{E}-06$ & $22 \%$ & $44 \%$ & $4 \%$ & 3.35 \\
\hline 3RIF_B & 46.2 & $6.90 \mathrm{E}-06$ & $22 \%$ & $44 \%$ & $4 \%$ & 3.35 \\
\hline 3RIF_C & 46.2 & $6.90 \mathrm{E}-06$ & $22 \%$ & $44 \%$ & $4 \%$ & 3.35 \\
\hline 3RIF_D & 46.2 & $6.90 \mathrm{E}-06$ & $22 \%$ & $44 \%$ & $4 \%$ & 3.35 \\
\hline 3RIF_E & 46.2 & $6.90 \mathrm{E}-06$ & $22 \%$ & $44 \%$ & $4 \%$ & 3.35 \\
\hline 3RI5_A & 46.2 & $6.90 \mathrm{E}-06$ & $22 \%$ & $44 \%$ & $4 \%$ & 3.4 \\
\hline 3RI5_B & 46.2 & $6.90 \mathrm{E}-06$ & $22 \%$ & $44 \%$ & $4 \%$ & 3.4 \\
\hline 3RI5_C & 46.2 & $6.90 \mathrm{E}-06$ & $22 \%$ & $44 \%$ & $4 \%$ & 3.4 \\
\hline 3RI5_D & 46.2 & $6.90 \mathrm{E}-06$ & $22 \%$ & $44 \%$ & $4 \%$ & 3.4 \\
\hline 3RI5_E & 46.2 & $6.90 \mathrm{E}-06$ & $22 \%$ & $44 \%$ & $4 \%$ & 3.4 \\
\hline 2BYQ_A & 63.5 & $2.60 \mathrm{E}-12$ & $24 \%$ & $44 \%$ & $4 \%$ & 3.4 \\
\hline 2BYQ_B & 63.5 & $2.60 \mathrm{E}-12$ & $24 \%$ & $44 \%$ & $4 \%$ & 3.4 \\
\hline 2BYQ_C & 63.5 & $2.60 \mathrm{E}-12$ & $24 \%$ & $44 \%$ & $4 \%$ & 3.4 \\
\hline 2BYQ_D & 63.5 & $2.60 \mathrm{E}-12$ & $24 \%$ & $44 \%$ & $4 \%$ & 3.4 \\
\hline 2BYQ_E & 63.5 & $2.60 \mathrm{E}-12$ & $24 \%$ & $44 \%$ & $4 \%$ & 3.4 \\
\hline 2XQ7_A & 42.7 & $8.70 \mathrm{E}-05$ & $24 \%$ & $43 \%$ & $7 \%$ & 3.4 \\
\hline 2XQ7_B & 42.7 & $8.70 \mathrm{E}-05$ & $24 \%$ & $43 \%$ & $7 \%$ & 3.4 \\
\hline 2XQ7_C & 42.7 & $8.70 \mathrm{E}-05$ & $24 \%$ & $43 \%$ & $7 \%$ & 3.4 \\
\hline 2XQ7_D & 42.7 & $8.70 \mathrm{E}-05$ & $24 \%$ & $43 \%$ & $7 \%$ & 3.4 \\
\hline 2XQ7_E & 42.7 & $8.70 \mathrm{E}-05$ & $24 \%$ & $43 \%$ & $7 \%$ & 3.4 \\
\hline 3UQ4_A & 27.3 & 8.9 & $18 \%$ & $42 \%$ & $10 \%$ & 3.5 \\
\hline 3UQ4_B & 27.3 & 8.9 & $18 \%$ & $42 \%$ & $10 \%$ & 3.5 \\
\hline 3UQ4_C & 27.3 & 8.9 & $18 \%$ & $42 \%$ & $10 \%$ & 3.5 \\
\hline 3UQ4_D & 27.3 & 8.9 & $18 \%$ & $42 \%$ & $10 \%$ & 3.5 \\
\hline 3UQ4_E & 27.3 & 8.9 & $18 \%$ & $42 \%$ & $10 \%$ & 3.5 \\
\hline 3UQ4_F & 27.3 & 8.9 & $18 \%$ & $42 \%$ & $10 \%$ & 3.5 \\
\hline 3UQ4_G & 27.3 & 8.9 & $18 \%$ & $42 \%$ & $10 \%$ & 3.5 \\
\hline 3UQ4_H & 27.3 & 8.9 & $18 \%$ & $42 \%$ & $10 \%$ & 3.5 \\
\hline 3UQ4_I & 27.3 & 8.9 & $18 \%$ & $42 \%$ & $10 \%$ & 3.5 \\
\hline
\end{tabular}




\section{Continued}

\begin{tabular}{|c|c|c|c|c|c|c|}
\hline 3UQ4_J & 27.3 & 8.9 & $18 \%$ & $42 \%$ & $10 \%$ & 3.5 \\
\hline 2XQ3_A & 42.7 & $8.70 \mathrm{E}-05$ & $24 \%$ & $43 \%$ & $7 \%$ & 3.5 \\
\hline 2XQ3_B & 42.7 & $8.70 \mathrm{E}-05$ & $24 \%$ & $43 \%$ & $7 \%$ & 3.5 \\
\hline 2XQ3_C & 42.7 & $8.70 \mathrm{E}-05$ & $24 \%$ & $43 \%$ & $7 \%$ & 3.5 \\
\hline 2XQ3_D & 42.7 & $8.70 \mathrm{E}-05$ & $24 \%$ & $43 \%$ & $7 \%$ & 3.5 \\
\hline 2XQ3_E & 42.7 & $8.70 \mathrm{E}-05$ & $24 \%$ & $43 \%$ & $7 \%$ & 3.5 \\
\hline 2XQ5_A & 42.7 & $8.70 \mathrm{E}-05$ & $24 \%$ & $43 \%$ & $7 \%$ & 3.5 \\
\hline 2XQ5_B & 42.7 & $8.70 \mathrm{E}-05$ & $24 \%$ & $43 \%$ & $7 \%$ & 3.5 \\
\hline 2XQ5_C & 42.7 & $8.70 \mathrm{E}-05$ & $24 \%$ & $43 \%$ & $7 \%$ & 3.5 \\
\hline 2XQ5_D & 42.7 & $8.70 \mathrm{E}-05$ & $24 \%$ & $43 \%$ & $7 \%$ & 3.5 \\
\hline 2XQ5_E & 42.7 & $8.70 \mathrm{E}-05$ & $24 \%$ & $43 \%$ & $7 \%$ & 3.5 \\
\hline 3EI0_A & 42.7 & $9.00 \mathrm{E}-05$ & $24 \%$ & $43 \%$ & $7 \%$ & 3.5 \\
\hline 3EI0_B & 42.7 & $9.00 \mathrm{E}-05$ & $24 \%$ & $43 \%$ & $7 \%$ & 3.5 \\
\hline 3EI0_C & 42.7 & $9.00 \mathrm{E}-05$ & $24 \%$ & $43 \%$ & $7 \%$ & 3.5 \\
\hline 3EI0_D & 42.7 & $9.00 \mathrm{E}-05$ & $24 \%$ & $43 \%$ & $7 \%$ & 3.5 \\
\hline 3EI0_E & 42.7 & $9.00 \mathrm{E}-05$ & $24 \%$ & $43 \%$ & $7 \%$ & 3.5 \\
\hline 2Y56_A & 63.9 & $1.50 \mathrm{E}-12$ & $25 \%$ & $45 \%$ & $4 \%$ & 3.59 \\
\hline 2Y56_B & 63.9 & $1.50 \mathrm{E}-12$ & $25 \%$ & $45 \%$ & $4 \%$ & 3.59 \\
\hline 2Y56_C & 63.9 & $1.50 \mathrm{E}-12$ & $25 \%$ & $45 \%$ & $4 \%$ & 3.59 \\
\hline 2Y56_D & 63.9 & $1.50 \mathrm{E}-12$ & $25 \%$ & $45 \%$ & $4 \%$ & 3.59 \\
\hline 2Y56_E & 63.9 & $1.50 \mathrm{E}-12$ & $25 \%$ & $45 \%$ & $4 \%$ & 3.59 \\
\hline 2XQ4_A & 42.7 & $8.70 \mathrm{E}-05$ & $24 \%$ & $43 \%$ & $7 \%$ & 3.6 \\
\hline 2XQ4_B & 42.7 & $8.70 \mathrm{E}-05$ & $24 \%$ & $43 \%$ & $7 \%$ & 3.6 \\
\hline 2XQ4_C & 42.7 & $8.70 \mathrm{E}-05$ & $24 \%$ & $43 \%$ & $7 \%$ & 3.6 \\
\hline 2XQ4_D & 42.7 & $8.70 \mathrm{E}-05$ & $24 \%$ & $43 \%$ & $7 \%$ & 3.6 \\
\hline 2XQ4_E & 42.7 & $8.70 \mathrm{E}-05$ & $24 \%$ & $43 \%$ & $7 \%$ & 3.6 \\
\hline 2XQ8_A & 42.7 & $8.70 \mathrm{E}-05$ & $24 \%$ & $43 \%$ & $7 \%$ & 3.6 \\
\hline 2XQ8_B & 42.7 & $8.70 \mathrm{E}-05$ & $24 \%$ & $43 \%$ & $7 \%$ & 3.6 \\
\hline 2XQ8_C & 42.7 & $8.70 \mathrm{E}-05$ & $24 \%$ & $43 \%$ & $7 \%$ & 3.6 \\
\hline 2XQ8_D & 42.7 & $8.70 \mathrm{E}-05$ & $24 \%$ & $43 \%$ & $7 \%$ & 3.6 \\
\hline 2XQ8_E & 42.7 & $8.70 \mathrm{E}-05$ & $24 \%$ & $43 \%$ & $7 \%$ & 3.6 \\
\hline 2Y54_A & 63.9 & $1.50 \mathrm{E}-12$ & $25 \%$ & $45 \%$ & $4 \%$ & 3.65 \\
\hline 2Y54_B & 63.9 & $1.50 \mathrm{E}-12$ & $25 \%$ & $45 \%$ & $4 \%$ & 3.65 \\
\hline 2Y54_C & 63.9 & $1.50 \mathrm{E}-12$ & $25 \%$ & $45 \%$ & $4 \%$ & 3.65 \\
\hline
\end{tabular}




\section{Continued}

\begin{tabular}{|c|c|c|c|c|c|c|}
\hline 2Y54_D & 63.9 & $1.50 \mathrm{E}-12$ & $25 \%$ & $45 \%$ & $4 \%$ & 3.65 \\
\hline 2Y54_E & 63.9 & $1.50 \mathrm{E}-12$ & $25 \%$ & $45 \%$ & $4 \%$ & 3.65 \\
\hline 2XQ6_A & 42.7 & $8.70 \mathrm{E}-05$ & $24 \%$ & $43 \%$ & $7 \%$ & 3.7 \\
\hline 2XQ6_B & 42.7 & $8.70 \mathrm{E}-05$ & $24 \%$ & $43 \%$ & $7 \%$ & 3.7 \\
\hline 2XQ6_C & 42.7 & $8.70 \mathrm{E}-05$ & $24 \%$ & $43 \%$ & $7 \%$ & 3.7 \\
\hline 2XQ6_D & 42.7 & $8.70 \mathrm{E}-05$ & $24 \%$ & $43 \%$ & $7 \%$ & 3.7 \\
\hline 2XQ6_E & 42.7 & $8.70 \mathrm{E}-05$ & $24 \%$ & $43 \%$ & $7 \%$ & 3.7 \\
\hline 2XQA_A & 42.7 & $8.70 \mathrm{E}-05$ & $24 \%$ & $43 \%$ & $7 \%$ & 3.7 \\
\hline 2XQA_B & 42.7 & $8.70 \mathrm{E}-05$ & $24 \%$ & $43 \%$ & $7 \%$ & 3.7 \\
\hline 2XQA_C & 42.7 & $8.70 \mathrm{E}-05$ & $24 \%$ & $43 \%$ & $7 \%$ & 3.7 \\
\hline 2XQA_D & 42.7 & $8.70 \mathrm{E}-05$ & $24 \%$ & $43 \%$ & $7 \%$ & 3.7 \\
\hline 2XQA_E & 42.7 & $8.70 \mathrm{E}-05$ & $24 \%$ & $43 \%$ & $7 \%$ & 3.7 \\
\hline 3UQ7_A & 27.3 & 9.4 & $18 \%$ & $42 \%$ & $10 \%$ & 3.8 \\
\hline 3UQ7_B & 27.3 & 9.4 & $18 \%$ & $42 \%$ & $10 \%$ & 3.8 \\
\hline 3UQ7_C & 27.3 & 9.4 & $18 \%$ & $42 \%$ & $10 \%$ & 3.8 \\
\hline 3UQ7_D & 27.3 & 9.4 & $18 \%$ & $42 \%$ & $10 \%$ & 3.8 \\
\hline 3UQ7_E & 27.3 & 9.4 & $18 \%$ & $42 \%$ & $10 \%$ & 3.8 \\
\hline 3UQ7_F & 27.3 & 9.4 & $18 \%$ & $42 \%$ & $10 \%$ & 3.8 \\
\hline 3UQ7_G & 27.3 & 9.4 & $18 \%$ & $42 \%$ & $10 \%$ & 3.8 \\
\hline 3UQ7_H & 27.3 & 9.4 & $18 \%$ & $42 \%$ & $10 \%$ & 3.8 \\
\hline 3UQ7_I & 27.3 & 9.4 & $18 \%$ & $42 \%$ & $10 \%$ & 3.8 \\
\hline 3UQ7_J & 27.3 & 9.4 & $18 \%$ & $42 \%$ & $10 \%$ & 3.8 \\
\hline 3RIA_A & 46.2 & $6.90 \mathrm{E}-06$ & $22 \%$ & $44 \%$ & $4 \%$ & 3.8 \\
\hline 3RIA_B & 46.2 & $6.90 \mathrm{E}-06$ & $22 \%$ & $44 \%$ & $4 \%$ & 3.8 \\
\hline 3RIA_C & 46.2 & $6.90 \mathrm{E}-06$ & $22 \%$ & $44 \%$ & $4 \%$ & 3.8 \\
\hline 3RIA_D & 46.2 & $6.90 \mathrm{E}-06$ & $22 \%$ & $44 \%$ & $4 \%$ & 3.8 \\
\hline 3RIA_E & 46.2 & $6.90 \mathrm{E}-06$ & $22 \%$ & $44 \%$ & $4 \%$ & 3.8 \\
\hline 2BG9_B & 176.4 & $1.20 \mathrm{E}-52$ & $40 \%$ & $65 \%$ & $3 \%$ & 4 \\
\hline 2BG9_C & 191.4 & $2.00 \mathrm{E}-58$ & $42 \%$ & $65 \%$ & $5 \%$ & 4 \\
\hline 2BG9_A & 192.6 & $7.00 \mathrm{E}-59$ & $45 \%$ & $63 \%$ & $2 \%$ & 4 \\
\hline 2BG9_D & 192.6 & $7.00 \mathrm{E}-59$ & $45 \%$ & $63 \%$ & $2 \%$ & 4 \\
\hline 2BG9_E & 199.1 & $2.60 \mathrm{E}-61$ & $46 \%$ & $67 \%$ & $3 \%$ & 4 \\
\hline 3UQ5_A & 27.3 & 9.4 & $18 \%$ & $42 \%$ & $10 \%$ & 4.2 \\
\hline 3UQ5_B & 27.3 & 9.4 & $18 \%$ & $42 \%$ & $10 \%$ & 4.2 \\
\hline
\end{tabular}




\section{Continued}

\begin{tabular}{|c|c|c|c|c|c|c|}
\hline 3UQ5_C & 27.3 & 9.4 & $18 \%$ & $42 \%$ & $10 \%$ & 4.2 \\
\hline 3UQ5_D & 27.3 & 9.4 & $18 \%$ & $42 \%$ & $10 \%$ & 4.2 \\
\hline 3UQ5_E & 27.3 & 9.4 & $18 \%$ & $42 \%$ & $10 \%$ & 4.2 \\
\hline 3UQ5_F & 27.3 & 9.4 & $18 \%$ & $42 \%$ & $10 \%$ & 4.2 \\
\hline 3UQ5_G & 27.3 & 9.4 & $18 \%$ & $42 \%$ & $10 \%$ & 4.2 \\
\hline 3UQ5_H & 27.3 & 9.4 & $18 \%$ & $42 \%$ & $10 \%$ & 4.2 \\
\hline 3UQ5_I & 27.3 & 9.4 & $18 \%$ & $42 \%$ & $10 \%$ & 4.2 \\
\hline 3UQ5_J & 27.3 & 9.4 & $18 \%$ & $42 \%$ & $10 \%$ & 4.2 \\
\hline 1YI5_A & 44.3 & $2.20 \mathrm{E}-05$ & $24 \%$ & $40 \%$ & $3 \%$ & 4.2 \\
\hline 1YI5_B & 44.3 & $2.20 \mathrm{E}-05$ & $24 \%$ & $40 \%$ & $3 \%$ & 4.2 \\
\hline 1YI5_C & 44.3 & $2.20 \mathrm{E}-05$ & $24 \%$ & $40 \%$ & $3 \%$ & 4.2 \\
\hline 1YI5_D & 44.3 & $2.20 \mathrm{E}-05$ & $24 \%$ & $40 \%$ & $3 \%$ & 4.2 \\
\hline 1YI5_E & 44.3 & $2.20 \mathrm{E}-05$ & $24 \%$ & $40 \%$ & $3 \%$ & 4.2 \\
\hline 4AOE_A & 57.4 & $2.90 \mathrm{E}-10$ & $28 \%$ & $49 \%$ & $8 \%$ & 5.8 \\
\hline 4AOE_B & 57.4 & $2.90 \mathrm{E}-10$ & $28 \%$ & $49 \%$ & $8 \%$ & 5.8 \\
\hline 4AOE_C & 57.4 & $2.90 \mathrm{E}-10$ & $28 \%$ & $49 \%$ & $8 \%$ & 5.8 \\
\hline 4AOE_D & 57.4 & $2.90 \mathrm{E}-10$ & $28 \%$ & $49 \%$ & $8 \%$ & 5.8 \\
\hline 4AOE_E & 57.4 & $2.90 \mathrm{E}-10$ & $28 \%$ & $49 \%$ & $8 \%$ & 5.8 \\
\hline 4AOD_A & 55.1 & $2.20 \mathrm{E}-09$ & $24 \%$ & $44 \%$ & $6 \%$ & 6 \\
\hline 4AOD_B & 55.1 & $2.20 \mathrm{E}-09$ & $24 \%$ & $44 \%$ & $6 \%$ & 6 \\
\hline 4AOD_C & 55.1 & $2.20 \mathrm{E}-09$ & $24 \%$ & $44 \%$ & $6 \%$ & 6 \\
\hline 4AOD_D & 55.1 & $2.20 \mathrm{E}-09$ & $24 \%$ & $44 \%$ & $6 \%$ & 6 \\
\hline 4AOD_E & 55.1 & $2.20 \mathrm{E}-09$ & $24 \%$ & $44 \%$ & $6 \%$ & 6 \\
\hline 4AQ5_B & 173.7 & $1.10 \mathrm{E}-50$ & $39 \%$ & $62 \%$ & $5 \%$ & 6.2 \\
\hline 4AQ5_C & 188.3 & $7.60 \mathrm{E}-56$ & $39 \%$ & $62 \%$ & $7 \%$ & 6.2 \\
\hline 4AQ9_B & 173.7 & $1.10 \mathrm{E}-50$ & $39 \%$ & $62 \%$ & $5 \%$ & 6.2 \\
\hline 4AQ9_C & 188.3 & $7.60 \mathrm{E}-56$ & $39 \%$ & $62 \%$ & $7 \%$ & 6.2 \\
\hline 4AQ5_E & 198.4 & $7.00 \mathrm{E}-60$ & $44 \%$ & $65 \%$ & $6 \%$ & 6.2 \\
\hline 4AQ9_E & 198.4 & $7.00 \mathrm{E}-60$ & $44 \%$ & $65 \%$ & $6 \%$ & 6.2 \\
\hline 4AQ5_A & 192.6 & $5.50 \mathrm{E}-58$ & $45 \%$ & $63 \%$ & $2 \%$ & 6.2 \\
\hline 4AQ5_D & 192.6 & $5.50 \mathrm{E}-58$ & $45 \%$ & $63 \%$ & $2 \%$ & 6.2 \\
\hline 4AQ9_A & 192.6 & $5.50 \mathrm{E}-58$ & $45 \%$ & $63 \%$ & $2 \%$ & 6.2 \\
\hline 4AQ9_D & 192.6 & $5.50 \mathrm{E}-58$ & $45 \%$ & $63 \%$ & $2 \%$ & 6.2 \\
\hline
\end{tabular}




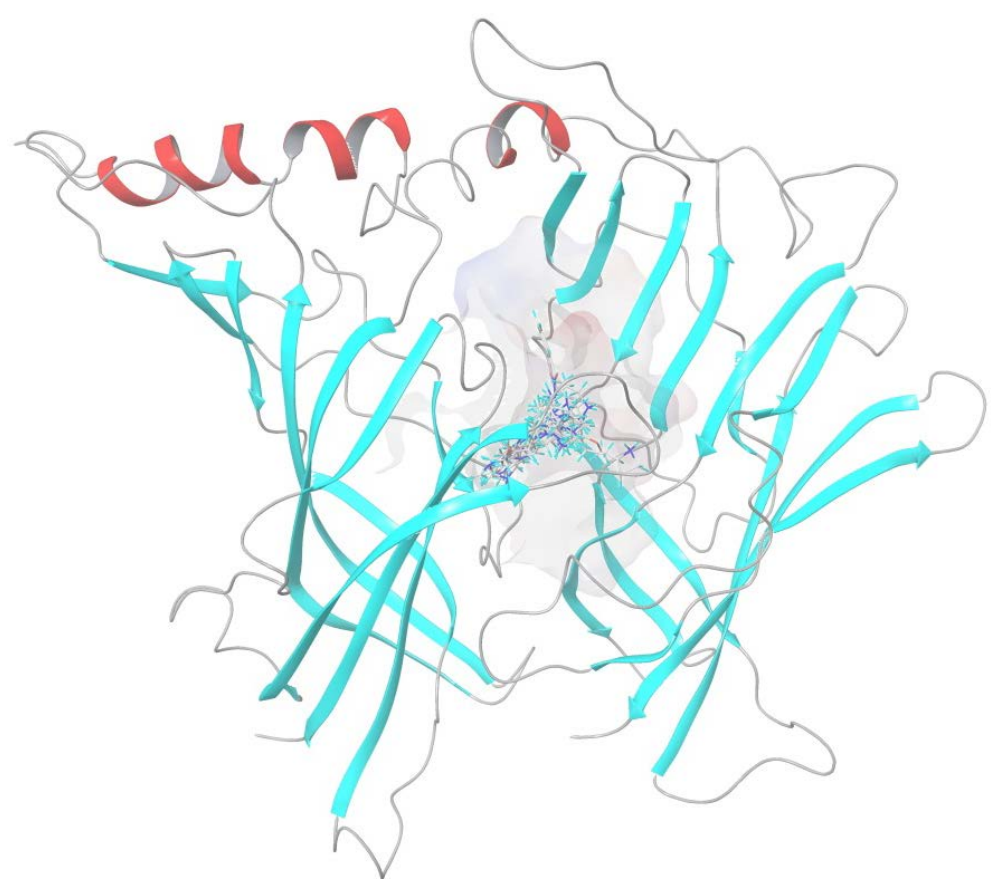

Figure S1. Docking poses of the 11 compounds in the homology model of human $\alpha 4 \beta 2$ nACHR. 